\title{
Does European Aflatoxin Regulation Hurt Groundnut Exporters from Africa?
}

\author{
Bo Xiong
}

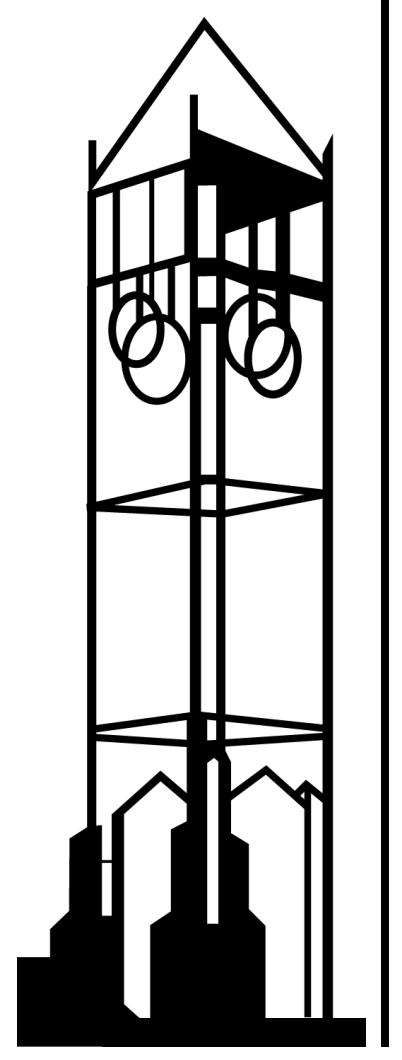

Working Paper No. 11026

February 2011

\section{IOWA STATE UNIVERSITY}

Department of Economics

Ames, lowa, 50011-1070 


\title{
Aflatoxin Redux: Does European Aflatoxin Regulation Hurt Groundnut Exporters from
}

\section{Africa?}

\author{
Bo Xiong \\ John Beghin* \\ Iowa State University \\ Revised February $1^{\text {st }}, 2011$
}

\begin{abstract}
We provide an ex-post econometric examination of the harmonization and tightening of the EU Maximum Residues Limit (MRL) on aflatoxins in 2002, and its impact on African exports of groundnut products. We show that the MRL set by the EU has no significant trade impact on groundnut exports from Africa across various methods of estimation. African domestic supply plays an important role in the determination of the volumes of trade and the propensity to trade. Our findings suggest that the trade potential of African groundnut exporters is more constrained by domestic supply issues rather than by limited market access.
\end{abstract}

Keywords: food safety, standards, aflatoxin, MRL, groundnut, Africa, EU, market access JEL Code: Q17, F13

\footnotetext{
* Contact author: Bo Xiong at bxiong@iastate.edu. Bo Xiong is a graduate student in Economics and John Beghin is Marlin Cole Professor of International Agricultural Economics, both in the Department of Economics, Iowa State University. The authors thank the editor and three anonymous referees for comments, John Wilson and Tsunehiro Otsuki for providing their original data set, Dominique van der Mensbrugghe for providing further data, and John Schroeter and workshop participants at Iowa State University for comments on an earlier draft. The usual disclaimer applies.
} 


\section{Introduction}

Aflatoxins are a group of toxic metabolites produced by certain fungi in agricultural commodities. They are commonly found in agricultural crops such as corn, peanuts, coconuts, cassava and their food and feed products. Scientific research shows that aflatoxin B1, M1, and G1 can cause various types of cancer in both animal species and humans. Evidence of acute aflatoxicosis in humans has been reported from many parts of the world with grim morbidity and mortality. ${ }^{1}$ Chronic intake of aflatoxin in animals can lead to poor food intake and weight loss.

Due to their demonstrated potent health effect to both animals and humans, aflatoxins regulations have received great attention in food policy design and debates. Although some good practice based on current scientific knowledge and technical improvements can effectively reduce the level of contamination, the entire elimination of the presence of aflatoxin in foodstuffs is not possible. Therefore, certain Maximum Residue Limits (MRLs) are commonly adopted as the policy instrument to control for aflatoxin contamination in the food supply. While tight MRLs on aflatoxins generate health benefits, they also induce various costs such as regulatory and administrative costs, compliance costs borne by producers, and plausible forgone trade revenues borne by some foreign exporters failing the MRLs.

The European Union (EU)’s harmonization of the MRLs on aflatoxins in 2002 has highlighted these tradeoffs and initiated a controversy. Prior to 2002, member countries in the EU set their MRLs individually (FAO (1995)). In April 2002, the EU formally adopted a unified MRL policy on aflatoxin contaminants (European Communities (2001) and (2002)). In December 2006, the EU modified the harmonized maximum levels for certain contaminants in foodstuffs, but the policy regarding aflatoxin remained (European Communities (2006)). The

\footnotetext{
${ }^{1}$ The syndrome of aflatoxicosis is characterized by vomiting, abdominal pain, pulmonary edema, convulsions, coma, and death with cerebral edema and fatty involvement of the liver, kidneys, and heart.
} 
harmonized EU aflatoxin standards, from several perspectives, have been more stringent than the Codex Alimentarius, which contains the international standards recommended by the Food and Agriculture Organization (FAO) and World Health Organization (WHO). First, the EU policy targets specific aflatoxin compounds. Not only the EU policy sets an MRL for the total aflatoxin level as Codex does, it also imposes an MRL on aflatoxin B1, which is the most toxic compound in the aflatoxin family. Second, the EU MRLs are much lower than Codex. Figure 1 illustrates EU's harmonization and its departure from Codex in setting MRLs on aflatoxin B1 for edible and shelled groundnuts products. The harmonization tightened the MRL for edible groundnuts and relaxed the MRL on shelled nuts significantly, except in Portugal, where it was much tightened. MRLs for oil were not harmonized, but Switzerland relaxed its MRL on oil in 2002.

Figure 1: European and Codex MRLs on aflatoxin B1 for three groundnut products

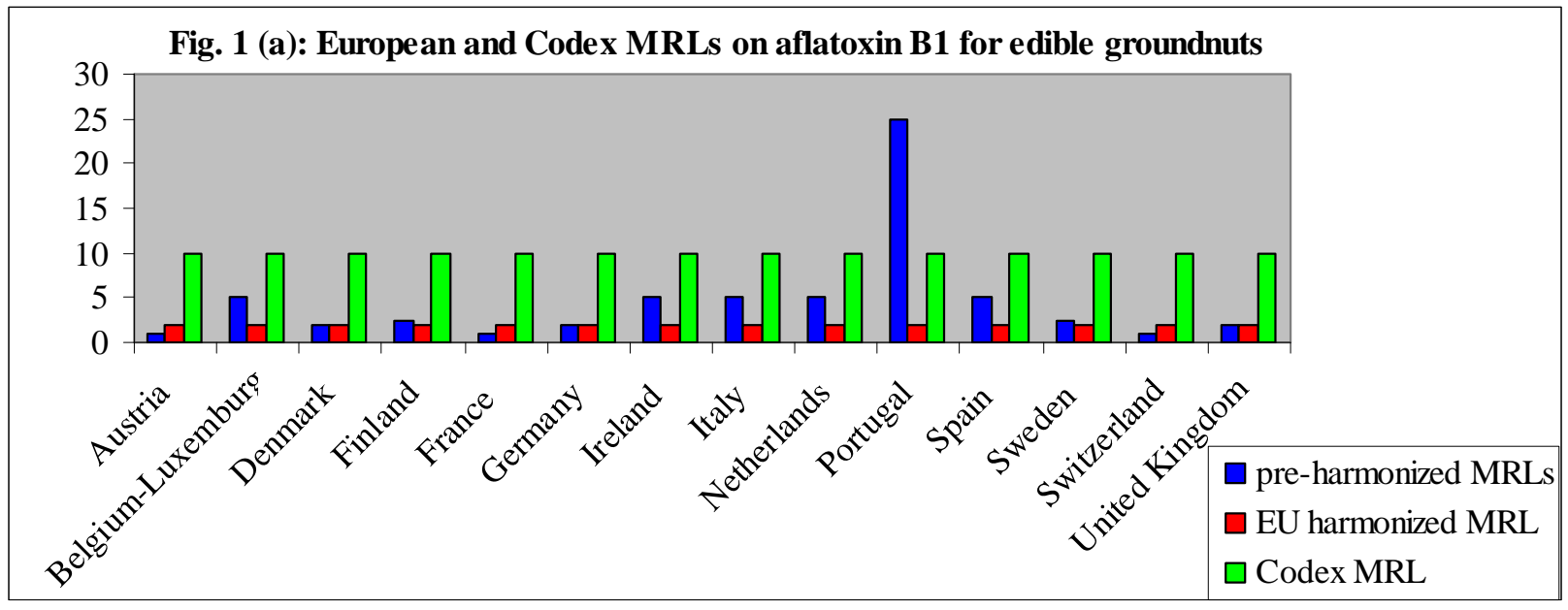



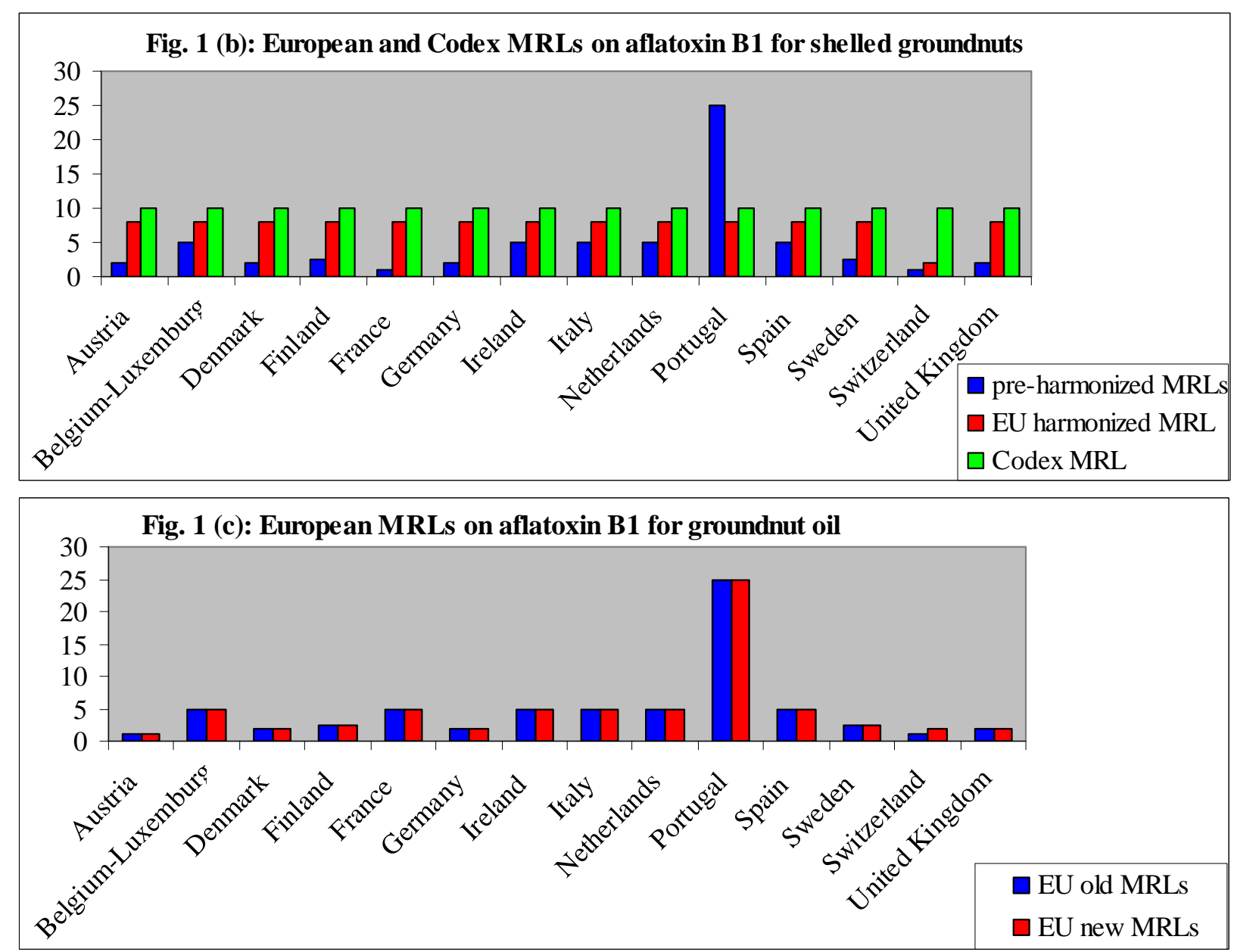

Notes: Data sources are FAO (1995), FAO (2004) and European Communities (2001) and (2002). Codex sets a MRL of $15 \mathrm{ppb}$ on total aflatoxin contaminants for edible groundnuts and shelled groundnuts. Science suggests that some $70 \%$ of the total aflatoxins can be attributed to Aflatoxin B1. Therefore, the Codex MRL on Aflatoxin B1 is roughly 10 ppb for both products. FAO (2004) shows that Switzerland, a non-EU member, has aligned itself on the EU 2- ppb MRL on aflatoxin B1 since 2002 for edible groundnuts.

The strictness of the EU standards has triggered concerns that the EU has abused the Agreements on Sanitary and Phytosanitary (SPS) Measures of the World Trade Organization (WTO) and created a protectionist SPS regulation. Groundnut exporters from Africa, in particular, are considered vulnerable to the new regulations because of their high cost of compliance and their dependency on the EU market as their largest export destination.

Otsuki, Wilson and Sewadeh (2001), in a noted paper, examined this very issue in the late 1990s by conducting a gravity equation analysis to a pre-harmonization dataset of EU MRLs and 
trade flows. They found that the African exports of edible groundnuts and groundnut oil were negatively affected by the MRL on aflatoxin set by EU member countries during 1989-1998. Their simulation predicted that the harmonization and tightening of the standards in 2002 would decrease African exports enormously. Notably, there are two limitations in this analysis. The first one is the lack of time-variation of the MRL variable. The research was done before the harmonization took place in 2002. During the period of examination, 1989-1998, the only available data source for the MRL policies on aflatoxin was FAO (1995), in which each country reported the MRL it currently imposed on aflatoxin contaminants. Consequently, the MRL observed for the single year had to be assumed to hold for the entire time period and only exhibited cross-sectional variation. As we will elaborate later, this lack of time-variation of the MRL variable makes its effect undistinguishable from the country-level "multilateral resistance" terms or fixed effects (Anderson and van Wincoop (2003)).

The second limitation in Otsuki et al. comes from their deletion of the zero trade records. Statistically, the elimination of zeros could result in the standard sample selection bias (Heckman (1979)). Even if the sample selection issue does not bias the estimate of interest, the ignorance of zero trade flows limits the economic interpretations of the model. First, the deletion of the zero trade precludes exploring the extensive margin of trade, that is, the creation of new bilateral trade partnership, and the role of MRL on this margin. In addition, all their estimates are conditioned on trade already taking place, and marginal effects of SPS measures and other trade costs are on the intensive margin of trade. Nothing could be said on implications for new trade.

The harmonized EU aflatoxin regulations have been effective for several years and these regulations remain a plausible factor contributing to the vulnerability of African groundnut export potential and market access. It is of much interest to reconsider the previous analysis and 
re-examine whether groundnut exporters from Africa actually turn out to be impeded by the new EU standards. This issue remains a major concern with development practitioners in particular. For example, IFPRI has several field projects funded by the Bill and Melinda Gates Foundation to explore the impact of aflatoxin MRLs on small African holders and new ways to overcome phytosanitary issues in production and trade (IFPRI (2009)). Our investigation complements this current fieldwork on aflatoxin and associated trade impediments.

Our analysis also contributes to the debate on Africa’s “under-trading” (Bouët, Mishra and Roy (2008)). Africa trades less with the rest of the world than one would expect, according to various economic models, even after controlling for major trade costs and the size of the trading economies. It remains a puzzle whether this African missing trade is more associated with the limited access to the world market or to domestic factors within Africa. For example, Bouët, Mishra and Roy (2008) incorporate various trade barriers in a gravity equation analysis and find that African countries in general already have good market access, and that the transport and communication infrastructure can be held accountable for the under-trading phenomenon. Other authors have emphasized the poor internal infrastructure of many African countries (Buys, Deichmann, and Wheeler (2010)).

The purpose of our study is to provide an ex-post econometric examination of the harmonization and tightening of EU MRLs on aflatoxins in 2002, and its impact on African exports of groundnut products. By virtue of a state-of-the-art gravity model with corrections for the sample selection bias, the 'multilateral resistance' terms, and the heterogeneity across firms, we show two main results. First, MRLs set by EU have no significant impact on groundnut exports from Africa across all preferred methods of estimation. Two rationalizations can help interpret this result. Either, the MRL regulations are non binding for African groundnut exporters 
because other factors in production and before the border are binding impediments. As discussed below, our second result favors this rationalization. Or, the alternative rationalization is that the tighter MRL on aflatoxin does induce additional trade costs to African groundnut exporters, but it also generates trade benefits because EU consumers value safer groundnut products from Africa. The two effects could offset each other, thus the net effect on trade is negligible.

The second result of our analysis is that domestic supply conditions in Africa play an important role in the determination of both the trade volumes and the propensity to trade in groundnut products. This result is consistent with the recent findings of Bouët et al. (2008) on the lack of trade facilitation in Sub-Saharan Africa for all exports, and the extent to which the missing trade is self-inflicted. Rios and Jaffee (2008) and Jaffee and Henson (2005) go one step further and point out that the proliferation and increased stringency of food safety standards can serve as a basis for the competitive repositioning of the developing world if developing countries successfully upgrade capacity and improve the operation of their supply chains (Maertens and Swinnen (2009)). Rios and Jaffee, and Jaffee and Henson also state that in several cases, inspections reveal extreme violations of MRL regulations by African exports, including violations of codex MRLs making the EU MRLs redundant. Consistent with the latter, our findings cast doubt on the conventional wisdom of restrictive EU aflatoxin regulations. They suggest the key importance of addressing domestic issues in production and trade facilitation in Africa. In terms of groundnut products, improving the farm-level practice could reduce the aflatoxin contaminants, increase yields, and eventually lead to more trade. These improvements would lead to more consistent production of exportable products which could meet the MRLs.

The analysis is organized into five sections. Section 2 outlines our empirical strategy and describes the data set. Section 3 presents the econometric models and the associated results. 
Section 4 conducts diagnostic analysis of competing models, checks the robustness of the main results, and summarizes the trade effects of the MRL policy. Section 5 concludes the presentation. An appendix is available from the authors with detailed results supplementing tables in the text.

\section{Methodology and Empirical Strategy}

Gravity equation models are widely used to infer trade flow effects of distance (Disdier and Head (2006)), currency union (Rose and van Wincoop (2001)), common borders (McCallum (1995)), tariffs (Baier and Bergstrand (2001)), technical barriers to trade (TBTs) (Maskus and Wilson (2001)), fixed trade cost between countries (Helpman, Melitz and Rubinstein (2008)), and other types of trade costs. The gravity equation approach posits that bilateral trade volume is a function of the importer's demand, the exporter's supply, and various bilateral trade costs such as tariffs, technical barriers, transportation costs, border effects, colonial ties, etc. One reason for its popularity lies in the fact that the gravity equation fits the data well across a wide range of applications in international trade. Despite its popularity, some recent research has raised concerns about several widespread mistakes and biases in gravity equation applications to trade (Anderson and van Wincoop (2003), Baldwin and Taglioni (2006), Helpman, Meltiz and Rubinstein (2008), and Martin and Pham (2008) among others).

One strand of the research focuses on the micro-foundations of the gravity equation model. Anderson and van Wincoop (2003) use a full expenditure system and market clearing conditions to derive a gravity equation with country-specific "multilateral resistance" terms, which are often omitted in traditional gravity equation specifications. Baldwin and Taglioni (2006) point out three mistakes, defined as golden, silver and bronze, often made in gravity 
equation applications. These include, the ignorance of 'gravitational un-constant term', which corresponds to the above-mentioned country-specific 'multilateral resistance' term; the mistake in averaging bilateral trade data; and the wrong deflators applied to GDP and trade series.

Further recent literature sheds light on several econometric problems associated with the gravity equation that are relevant to our analysis. The first problem is the sample selection bias, as originally defined by Heckman (1979). A commonly found feature in bilateral trade data is that zero trade records are frequent across country-pairs and products, and that the zero trade flows could dominate when disaggregated trade data are used. Martin and Pham (2008) show that failure in modeling such limited dependency of the trade data can result in large biases for all estimates of interest. Helpman, Melitz, and Rubinstein (2008) attribute the absence of trade to exporting firms' self-selection behavior. Accounting for heterogeneous productivity across firms, they establish a generalized gravity equation that accommodates asymmetric trade flows, zero trade observations, and the overlooked extensive margin from new firms entering export markets. The estimation of their generalized gravity equation model does not require firm level data and can be implemented via a two-stage modified Heckman procedure.

The second econometric problem associated with gravity equation models evolves around heteroscedasticity. Silva and Tenreyro (2006) point out that because of the Jensen's Inequality, the parameters of a log-linearized gravity equation can not be interpreted as the true elasticities. To circumvent this problem, they propose estimating the gravity equation model in its original multiplicative form in levels using a Poisson Pseudo-Maximum-Likelihood (PPML thereafter) method. Martin and Pham (2008) compare different estimators in a Monte-Carlo experiment in which both prevalence of zero trade and heteroscedasticity are present. Their results show that the Heckman Maximum Likelihood estimator performs well if true identifying restrictions are 
available, and that PPML solves the elasticity problem but yields biased estimates when zero trade observations are frequent. In an application to the exports of US corn seeds, Jayasinghe, Beghin and Moschini (2010) find that PPML does not accommodate pervasive zeros well.

Burger, Van Oort, and Linders (2009) suggest that some variants of the PPML estimator accommodate greater dispersion of the data than implied by the Poisson distribution and the presence of numerous zero observations using a "zero inflation equation.” These variants are the Negative Binomial Pseudo Maximum Likelihood estimator (NBPML thereafter), the ZeroInflated Poisson Pseudo Maximum Likelihood model (ZIPPML thereafter), and the Zero-Inflated Negative Binomial Pseudo Maximum Likelihood model (ZINBPML thereafter). These models often outperform PPML in empirical trade applications with frequent zero trade flows. The selection of a preferred estimator to address the co-existence of the pervasive zero trade flows and the heteroskedasticity issue is an empirical question. We apply different methods of estimation as explained later in section 4 with a model selection strategy. We consider Truncated Sample Ordinary Least Square, the Helpman-Melitz-Rubinstein (HMR) generalized gravity equation model, and the pseudo maximum likelihood estimators (PPML, NBPML, ZIPPML, and ZINBPML). Inferences are then drawn based on thorough statistical diagnostic analysis and comparison across all estimates in section 5, to develop a thorough assessment and select preferred estimates whenever possible.

\section{Data Description}

Our dataset builds upon the dataset of Otsuki et al. (2001). Three groundnut products are considered: edible groundnuts, groundnut oil, and shelled groundnut (groundnut for further processing). Bilateral trade volumes of each groundnut product between 14 European countries 
(13 EU members: Austria, Belgium-Luxemburg, Denmark, Finland, France, Germany, Ireland, Italy, Netherlands, Portugal, Spain, Sweden, plus Switzerland ${ }^{2}$ ), and nine African countries (Chad, Egypt, Gambia, Mali, Nigeria, Sudan, Senegal, South Africa, and Zimbabwe) are extracted from United Nations COMTRADE records for the period 1989-2006. ${ }^{3}$ For MRL levels, we use Food and Agriculture Organization (FAO)'s survey of worldwide regulations for mycotoxins in food and feed (FAO (1995)), and Commission Regulation No 466/2001 on setting maximum levels for certain contaminants in foodstuffs (European Commission (2001)). With these two sources, we construct an MRL variable that indicates the MRLs on aflatoxin B1 imposed by each EU member country in each year. ${ }^{4}$

The income argument in any EU member country’s demand for groundnut exports is represented by its GDP expressed in local currency units from the World Development Indicators of The World Bank for any given year. The annual domestic supply of a groundnut product in a given African country is proxied by its total exports of that product. ${ }^{5}$ To deal with the plausible endogeneity problem with this proxy, we also extract food supply series from FAOSTAT database for robustness’ check. Our dataset also contains a distance variable measuring the capital distances between country pairs, a colonial tie dummy indicating whether trading partners had colonial relationship in history as described in the original Otsuki et al.

\footnotetext{
${ }^{2}$ We refer to all 14 importers of interest as EU member countries or the EU hereafter including Switzerland which has aflatoxin MRLs similar to the EU MRLs but is not a member of the EU.

${ }^{3}$ SITC Revision 1 codes 05172, 2211 and 4214 are used as the product categories for edible groundnut, shelled groundnut and groundnut oil, respectively.

${ }^{4}$ Constrained by the data availability, we follow Otsuki et al. (2001) and assume that the MRLs reported in FAO (1995) hold for the period 1989-2001. The harmonized MRLs cover the period 2002-2006.

${ }^{5}$ Though it is desirable to add African domestic consumptions to the African supply proxy, the consumption data in Africa is not systematically available. Consumption is often made of lower quality groundnuts. We implicitly assume that domestic consumption only takes a negligible share of the supply of the high quality groundnut products in Africa since they are exportables.
} 
dataset, ${ }^{6}$ and a common language dummy that equals one if a language is spoken by at least $9 \%$ of the population in both countries.

Table 1 provides summary statistics for data of 3 sectors. Three features of our dataset are outstanding. First of all, zeros dominate the trade records in all three groundnut products. 88\% of the bilateral trade flows in edible groundnut between African countries and the EU are zeros. This percentage is $90 \%$ for groundnut oil and $81 \%$ for shelled groundnut. Some of these zero trade observations may be due to rounding errors or incompleteness of the COMTRADE, but many others are more likely to reflect African exporters’ reluctance or inability to trade. The latter could result from prohibitive fixed cost to establish trade partnership with the EU member countries, including compliance costs to meet the restrictive standards. Therefore, it is necessary to explicitly model this limited-dependency of the trade data to accommodate the absence of trade.

Table 1: Summary statistics

\begin{tabular}{|l|l|l|l|l|l|l|}
\hline Edible groundnuts & Obs & Mean & Std. Dev. & Min & Max & Unit \\
\hline Variable & 1736 & 0.011 & 0.061 & 0 & 1.237 & 1000 metric tons \\
\hline Trade & 1736 & 3.846 & 5.120 & 1 & 25 & parts per billion \\
\hline MRL & 1736 & 771.955 & 669.115 & 48.737 & 2660 & $\begin{array}{l}\text { billions of local } \\
\text { currency unit }\end{array}$ \\
\hline GDP_EU & 1736 & 1.323 & 2.616 & 0.0001 & 14.012 & 1000 metric ton \\
\hline Supply_Africa & 1736 & 5598.271 & 2182.47 & 2136.02 & 10489.44 & kilometers \\
\hline Distance & 17 & & & Max & Unit \\
\hline Shelled groundnuts & Obs & Mean & Std. Dev. & Min & Max \\
\hline Variable & Oble &
\end{tabular}

\footnotetext{
${ }^{6}$ Tariffs are other trade barriers. The TRAINS database shows that EU preferential tariff rates imposed on African countries are identically zero from 1995 on. Preferential tariff data prior to 1995 are not in TRAINS. The TARIC database contains some tariff information for some of the years between 1989 and 1995, showing not a single recorded tariff rate higher than 5\%. Therefore, we assume away the impact of tariffs on the groundnut trade between the EU and the African countries 1989-2006 given the lack of variation over time. Tariffs were also ignored by Otsuki et al. (2001).

${ }^{7}$ Although it is desirable to include the tariff schemes into the analysis, the bilateral tariffs on groundnut products before 1995 are unavailable from WITS. The available data after 1995 contain a large share of zeros (partially due to the agreements between EU and Africa such as EBAs) and exhibit little variation across the 14 importers. The time variation of the tariffs is captured by the time fixed effects. Therefore, the lack of tariffs should not bias the results.
} 


\begin{tabular}{|l|l|l|l|l|l|l|}
\hline Trade & 2156 & 0.275 & 1.293 & 0 & 20.651 & 1000 metric tons \\
\hline MRL & 2156 & 5.480 & 5.184 & 1 & 25 & parts per billion \\
\hline GDP_EU & 2156 & 770.618 & 668.833 & 48.737 & 2660 & $\begin{array}{l}\text { billions of local } \\
\text { currency unit }\end{array}$ \\
\hline Supply_Africa & 2156 & 7.867 & 10.816 & 0.0002 & 62.020 & 1000 metric ton \\
\hline Distance & 2156 & 5367.411 & 2041.899 & 2136.02 & 10489.44 & kilometers \\
\hline Groundnut oil & Obs & Mean & Std. Dev. & Min & Max & Unit \\
\hline Variable & 1470 & 1.130 & 5.879 & 0 & 96.594 & 1000 metric tons \\
\hline Trade & 1470 & 4.876 & 5.792 & 1 & 25 & parts per billion \\
\hline MRL & 1470 & 773.369 & 670.213 & 48.737 & 2660 & $\begin{array}{l}\text { billions of local } \\
\text { currency unit }\end{array}$ \\
\hline GDP_EU & 1470 & 17.168 & 30.280 & 0.0002 & 140.582 & 1000 metric ton \\
\hline Supply_Africa & 1470 & 5580.393 & 2093.681 & 2136.017 & 10489.44 & kilometers \\
\hline Distance & 1470 &
\end{tabular}

Second, the MRL variable exhibits time variation due to the EU harmonization of aflatoxin regulations in 2002, which allows us to disentangle the trade effect of the MRL policy out of the country-level fixed effects. Lastly, our supply proxy originates in the sectoral approach of the gravity equation and it is a supply measure in physical quantity rather than the GDP of the exporter. ${ }^{8}$ We express the supply in physical form (metric tons) rather than in dollars to avoid the problematic deflation issues raised by Baldwin and Taglioni (2006).

\section{Model Specifications and Results}

We consider three estimation strategies for the gravity equation model. The first one is the Truncated Sample Ordinary Least Square (Trun-OLS hereafter), which is most commonly used in the literature. It is an Ordinary Least Square estimator applied to a subsample that contains positive observations only. In our context, the associated gravity equation is specified as follows:

\footnotetext{
${ }^{8}$ We refer readers to Henry de Frahan and Vancauteren (2006) for a brief discussion of the sectoral gravity equation application to disaggregated trade data.
} 


$$
\begin{gathered}
\ln \left(Y_{i j t}^{k} \mid Y_{i j t}^{k}>0\right)=\beta_{0}^{k}+\beta_{1}^{k} \ln \left(M R L_{j t}^{k}\right)+\beta_{2}^{k} \ln \left(G D P_{j t}\right)+\beta_{3}^{k} \ln \left(\text { Supply }_{i t}^{k}\right)+\beta_{4}^{k} \ln \left(\text { Dist }_{i j}\right) \\
+\beta_{5}^{k} \text { Dlang }_{i j}+\sum_{t=1}^{18} \alpha_{t}^{k} \text { Year }_{t}+\sum_{m=1}^{8} \gamma_{m}^{k} \operatorname{Dex}_{m}+\sum_{n=1}^{13} \eta_{n}^{k} \operatorname{Dim}_{n}+\varepsilon_{i j t},
\end{gathered}
$$

where $\beta_{\mathrm{s}}, \alpha_{\mathrm{s}}, \gamma_{\mathrm{s}}$, and $\eta_{\mathrm{s}}$ are parameters to be estimated. A positive $\beta_{1}$ suggests that the MRL on aflatoxin is trade-impeding: the lower the tolerance level is, the less the bilateral trade flows are. $\varepsilon_{\mathrm{ijt}}$ is the classical idiosyncratic error term. The definition of each variable is presented in Table 2.

Table 2: Definitions of variables

\begin{tabular}{|c|l|}
\hline Variable Name & \multicolumn{1}{|c|}{ Definition } \\
\hline$Y_{i j t}^{k}$ & $\begin{array}{l}\text { The quantity traded of groundnut product } k \text { from African country } i \text { to } \\
\text { EU member country } j \text { in year } t\end{array}$ \\
\hline$M R L_{j t}^{k}$ & $\begin{array}{l}\text { The MRL applied to groundnut product } k \text { set by EU member country } j \\
\text { in year } t\end{array}$ \\
\hline$G D P_{j t}$ & The GDP (in local currency unit) of EU member country $j$ in year $t$ \\
\hline$S u p p l y_{i t}^{k}$ & The total supply of groundnut product $k$ in African country $i$ in year $t$ \\
\hline Dist $_{i j}$ & The distance between African country $i$ and EU member country $j$ \\
\hline Dlang $_{i j}$ & $\begin{array}{l}\text { The common language dummy variable for African country } i \text { and EU } \\
\text { member country } j\end{array}$ \\
\hline Year $_{t}$ & The dummy variable for year $t$ \\
\hline Dex $_{m}$ & The national dummy for African country $m^{\mathrm{a}, \mathrm{c}}$ \\
\hline Dim $_{n}$ & The national dummy for EU member country $n^{\mathrm{b}, \mathrm{c}}$ \\
\hline
\end{tabular}

Notes: a. South Africa is the reference country among the exporters whose national dummy is suppressed.

b.France is the reference country among importers whose national dummy is suppressed. c. Although time-varying national fixed effects are more desirable, the inclusion of time-varying importers' fixed effects would perfectly collinear with the MRL variable and fully absorb its effects.

We estimate Equation (1) via Trun-OLS for each groundnut product separately, and summarize the results in Model (1), (3), and (5) of Table 3. ${ }^{9}$ We also pool all three products together and re-estimate the model, with all trade effects being product-specific; hence the only difference of the pooled model is that it imposes a common error structure across products. These additional results are reported in Model (2), (4), and (6) of Table $3 .^{10}$ The table shows that the pooled model produces similar results as the separate ones. We also conduct several Wald's

\footnotetext{
${ }^{9}$ To ensure that the results are not driven by some influential data points, we also conduct robust regressions in which the observations with higher leverages are down-weighted. The results are very similar to the Truncated OLS models (see Appendix 1 for a full presentation of the results).

${ }^{10}$ Interested readers are referred to the Appendix for a full presentation of the pooled model.
} 
tests on the pooled model to see if it is appropriate to restrict the trade effects of some variables

to be common across three products. The test results in Table 4 indicate a sizeable degree of

heterogeneity among the three products: only the MRL variable and the time fixed effects can be assumed to be common and yet with some provisions. ${ }^{11}$ Therefore, we estimate and interpret each groundnut product separately hereafter.

Table 3: Truncated OLS models

\begin{tabular}{|c|c|c|c|c|c|c|}
\hline & \multicolumn{2}{|c|}{ Edible groundnut } & \multicolumn{2}{|c|}{ Shelled groundnut } & \multicolumn{2}{|c|}{ Groundnut oil } \\
\hline Model & (1) Sectoral & (2) Pooled ${ }^{\mathrm{a}}$ & (3) Sectoral & (4) Pooled ${ }^{\mathrm{a}}$ & (5) Sectoral & (6) Pooled $^{\mathrm{a}}$ \\
\hline$M R L$ & $\begin{array}{l}-0.556 \\
(0.126)\end{array}$ & $\begin{array}{l}-0.556^{*} \\
(0.087)\end{array}$ & $\begin{array}{l}-0.011 \\
(0.974)\end{array}$ & $\begin{array}{l}-0.011 \\
(0.979)\end{array}$ & $\begin{array}{l}1.139 \\
(0.200)\end{array}$ & $\begin{array}{l}1.139 \\
(0.179)\end{array}$ \\
\hline$G D P$ & $\begin{array}{l}-6.667 * * * \\
(0.001)\end{array}$ & $\begin{array}{l}-6.667 * * * \\
(0.001)\end{array}$ & $\begin{array}{l}-0.196 \\
(0.919)\end{array}$ & $\begin{array}{l}-0.196 \\
(0.895)\end{array}$ & $\begin{array}{l}-2.973 \\
(0.343)\end{array}$ & $\begin{array}{l}-2.973 \\
(0.331)\end{array}$ \\
\hline Supply & $\begin{array}{l}0.486 * * * \\
(0.000)\end{array}$ & $\begin{array}{l}0.486 * * * \\
(0.000)\end{array}$ & $\begin{array}{l}0.469 * * * \\
(0.000)\end{array}$ & $\begin{array}{l}0.469 * * * \\
(0.000)\end{array}$ & $\begin{array}{l}0.827 * * * \\
(0.000)\end{array}$ & $\begin{array}{l}0.827 * * * \\
(0.000)\end{array}$ \\
\hline Dist & $\begin{array}{l}-0.477 \\
(0.783)\end{array}$ & $\begin{array}{l}-0.477 \\
(0.800)\end{array}$ & $\begin{array}{l}-1.180 \\
(0.368)\end{array}$ & $\begin{array}{l}-1.180 \\
(0.481)\end{array}$ & $\begin{array}{l}-7.556 * * * \\
(0.000)\end{array}$ & $\begin{array}{l}-7.556 * * * \\
(0.000)\end{array}$ \\
\hline Dlang & $\begin{array}{l}1.177 \\
(0.228)\end{array}$ & $\begin{array}{l}1.177^{*} \\
(0.071)\end{array}$ & $\begin{array}{l}-0.882 * * \\
(0.010)\end{array}$ & $\begin{array}{l}-0.882 * * * \\
(0.007)\end{array}$ & $\begin{array}{l}0.527^{*} \\
(0.052)\end{array}$ & $\begin{array}{l}0.527 * * \\
(0.045)\end{array}$ \\
\hline $\mathrm{R}^{2}$ & 0.578 & 0.730 & 0.480 & 0.730 & 0.827 & 0.730 \\
\hline Obs. & 287 & 980 & 462 & 980 & 231 & 980 \\
\hline
\end{tabular}

$\left(\mathrm{P}\right.$-values are in parenthesis, $\left.{ }^{*} \mathrm{p}<0.10,{ }^{* *} \mathrm{p}<0.05,{ }^{* * *} \mathrm{p}<0.01\right)$. Notes: a. The sector of edible groundnut is chosen as the baseline sector in the pooled regression. The estimates reported in column (4) and (6) are computed as the sums of the main effects and the effects interacting with the product dummy variables. The associated F-statistics of Wald's tests are reported in parentheses in column (4) and (6).

Table 4: Wald tests on the pooled Truncated OLS model

\begin{tabular}{|l|l|l|}
\hline $\begin{array}{l}\text { Null hypothesis: } \\
\text {.. are common across three products }\end{array}$ & F-stat & P value \\
\hline MRL effects & 1.94 & 0.144 \\
\hline GDP effects & 3.24 & 0.040 \\
\hline Supply effects & 4.18 & 0.016 \\
\hline Distance effects & 4.90 & 0.008 \\
\hline Common language effects & 7.17 & 0.001 \\
\hline Time fixed effects & 0.76 & 0.839 \\
\hline Importers' fixed effects & 9.69 & 0.000 \\
\hline Exporters' fixed effects & 4.88 & 0.000 \\
\hline
\end{tabular}

Note: a. Since edible groundnut is chosen as the baseline product in the pooled model, the hypothesis of a common

${ }^{11}$ To investigate the implication of a common MRL response, we re-estimate the model with a single MRL variable. The coefficient turns out insignificant. Hence, although statistically permissible, the assumption of a common MRL response leads to less informative results. Similar issues hold for a few of the time fixed effects. See Appendix 1 for more details. 
response is formulated as the linear restrictions that both the main effect interacting with the oil dummy and the main effect interacting with the shelled nut dummy have no explanatory power.

Table 5: Endogeneity tests

\begin{tabular}{|l|l|l|l|l|l|l|l|}
\hline & & \multicolumn{3}{|l|}{ Edible groundnut } & \multicolumn{2}{l|}{ Shelled groundnut } & \multicolumn{2}{l|}{ Groundnut oil } \\
\hline Variable & Instrument & F-stat & P value & F-stat & P value & F-stat & P value \\
\hline MRL & $\begin{array}{l}\text { One period lagged } \\
\text { MRL }\end{array}$ & 0.07 & 0.796 & 0.12 & 0.730 & 0.92 & 0.338 \\
\hline Supply & $\begin{array}{l}\text { FAOSTAT } \\
\text { production series }\end{array}$ & 0.43 & 0.512 & 0.15 & 0.695 & 0.33 & 0.564 \\
\hline
\end{tabular}

Two interesting observations stand out of Table 3. First of all, MRLs on aflatoxin turn out to have no significant restricting effects on African exports of all three groundnut exports, which contradicts the previous finding by Otsuki et al. (2001). ${ }^{12}$ The only significant estimate, for edible groundnut in the pooled regression, suggests that the MRL actually promotes trade. The contrasting result relative to Otsuki et al. appears to hinge on the inclusion of importer dummies in the specification; the importers' fixed effects capturing the "multilateral resistance" terms had to be omitted in Otsuki et al. (2001). We find several importer dummies to be statistically significant (see Appendix 1 for details), suggesting that the trade-impeding effect found in Otsuki et al. (2001) stems from the multi-lateral resistance terms of some of the importing countries rather than the MRL. When those terms are controlled for, the MRL by itself has no significant impact on groundnut exports from Africa. ${ }^{13}$ Table 5 provides a Hausman endogeneity test of the MRL variable, and no political motive of the regulation is found. The absence of negative trade effect of MRLs casts doubt on the established viewpoint that the EU's MRL policy on aflatoxin is trade-impeding for exporters from African countries.

Two alternative rationalizations can help interpret our result. Either, the MRL regulations

\footnotetext{
${ }^{12}$ To detect the possible long-run effect of MRLs, we also add a new variable, MRL interacting with a linear time trend, and re-estimate the model. The estimate of the new variable is insignificant across all three products, suggesting there is no long-run trade effect of MRLs.

${ }^{13}$ To further support this argument, we also assume away the importers' fixed effects and re-estimate the model. The associated results are in line with Otsuki et al. (2001). The results are available from the authors upon request.
} 
are not binding for African groundnut exporters because other domestic factors in production and export capacity constrain the trade potential in Africa. Or, the potential trade loss of African groundnut exporters due to the compliance cost associated with the tighter standard is offset by the trade benefits originated from an enhanced EU demand given consumers' preferences for safer groundnut products. ${ }^{14}$ In addition, African supply is found to positively influence exports across specifications and products, which suggests the key importance of domestic production capacity in Africa to explain its trade potential. A Hausman endogeneity test is also conducted in Table 5 to check if the supply proxy is endogenous to bilateral trade flows. No evidence of endogeneity is found for all three groundnut products.

The computational simplicity of the Trun-OLS is an advantage. However, the Trun-OLS estimator suffers from several criticisms. One major statistical problem is the potential sample selection bias it can cause if the eliminated zero observations are not drawn on a random basis. This is potentially our case since countries choose voluntarily not to trade with each other. Even if a sample selection bias is not detected, the economic interpretations of truncated OLS estimates are limited. In our application, a Trun-OLS estimate for any variable of interest would only capture its intensive margin to trade, that is, the intensification of existing trade (marginal effects conditional on trade already taking place). However, from a development viewpoint it is the extensive margin to trade, the creation of new bilateral trade partnerships, that we are interested in. Have the harmonization and tightening of the EU aflatoxin regulation decreased the international market accessibility for groundnut exporters from Africa? The latter concern naturally motivates a Heckman-type sample selection model, which we pursue next.

We choose the HMR approach which is the state-of-the-art of the gravity equation

\footnotetext{
${ }^{14}$ The evolvement of the prices would help distinguish the two rationalizations. Unfortunately, the retail price series of African groundnut products sold in EU markets are not currently available.
} 
approach to trade with sample selection. The HMR approach generates an extended gravity equation model with firm-level heterogeneity in productivity. The model exhibits three appealing features. First, it explains zero trade flows. The absence of bilateral trade occurs when all producers, even the most efficient ones, within a country find it unprofitable to export to a destination. Second, HMR deals with the sample selection bias defined by Heckman (1979). A selection equation accounts for the qualitative choice of outcomes, whether or not to trade with an EU country in our context. This selection equation and the outcome equations (the equation with positive observations only) are jointly estimated via a maximum likelihood method or a two-step procedure.

Third, HMR controls for the trade effect of the fraction of exporting firms, which varies across exporting countries due to the different degrees of firm-level heterogeneity. Only the most productive firms export because exports entail some additional fixed costs relative to selling domestically. Econometrically, this additional term in the outcome equation can be consistently estimated from the first stage of the Heckman two-stage procedure. To help with the identification, at least one explanatory variable included in the selection equation is excluded from the outcome equation. Economic theory suggests that a variable that affects the fixed costs of EU-African trade, but not the variable costs of trade, would qualify. We let the colony dummy variable serve this role. ${ }^{15}$ The HMR in our application is specified as follows:

\footnotetext{
${ }^{15}$ The colony dummy is empirically preferable to the common language dummy as the excluded variable because it stands out significant in the selection equation in two out of the three products, while the common language has null explanatory power on any selection equations (see Table 6 below). The common language variable also leads to convergence problems in HMR when used as the excluded variable.
} 


$$
\begin{aligned}
& \operatorname{Pr}\left(Y_{i j t}^{k}>\right.0)=\Phi\left(\tilde{\beta}_{0}^{k}+\tilde{\beta}_{1}^{k} \ln \left(M R L_{j t}^{k}\right)+\tilde{\beta}_{2}^{k} \ln \left(G D P_{j t}\right)+\tilde{\beta}_{3}^{k} \ln \left(\text { Supply }_{i t}^{k}\right)+\tilde{\beta}_{4}^{k} \ln \left(\text { Dist }_{i j}\right)+\tilde{\beta}_{5}^{k} \text { Dlang }_{i j}\right. \\
&\left.+\tilde{\beta}_{6}^{k} \text { Dcol }_{i j}+\sum_{t=1}^{18} \tilde{\alpha}_{t}^{k} \text { Year }_{t}+\sum_{m=1}^{8} \tilde{\gamma}_{m}^{k} \operatorname{Dex}_{m}+\sum_{n=1}^{13} \tilde{\eta}_{n}^{k} \operatorname{Dim}_{n}\right), \\
& \ln \left(Y_{i j t}^{k} \mid Y_{i j t}^{k}>0\right)=\beta_{0}^{k}+\beta_{1}^{k} \ln \left(M R L_{j t}^{k}\right)+\beta_{2}^{k} \ln \left(G D P_{j t}\right)+\beta_{3}^{k} \ln \left(\text { Supply }_{i t}^{k}\right)+\beta_{4}^{k} \ln \left(\text { Dist }_{i j}\right) \\
&+\beta_{5}^{k} \operatorname{Dlang}_{i j}+\sum_{t=1}^{18} \alpha_{t}^{k} Y_{e a r}+\sum_{m=1}^{8} \gamma_{m}^{k} \operatorname{Dex}_{m}+\sum_{n=1}^{13} \eta_{n}^{k} \operatorname{Dim}_{n} \\
&+\ln \left\{\exp \left[\delta^{k}\left(\hat{z}_{i j t}^{k}+I M R_{i j t}^{k}\right)\right]-1\right\}+\eta^{k} I M R_{i j t}^{k}+u_{i j t} .
\end{aligned}
$$

Selection equation (2) is essentially a standard Probit binary choice model, where $\Phi(\bullet)$ is the standard normal distribution function, $D c o l_{i j}$ is the colonial tie dummy variable for the country pair $i$ and $j$. We assume that this colony variable affects the fixed cost of trade, but has negligible effects on the variable costs to trade. Therefore, it is excluded from outcome equation (3) to help with the identification of the model.

In (3), the term $\ln \left\{\exp \left[\delta^{k}\left(\hat{z}_{i j t}^{k}+I M R_{i j t}^{k}\right)\right]-1\right\}$ captures the trade effect of the fraction of firms in country $i$ that export to country $j$ in year $t .{ }^{16}$ Specifically, $\delta^{k}>0$ is a parameter to be estimated: a larger $\delta^{k}$ corresponds to a greater degree of heterogeneity in productivity across firms in sector $k$, with more unproductive firms and fewer productive ones. $\hat{z}_{i j t}^{k}$ is the linear prediction calculated from estimates of (2). The inverse Mill's ratio, $I M R_{i j t}^{k}$, computed from the estimates in (2) as well, controls for the standard sample selection errors as in Heckman (1979). We follow HMR to consistently estimate the model through a two-step procedure. ${ }^{17}$ In the first step, (2) is estimated via Maximum Likelihood method, and the predicted probability to trade $\hat{z}_{i j t}^{k}$ and Inverse Mill's Ratios $I M R_{i j t}^{k}$ can be computed accordingly. In the second step, (3) is estimated via Non-Linear Least Squares.

\footnotetext{
${ }^{16}$ Readers are referred to Equation (14) in HMR for its derivation.

17 Though desirable to estimate the model via a joint Maximum Likelihood method for efficiency consideration, the non-linearity of the outcome equation makes the log-likelihood function intractable.
} 
The results of the HMR model are reported in Table $6 .{ }^{18}$ We discuss the estimates in the selection equations and the outcome equations, in turn. Two interesting findings come from the estimated selection equation. First, the decision of trade or not is indeed an endogenous outcome as we expect. The estimates in the selection equations show that a larger European GDP, a more abundant supply, or a historical colonial tie will help create new trade partnership between the African groundnut exporters and the European importers. Second, the MRL policy on aflatoxin has very little impact on the extensive margin to trade. In other words, the MRL policy on aflatoxin imposed by the EU does not appear to decrease market access for African exporters.

The estimates in the outcome equations convey three important messages. First, the MRL imposed by the EU has negligible effects on the existing trade volumes between Africa and the EU. The P-values associated with the MRL estimates suggest that the policy is not statistically significant at $10 \%$ level for any groundnut product under consideration. Second, among all other bilateral trade determinants, African domestic supply is the only systematic contributor to exporting all three products.

Edible groundnuts appear to be an inferior good (significantly negative estimate for GDP), whereas income does not seem to influence the trade level of the other two products. The importer fixed effects may also account for some of the income variation across EU countries. A longer distance impedes the trade volumes for all three products but its effects on the probability of trade in edible groundnuts and shelled groundnuts are unexpected. Further discussion of the distance effect follows the model selection part in Section 5. A colonial tie in history promotes the creation of new trade and is statistically significant for two out of the three products, which in part confirms its qualification as the excluded variable. The role of the common language is

\footnotetext{
${ }^{18}$ We also estimate the model via standard Heckman Maximum Likelihood method without controlling for the firmlevel heterogeneity. The estimates are qualitatively similar to those in Table 6.
} 
insignificant in all three selection equations and with a strong significantly negative effect on the trade volumes in shelled groundnuts, which is unexpected. This result is further discussed in the model selection part in Section 5 .

Thirdly, the potential sample selection problem and the omission of the fraction of exporting firms seem not to severely bias the conventional trun-OLS estimates. In fact, the existing firms' margins in the outcome equations of the HMR are comparable to Models (1), (3), and (5) of Table 3. The sample selection term, represented by the Inverse Mill's Ratio, turns out not statistically significant for all three groundnut products. The findings on the new firms' margins exhibit three intriguing features. First of all, some trade cost terms do affect trade flows through altering the behavior of new entrants, as evidenced by several significant new firms’ margins in Table 6. This result underscores the importance of controlling for the new firms' margins. Secondly, a trade cost term can have very different impact on the incumbents versus new entrants. For example, the African domestic supplies positively affect trade flows in all three products both by boosting the incumbents' sale and by increasing in the number of exporting firms. In contrast, the EU income response for edible groundnuts and groundnut oil from Africa suggests they are probably inferior products (negative income response in the existing firms' margin), although new trade of these products, both at the country-level (extensive margins) and at the firm-level (new firms’ margin), is more likely to occur with large EU countries. Lastly, the existing firms' margin doesn't always dominate the new firms' margin. Although the existing firms' margin is larger in magnitude for most of variables in Table 6, the distance effects in the sector of edible groundnut indicates that sometimes newly entered firms are more sensitive to certain market conditions than incumbents. 
Table 6: Helpman-Melitz-Rubinstein models

\begin{tabular}{|c|c|c|c|c|c|c|c|c|c|}
\hline & \multicolumn{3}{|c|}{ Edible groundnut } & \multicolumn{3}{|c|}{ Shelled groundnut } & \multicolumn{3}{|c|}{ Groundnut oil } \\
\hline & $\begin{array}{l}\text { Extensive } \\
\text { Margin }^{\mathrm{a}}\end{array}$ & $\begin{array}{l}\text { Existing } \\
\text { Firms' } \\
\text { Margin }^{\mathrm{b}}\end{array}$ & $\begin{array}{l}\text { New } \\
\text { Firms' } \\
\text { Margin }^{c}\end{array}$ & $\begin{array}{l}\text { Extensive } \\
\text { Margin }^{\mathrm{a}}\end{array}$ & $\begin{array}{l}\text { Existing } \\
\text { Firms' } \\
\text { Margin }^{b}\end{array}$ & $\begin{array}{l}\text { New } \\
\text { Firms' } \\
\text { Margin }^{c}\end{array}$ & $\begin{array}{l}\text { Extensive } \\
\text { Margin }^{\mathrm{a}}\end{array}$ & $\begin{array}{l}\text { Existing } \\
\text { Firms' } \\
\text { Margin }^{b}\end{array}$ & $\begin{array}{l}\text { New } \\
\text { Firms' } \\
\text { Margin }^{c}\end{array}$ \\
\hline$M R L$ & $\begin{array}{l}-0.165 \\
(0.280)\end{array}$ & $\begin{array}{l}-0.408 \\
(0.271)\end{array}$ & $\begin{array}{l}-0.096 \\
(0.280)\end{array}$ & $\begin{array}{l}-0.030 \\
(0.807)\end{array}$ & $\begin{array}{l}0.031 \\
(0.926)\end{array}$ & $\begin{array}{l}-0.011 \\
(0.807)\end{array}$ & $\begin{array}{l}0.759 \\
(0.234)\end{array}$ & $\begin{array}{l}1.006 \\
(0.497)\end{array}$ & $\begin{array}{l}0.221 \\
(0.234)\end{array}$ \\
\hline$G D P$ & $\begin{array}{l}1.156^{* * *} \\
(0.001)\end{array}$ & $\begin{array}{l}-7.150 * * * \\
(0.001)\end{array}$ & $\begin{array}{l}0.671 * * * \\
(0.001)\end{array}$ & $\begin{array}{l}0.820 \\
(0.177)\end{array}$ & $\begin{array}{l}0.089 \\
(0.963)\end{array}$ & $\begin{array}{l}0.289 \\
(0.177)\end{array}$ & $\begin{array}{l}1.602 * * * \\
(0.000)\end{array}$ & $\begin{array}{l}-4.007 \\
(0.311)\end{array}$ & $\begin{array}{l}0.466^{* * *} \\
(0.000)\end{array}$ \\
\hline Supply & $\begin{array}{l}0.073 * * \\
(0.035)\end{array}$ & $\begin{array}{l}0.441 * * * \\
(0.001)\end{array}$ & $\begin{array}{l}0.043 * * \\
(0.035)\end{array}$ & $\begin{array}{l}0.363^{* * *} \\
(0.000)\end{array}$ & $\begin{array}{l}0.276 \\
(0.123)\end{array}$ & $\begin{array}{l}0.128 * * * \\
(0.000)\end{array}$ & $\begin{array}{l}0.272 * * * \\
(0.000)\end{array}$ & $\begin{array}{l}0.836 * \\
(0.076)\end{array}$ & $\begin{array}{l}0.079 * * * \\
(0.000)\end{array}$ \\
\hline Dist & $\begin{array}{l}1.268 * * * \\
(0.002)\end{array}$ & $\begin{array}{l}-0.395 \\
(0.841)\end{array}$ & $\begin{array}{l}0.736 * * * \\
(0.002)\end{array}$ & $\begin{array}{l}0.699 * * \\
(0.012)\end{array}$ & $\begin{array}{l}-1.403 \\
(0.291)\end{array}$ & $\begin{array}{l}0.246^{* *} \\
(0.012)\end{array}$ & $\begin{array}{l}-1.634 * * * \\
(0.009)\end{array}$ & $\begin{array}{l}-7.372 * * \\
(0.046)\end{array}$ & $\begin{array}{l}-0.475^{\text {*** }} \\
(0.009)\end{array}$ \\
\hline Dlang & $\begin{array}{l}-0.264 \\
(0.345)\end{array}$ & $\begin{array}{l}1.082 \\
(0.279)\end{array}$ & $\begin{array}{l}-0.153 \\
(0.345)\end{array}$ & $\begin{array}{l}0.122 \\
(0.520)\end{array}$ & $\begin{array}{l}-1.399 * * * \\
(0.002)\end{array}$ & $\begin{array}{l}0.043 \\
(0.520)\end{array}$ & $\begin{array}{l}-0.046 \\
(0.855)\end{array}$ & $\begin{array}{l}0.360 \\
(0.301)\end{array}$ & $\begin{array}{l}-0.013 \\
(0.855)\end{array}$ \\
\hline Dcol $^{d}$ & $\begin{array}{l}0.913 * * * \\
(0.005)\end{array}$ & N.A. & $\begin{array}{l}0.530 * * * \\
(0.005)\end{array}$ & $\begin{array}{l}1.202^{* * *} \\
(0.000)\end{array}$ & N.A. & $\begin{array}{l}0.423 * * * \\
(0.000)\end{array}$ & $\begin{array}{l}0.288 \\
(0.321)\end{array}$ & N.A. & $\begin{array}{l}0.084 \\
(0.321)\end{array}$ \\
\hline$I M R^{e}$ & N.A. & $\begin{array}{l}0.764 \\
(0.456)\end{array}$ & N.A. & N.A. & $\begin{array}{l}0.136 \\
(0.821)\end{array}$ & N.A. & N.A. & $\begin{array}{l}0.590 \\
(0.757)\end{array}$ & N.A. \\
\hline Obs. & 1736 & & & 2156 & & & 1470 & & \\
\hline
\end{tabular}

(P-values are in parenthesis, $\left.{ }^{*} \mathrm{p}<0.05,{ }^{* *} \mathrm{p}<0.01,{ }^{* * *} \mathrm{p}<0.001\right)$. Notes: a. The extensive margin is defined as the derivative of the logarithmicscaled probability of trade with respect to the exogenous variable of interest. See Appendix 2 for details. b. The existing firms' margin corresponds to the estimate in the second step of HMR, $\beta^{k}$. See Appendix 2 for details. c. The new firms' margin is defined as the derivative of the non-linear term in the second step of HMR with respect to the exogenous variable of interest. See Appendix 2 for details. d. The colony dummy is excluded from the outcome equations for the identification purpose. e. The Inverse Mill's ratio, computed from the estimates of the first-stage selection equations, corrects for the sample selection bias in the outcome equations.

Although firmly grounded in economic theory, the HMR model suffers from two major critiques. The logarithmic transformation of the trade flows in the outcome equation could lead to biased estimates of the elasticities. As Silva and Tenreyro (2006) note, the logarithmic transformation often leads to correlation between the error terms and exogenous variables, thus to biased elasticity estimates in the outcome equations. The Ramsey specification test (Ramsey, 1969) can be used to detect whether the outcome equations are correctly specified. The other concern, raised by Silva and Tenreyro (2008), is that non-linear term capturing the trade effects of new firms is mis-specified if the selection equation exhibits heteroksedasticity. Therefore, a heteroskedasticity test on the first-stage Probit models should be used for diagnostic purpose. We report the two tests in Table 7. The test results show that the elasticity estimates in the outcome equation for groundnut oil could be biased severely due to the logarithmic transformation. The 
decision to trade exhibits a great degree of heteroskedasticity in all three products, implying that the non-linear term in the second-stage of the HMR model is mis-specified.

Table 7: Tests on the HMR models

\begin{tabular}{|l|l|l|l|l|l|l|}
\hline & \multicolumn{2}{|l|}{ Edible groundnut } & \multicolumn{2}{l|}{ Shelled groundnut } & \multicolumn{2}{l|}{ Groundnut oil } \\
\hline $\begin{array}{l}\text { Ramsey test on outcome } \\
\text { equations }\end{array}$ & F-stat & P value & F-stat & P value & F-stat & P value \\
\hline$H_{0}:$ no specification error. $^{\text {a }}$ & 0.02 & 0.899 & 1.48 & 0.224 & 3.91 & 0.049 \\
\hline $\begin{array}{l}\text { Heteroskedasticity test on } \\
\text { selection equations }\end{array}$ & $\chi^{2}$-stat & P value & $\chi^{2}$-stat & P value & $\chi^{2}$-stat & P value \\
\hline$H_{0}$ : homoskedasticity. $^{\text {b }}$ & 33.63 & 0.000 & 11.50 & 0.001 & 19.81 & 0.000 \\
\hline
\end{tabular}

Note: a. Following Silva and Tenreyro (2006), the squared fitted value is used as the additional regressor in the auxiliary regression. The significance of this additional regressor suggests the mis-specification of the conditional mean in the original model. $\mathrm{b}$. The alternative hypothesis is that the variance of the selection equations is proportional to the variable African supply. If African supply significantly explains the variance, $H_{0}$ is rejected.

Another concern with the gravity equation approach is the inherent heteroskedasticity in the trade data combined to the log-linearization of the original multiplicative form of the gravity equation. Jensen's inequality implies that the estimates of the log-linearized model in general do not correspond to the true elasticities we are interested in. To address this concern, we follow Silva and Tenreyro (2006) and Burger, Van Oort, and Linders (2009) to re-estimate the gravity equation in levels via the Poisson family of pseudo maximum likelihood estimators. The PPML estimator proposed by Silva and Tenreyro (2006) has been shown to be robust to various heteroskedastic patterns as long as the conditional variance of the dependent variable is proportional to its conditional mean. However, this condition can be violated when the data exhibits excessive zero outcomes. The excessive zeros can either result from the over-dispersion of the data generating process, or the existence of another data generating process that produces inflated zeros (Greene (1994)). In order to accommodate those excessive zeros and identify their underlying processes, variants of PPML such as NBPML, ZIPPML, and ZINBPML are used and statistical tests lead to selecting a preferred variant. Note that all 4 pseudo maximum likelihood estimators numerically allow for zero observations. 
The specification of the PPML model is as follows:

$$
\begin{aligned}
E\left(Y_{i j}^{k} \mid X_{i j t}^{k}\right) & =\exp \left[\beta_{0}^{k}+\beta_{1}^{k} \ln \left(M R L_{j t}^{k}\right)+\beta_{2}^{k} \ln \left(G D P_{j t}\right)+\beta_{3}^{k} \ln \left(\operatorname{Supply}_{i t}^{k}\right)+\beta_{4}^{k} \ln \left(\text { Dist }_{i j}\right)\right. \\
& \left.+\beta_{5}^{k} \text { Dlang }_{i j}+\beta_{6}^{k} \text { Dcol }_{i j}+\sum_{t=1}^{18} \alpha_{t}^{k} \text { Year }_{t}+\sum_{m=1}^{8} \gamma_{m}^{k} \operatorname{Dex}_{m}+\sum_{n=1}^{13} \eta_{n}^{k} \operatorname{Dim}_{n}\right]
\end{aligned}
$$

where $X_{i j t}^{k}$ is the matrix containing all explanatory variables under consideration. The consistency of the PPML estimator is insured assuming $\operatorname{Var}\left(Y_{i j t}^{k} \mid X_{i j t}^{k}\right) \infty E\left(Y_{i j t}^{k} \mid X_{i j t}^{k}\right)$. The conditional mean of the NBPML model is also based on (4), but allowing for over-dispersion, $\operatorname{Var}\left(Y_{i j t}^{k} \mid X_{i j t}^{k}\right) \infty E^{2}\left(Y_{i j t}^{k} \mid X_{i j t}^{k}\right)$

The zero-inflated variants, ZIPPML and ZINBPML, are specified in the following way:

$$
\operatorname{Pr}\left(Y_{i j t}^{k}=y \mid x_{i j t}^{k}\right)= \begin{cases}\Phi\left(x_{i j t}^{k} \gamma^{k}\right)+\left(1-\Phi\left(x_{i j t}^{k} \gamma^{k}\right)\right) f\left(0 \mid x_{i j t}^{k}\right) & \text { if } y=0 \\ \left(1-\Phi\left(x_{i j t}^{k} \gamma^{k}\right)\right) f\left(y \mid x_{i j t}^{k}\right) & \text { if } y>0\end{cases}
$$

where $\Phi\left(x_{i j t}^{k} \gamma^{k}\right)$ is the probability of zero trade flows due to exporters' self-selection to be absent from the export market, $f(\bullet)$ is the density function of the data generating process that produces the levels of trade flows conditioning on the self-selection to trade. With the ZIPPML method, the data generating process has a mean of $\exp \left(x_{i j t}^{k} \beta^{k}\right)$, and $\operatorname{Var}\left(Y_{i j t}^{k} \mid X_{i j t}^{k}\right) \infty E\left(Y_{i j t}^{k} \mid X_{i j t}^{k}\right)$. In ZINBPML, the data generating process has the same mean, but $\operatorname{Var}\left(Y_{i j t}^{k} \mid X_{i j t}^{k}\right) \infty E^{2}\left(Y_{i j t}^{k} \mid X_{i j t}^{k}\right)$. Notably, there are two sources of zero trade flows in the zero-inflated models. Either, an exporter decides not to trade in the first stage, or it decides to trade but is hit by a negative cost shock which makes the trade volumes zero. As in the HMR model and for consistency across selection and inflation equations, we assume that the colonial tie between countries tends to affect the decision to trade, but not the conditional trade volumes. To sum up, 4 pseudo maximum likelihood estimators are used with associated tests to select the proper Poisson specification. First, the difference between PPML and ZIPPML (as well as for NBPML and ZINBPML) hinges 
on the existence of another data generating process that produces excessive zeros caused by selfselection into no trade. A Vuong test (Vuong (1989)) is used to distinguish the zero-inflated model and its regular counterpart. Second, ZIPPML is a special case of ZINBPML when overdispersion is not established in the data generating process of the trade levels. Statistically, the existence of over-dispersion is tested using a standard likelihood-ratio test (with the null hypothesis that the dispersion parameter is zero). NBPML nests PPML as a special case in a similar way.

We report the PPML, NBPML, ZIPPML, and ZINBPML results for edible groundnuts, shelled groundnuts, and groundnut oil in Tables 8 through 10, along with the Vuong tests and dispersion tests. ${ }^{19}$ The likelihood ratio tests of the possible over-dispersion suggest that the trade flows in all three products are significantly over-dispersed, whether or not a different selection process is in place to account for the reluctance to trade. Therefore, PPML and ZIPPML are dominated by NBPML and ZINBPML respectively. The additional Vuong tests show that PPML and NBPML are inferior to their zero-inflated variants ZIPPML and ZINBPML, implying that a binary choice process is indeed necessary to account for firms' self-selection to not trade. Based on the statistical tests above, ZINBPML is the most preferable model out of the four pseudo maximum likelihood estimators in our particular application. Hence, we focus on ZINBPML in the result discussion and interpretation.

Table 8: Pseudo maximum likelihood models for edible groundnuts

\begin{tabular}{|l|l|l|l|l|l|l|}
\hline Model & PPML & NBPML & $\begin{array}{l}\text { ZIPPML } \\
\text { Ext. Marg. }\end{array}$ & $\begin{array}{l}\text { ZIPPML } \\
\text { Int. Marg }^{b}\end{array}$ & $\begin{array}{l}\text { ZINBPML } \\
\text { Ext. Marg }^{\text {a }}\end{array}$ & $\begin{array}{l}\text { ZINBPML } \\
\text { Int. Marg }^{\text {b }}\end{array}$ \\
\hline MRL & $-0.435^{*}$ & $-0.716^{* *}$ & -0.363 & -0.354 & -0.305 & $-0.697^{*}$ \\
& $(0.056)$ & $(0.022)$ & $(0.149)$ & $(0.100)$ & $(0.291)$ & $(0.075)$ \\
\hline$G D P$ & $2.637^{*}$ & $2.286^{* * *}$ & -1.017 & $3.058^{*}$ & $3.053^{* * *}$ & $-5.743^{* * *}$ \\
& $(0.070)$ & $(0.000)$ & $(0.736)$ & $(0.071)$ & $(0.000)$ & $(0.000)$ \\
\hline
\end{tabular}

\footnotetext{
${ }^{19}$ The Vuong test is essentially a likelihood ratio test. The associated statistic is normally distributed, with a large positive value in favor of the ZIPPML (ZINBPML) model and a large negative value in favor of the PPML (NBPML) model. See Vuong (1989, p. 318) for more details.
} 


\begin{tabular}{|c|c|c|c|c|c|c|}
\hline Supply & $\begin{array}{l}0.407 * * * \\
(0.000)\end{array}$ & $\begin{array}{l}0.252 * * * \\
(0.000)\end{array}$ & $\begin{array}{l}0.040 \\
(0.473)\end{array}$ & $\begin{array}{l}0.395 * * * \\
(0.000)\end{array}$ & $\begin{array}{l}-0.139 * \\
(0.074)\end{array}$ & $\begin{array}{l}0.447 * * \\
(0.035)\end{array}$ \\
\hline Dist & $\begin{array}{l}2.356^{*} \\
(0.056)\end{array}$ & $\begin{array}{l}3.439 * * * \\
(0.001)\end{array}$ & $\begin{array}{l}2.247 * * * \\
(0.000)\end{array}$ & $\begin{array}{l}-1.111 \\
(0.419)\end{array}$ & $\begin{array}{l}-2.046 * \\
(0.060)\end{array}$ & $\begin{array}{l}4.684 * * * \\
(0.004)\end{array}$ \\
\hline Dcol & $\begin{array}{l}1.274^{* * *} \\
(0.007)\end{array}$ & $\begin{array}{l}1.986^{* * *} \\
(0.000)\end{array}$ & $\begin{array}{l}1.434^{* * *} \\
(0.000)\end{array}$ & N.A. & $\begin{array}{l}0.801 \\
(0.211)\end{array}$ & N.A. \\
\hline dlang & $\begin{array}{l}-1.134 \\
(0.121)\end{array}$ & $\begin{array}{l}-0.472 \\
(0.362)\end{array}$ & $\begin{array}{l}-0.559 \\
(0.234)\end{array}$ & $\begin{array}{l}0.122 \\
(0.798)\end{array}$ & $\begin{array}{l}-0.235 \\
(0.705)\end{array}$ & $\begin{array}{l}0.472 \\
(0.636)\end{array}$ \\
\hline Dispersion & N.A. & $\begin{array}{l}9.2 * * * \\
(0.000)\end{array}$ & N.A. & N.A. & $\begin{array}{l}3.212^{* * *} \\
(0.000)\end{array}$ & \\
\hline \multicolumn{3}{|c|}{$\begin{array}{l}\text { Vuong statistic } \\
\text { (P value) }\end{array}$} & \multicolumn{2}{|l|}{$\begin{array}{l}6.73 * * * \\
(0.000)\end{array}$} & $\begin{array}{l}7.15 * * * \\
(0.000)\end{array}$ & \\
\hline
\end{tabular}

$\left(\mathrm{P}\right.$-values are in parenthesis, $\left.{ }^{*} \mathrm{p}<0.1,{ }^{* *} \mathrm{p}<0.05,{ }^{* * *} \mathrm{p}<0.01\right)$. Notes: a. The extensive margin in ZIPPML/ZINBPML is defined as the derivative of the logarithm-scaled probability of trade with respect to the variable of interest. See Appendix 2 for details. b. The intensive margin in ZIPPML/ZINBPML is defined as the elasticity of trade flows with respect to the variable of interest, corresponding to raw coefficients in the outcome equations. See Appendix 2 for details. c.Vuong statistic is a likelihood ratio of two unnested models, with a large positive value in favor of the zero-inflated model and a large negative value in favor of the other.

Table 9: Pseudo maximum likelihood models for shelled groundnuts

\begin{tabular}{|c|c|c|c|c|c|c|}
\hline Model & PPML & NBPML & $\begin{array}{l}\text { ZIPPML } \\
\text { Ext. Marg. }\end{array}$ & $\begin{array}{l}\text { ZIPPML } \\
\text { Int. Marg }\end{array}$ & $\begin{array}{l}\text { ZINBPML } \\
\text { Ext. Marga }\end{array}$ & $\begin{array}{l}\text { ZINBPML } \\
\text { Int. Marg }\end{array}$ \\
\hline$M R L$ & $\begin{array}{l}-0.340 \\
(0.197)\end{array}$ & $\begin{array}{l}1.330 * * * \\
(0.000)\end{array}$ & $\begin{array}{l}-0.015 \\
(0.955)\end{array}$ & $\begin{array}{l}-0.509 * \\
(0.046)\end{array}$ & $\begin{array}{l}-0.129 \\
(0.687)\end{array}$ & $\begin{array}{l}0.248 \\
(0.346)\end{array}$ \\
\hline$G D P$ & $\begin{array}{l}7.463 * * * \\
(0.004)\end{array}$ & $\begin{array}{l}2.685^{*} \\
(0.099) \\
\end{array}$ & $\begin{array}{l}-0.002 \\
(0.999) \\
\end{array}$ & $\begin{array}{l}6.424^{* * * *} \\
(0.001)\end{array}$ & $\begin{array}{l}2.451 \\
(0.115) \\
\end{array}$ & $\begin{array}{l}1.088 \\
(0.355) \\
\end{array}$ \\
\hline Supply & $\begin{array}{l}1.134 * * * \\
(0.000)\end{array}$ & $\begin{array}{l}1.338 * * * \\
(0.000)\end{array}$ & $\begin{array}{l}0.709 * * * \\
(0.000)\end{array}$ & $\begin{array}{l}0.713^{* * *} \\
(0.000)\end{array}$ & $\begin{array}{l}0.713^{* * *} \\
(0.000)\end{array}$ & $\begin{array}{l}0.653^{* * * *} \\
(0.000)\end{array}$ \\
\hline Dist & $\begin{array}{l}-2.497 * * * \\
(0.000)\end{array}$ & $\begin{array}{l}3.104^{* * * *} \\
(0.000)\end{array}$ & $\begin{array}{l}1.665^{* * * *} \\
(0.006)\end{array}$ & $\begin{array}{l}-8.102^{* *} \\
(0.010)\end{array}$ & $\begin{array}{l}2.087 * * * \\
(0.003)\end{array}$ & $\begin{array}{l}-1.452 \\
(0.566) \\
\end{array}$ \\
\hline Dcol & $\begin{array}{l}1.229 * * * \\
(0.000)\end{array}$ & $\begin{array}{l}1.776^{* * * *} \\
(0.001)\end{array}$ & $\begin{array}{l}2.293 * * * \\
(0.000)\end{array}$ & N.A. & $\begin{array}{l}2.603^{* * *} \\
(0.000)\end{array}$ & N.A. \\
\hline dlang & $\begin{array}{l}-0.521 \\
(0.144) \\
\end{array}$ & $\begin{array}{l}0.054 \\
(0.908) \\
\end{array}$ & $\begin{array}{l}0.398 \\
(0.243) \\
\end{array}$ & $\begin{array}{l}-0.491^{* *} \\
(0.050)\end{array}$ & $\begin{array}{l}0.943 * * \\
(0.021) \\
\end{array}$ & $\begin{array}{l}-1.121^{* * *} \\
(0.000)\end{array}$ \\
\hline Dispersion & N.A. & $\begin{array}{l}16.385^{* * * *} \\
(0.000)\end{array}$ & N.A. & N.A. & \multicolumn{2}{|l|}{$\begin{array}{l}3.264 * * * \\
(0.000)\end{array}$} \\
\hline \multicolumn{3}{|c|}{$\begin{array}{l}\text { Vuong statistic }{ }^{\mathrm{C}} \\
\text { (P value) }\end{array}$} & \multicolumn{2}{|l|}{$\begin{array}{l}15.66^{* * *} \\
(0.000)\end{array}$} & \multicolumn{2}{|l|}{$\begin{array}{l}7.92 * * * \\
(0.000)\end{array}$} \\
\hline
\end{tabular}

(P-values are in parenthesis, ${ }^{*} \mathrm{p}<0.1,{ }^{* *} \mathrm{p}<0.05$, ${ }^{* * *} \mathrm{p}<0.01$ ). Notes: a. The extensive margin in ZIPPML/ZINBPML is defined as the derivative of the logarithm-scaled probability of trade with respect to the variable of interest. See Appendix 2 for details. b. The intensive margin in ZIPPML/ZINBPML is defined as the elasticity of trade flows with respect to the variable of interest, corresponding to raw coefficients in the outcome equations. See Appendix 2 for details. c.Vuong statistic is a likelihood ratio of two non-nested models, with a large positive value in favor of the zero-inflated model, and a large negative value in favor of the other.

Table 10: Pseudo maximum likelihood models for groundnut oil

\begin{tabular}{|l|l|l|l|l|l|l|}
\hline Model & PPML & NBPML & $\begin{array}{c}\text { ZIPPML } \\
\text { Ext. Marg. }^{\text {a }}\end{array}$ & $\begin{array}{l}\text { ZIPPML } \\
\text { Int. Marg }^{b}\end{array}$ & $\begin{array}{l}\text { ZINBPML } \\
\text { Ext. Marg }^{\text {a }}\end{array}$ & $\begin{array}{l}\text { ZINBPML } \\
\text { Int. Marg }^{\text {b }}\end{array}$ \\
\hline
\end{tabular}




\begin{tabular}{|l|l|l|l|l|l|l|}
\hline MRL & $2.997^{* * *}$ & 1.560 & 1.826 & $2.077^{* *}$ & 1.831 & 1.034 \\
& $(0.001)$ & $(0.215)$ & $(0.150)$ & $(0.018)$ & $(0.151)$ & $(0.208)$ \\
\hline GDP & $2.262^{* * *}$ & $6.016^{* * *}$ & $3.854^{* * *}$ & -2.550 & $3.851^{* * *}$ & -1.335 \\
& $(0.000)$ & $(0.000)$ & $(0.000)$ & $(0.165)$ & $(0.000)$ & $(0.515)$ \\
\hline Supply & $1.082^{* * *}$ & $1.437^{* * *}$ & $0.638^{* * *}$ & $0.847^{* * *}$ & $0.641^{* * *}$ & $0.737^{* * *}$ \\
& $(0.000)$ & $(0.000)$ & $(0.000)$ & $(0.000)$ & $(0.000)$ & $(0.000)$ \\
\hline Dist & $-8.132^{* * *}$ & $-3.949^{* * *}$ & $-3.756^{* * *}$ & $-7.018^{* * *}$ & $-3.770^{* * *}$ & $-6.768^{* * *}$ \\
& $(0.000)$ & $(0.001)$ & $(0.002)$ & $(0.000)$ & $(0.002)$ & $(0.000)$ \\
\hline Dcol & -0.067 & $1.433^{* *}$ & 0.671 & N.A. & 0.668 & N.A. \\
& $(0.872)$ & $(0.032)$ & $(0.288)$ & & $(0.290)$ & \\
\hline dlang & 0.048 & -0.986 & -0.093 & 0.359 & -0.095 & $0.422^{* *}$ \\
& $(0.913)$ & $(0.105)$ & $(0.871)$ & $(0.204)$ & $(0.868)$ & $(0.016)$ \\
\hline Dispersion & N.A. & $15.103^{* * *}$ & N.A. & N.A. & $0.692^{* * *}$ & \\
& & $(0.000)$ & & & $(0.000)$ & \\
\hline Vuong statistic & & & $11.76^{* * *}$ & & $7.09^{* * *}$ & \\
(P value) & & $(0.000)$ & & $(0.000)$ & \\
\hline
\end{tabular}

(P-values are in parenthesis, $\left.{ }^{*} \mathrm{p}<0.1,{ }^{* *} \mathrm{p}<0.05,{ }^{* * *} \mathrm{p}<0.01\right)$. Notes: a. The extensive margin in ZIPPML/ZINBPML is defined as the derivative of the logarithm-scaled probability of trade with respect to the variable of interest. See Appendix 2 for details. b. The intensive margin in ZIPPML/ZINBPML is defined as the elasticity of trade flows with respect to the variable of interest, corresponding to raw coefficients in the outcome equations. See Appendix 2 for details. c.Vuong statistic is a likelihood ratio of two unnested models, with a large positive value in favor of the zero-inflated model and a large negative value in favor of the other.

We discuss the results of the ZINBPML models for each groundnut product separately. Table 8 reports the results for edible groundnuts. The MRL shows a moderate volume-promoting effect but has no impact on new market access. A larger European income increases Africa’s propensity to export but decreases trade volumes, indicating the inferior good attribute of African edible groundnuts as in the HMR approach. A more abundant African supply enhances the trade flows, with an unexpected negative effect on the probability to trade, but only statistically significant at $10 \%$ level. The huge positive distance effect on trade flows is unexpected and we address this concern in the model selection part in Section 5.

Table 9 reports the results for the sector of shelled groundnuts. The MRL remains insignificant to African exports. African domestic supply remains a robust trade determinant. The puzzling distance effect on market access is to be discussed next, together with that of the sector of edible groundnuts. A common language seems to ease trade creation but impede trade 
volumes, which suggests that although affecting the fixed cost to trade significantly, the effect of common language on the existing exporters can be controversial. The results of the ZINBPML model for groundnut oil, shown in Table 10, echo those of the HMR model. The MRL doesn't seem to affect African exports, either in terms of market access or trade volumes. A larger EU income increases the chance of trade. A boosted African supply facilitates both the creation and the intensification of trade. A longer distance lowers the probability of trade, and its effect on the trade volumes, in terms of elasticity, is around -6.8, close to the upper bound reported in Hummels (2001).

\section{Model Selection and Summary of Trade Effects of MRLs}

In this section, we first select a most preferred model based on the various statistical tests performed in section 4 and also using economic theory. Next, we provide a summary of the groundnut trade effects of the MRL set by the EU. In addition, several robust checks are conducted to ensure the associated econometric results can be used for policy analysis. Table 11 summarizes the model selection strategy.

Table 11: Model selection for all three products

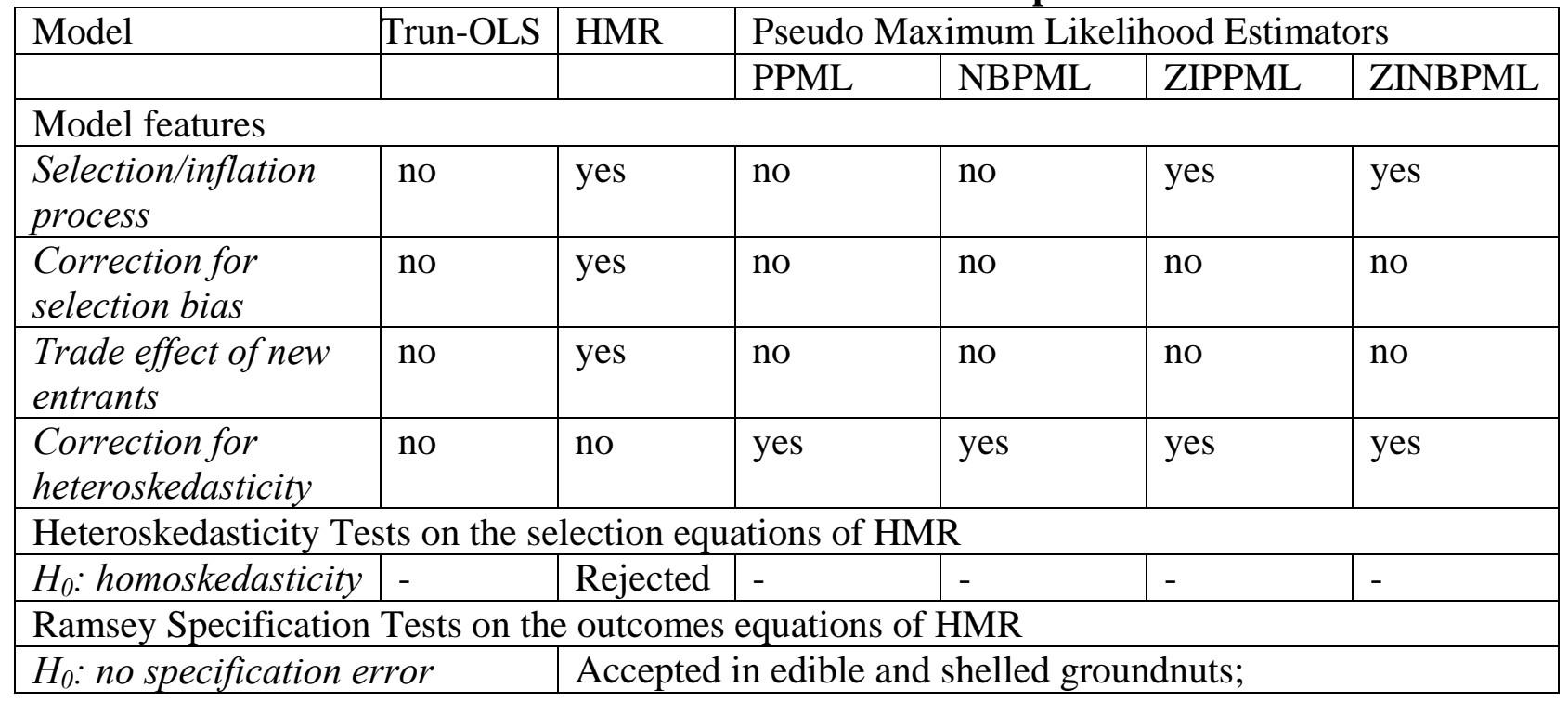




\begin{tabular}{|l|l|l|l|l|l|}
\hline \multicolumn{5}{|c|}{ Rejected for groundnut oil } \\
\hline Tests on the family of Pseudo Maximum Likelihood estimators \\
\hline Dispersion test & - & - & PPML $\prec$ NBPML & ZIPPML $\prec$ ZINBPML \\
\hline Vuong test & - & - & & PPML $\prec$ ZIPPML & - \\
\cline { 3 - 6 } & & & - & \multicolumn{3}{|c|}{ NBPML $\prec$ ZINBPML } \\
\hline
\end{tabular}

We choose the most preferable model via the elimination of the dominated models. First of all, the Truncated OLS model is considered inferior to others because of its inability to address new market access, its potential biasness from sample selection, and vulnerability to heteroskedasticity. Secondly, the dispersion and Vuong tests lead to the ZINBPML model as the most suited model within the family of pseudo maximum likelihood estimators for all three groundnut products. Therefore, the model choice boils down to the comparison between the HMR model and the ZINBPML model. As Table 11 shows, the HMR model has the advantages of correcting for the potential sample selection bias, that is, the information one can infer about the trade volume once we know an exporter decides to export to a destination; and modeling the trade effect of newly entrants to the export market in a theoretically rigorous and econometrically applicable way. However, the ZINBPML model is robust to heteroskedascity in trade flows, commonly found in disaggregated trade data. In fact, there are no existing statistical methods or economic theories to distinguish the two models methodologically, suggesting that the choice between HMR and ZINBPML is purely application-specific. ${ }^{20}$ In our context, since strong evidence of the mis-specification of the firms' margin and some evidence of the biasness due to logarithmic transformation are found, we consider the ZINBPML model to be slightly preferable over the HMR, although we recognize the somewhat arbitrary nature of the latter. Nevertheless, we make use of the results in both the HMR models and the ZINBPML models to summarize the

\footnotetext{
${ }^{20}$ Ideally, a zero-inflated Poisson or Negative Binomial model with the correction for sample selection bias is most desirable. Given the current stage of econometric advancement, it is difficult to implement with its strong nonlinearity (Greene (1994)).
} 
trade effects of EU MRLs on African groundnut exports, which are shown in Table 12.

Table 12: The impact of the EU MRL on groundnut exports from Africa

\begin{tabular}{|l|l|c|c|c|}
\hline \multicolumn{2}{|c|}{} & $\begin{array}{c}\text { Edible } \\
\text { groundnut }\end{array}$ & $\begin{array}{c}\text { Shelled } \\
\text { groundnut }\end{array}$ & Groundnut oil \\
\hline \multirow{3}{*}{ HMR } & Extensive Margin & -0.165 & -0.030 & 0.759 \\
\cline { 2 - 5 } & Existing Firms' Margin & -0.408 & 0.031 & 1.006 \\
\cline { 2 - 5 } & New Firms' Margin & -0.096 & -0.011 & 0.221 \\
\hline \multirow{2}{*}{ ZINBPML } & Extensive Margin & -0.305 & -0.129 & 1.831 \\
\cline { 2 - 5 } & Intensive Margin & $-0.697^{*}$ & 0.248 & 1.034 \\
\hline
\end{tabular}

Notes: Margins are defined as in Table 6, and 8-10. *. Significance levels indicated as in previous tables: ${ }^{*} \mathrm{p}<0.10$, $* * \mathrm{p}<0.05,{ }^{* * *} \mathrm{p}<0.01$.

Table 12 shows that the trade effects of EU MRLs on African groundnut exports are insignificant among the two preferred models and across three groundnut products, with one exception where the MRL seems to have promoted African exports of edible groundnuts. With this estimated elasticity of -0.697 , we further simulate how much would the average trade level be for 2002-2006 if the EU harmonization in MRLs didn't occur. The result shows that Africa's export revenue in the sector edible groundnuts would be lower by US $\$ 224,800$ if the preharmonized MRL policies remained. Therefore and in contrast to the previously acknowledged standards-as-barriers argument for the EU's regulations on aflatoxins, our findings suggest that the trade effect of the EU's MRL policy on aflatoxin contaminants in groundnuts is null or at best ambiguous, and certainly not impeding. Neither the propensity to create new trade partnership nor the volume exported to the existing trade partners is found to be significantly influenced by the MRL in most cases.

We also summarize trade effects of the other gravity variables in the two preferred models. A larger European GDP tends to increase the Africa's propensity to export edible groundnuts and groundnut oil. However, this income effect is negative on the quantity traded in edible groundnuts, suggesting the possibility that EU consumers view edible groundnuts from 
Africa as inferior. African domestic supply proves to be a crucial trade determinant: a boosted domestic supply increases both the chance of trade and the volumes traded in all three groundnut products, with only one exception: a negative impact is detected, marginally statistically significant at $10 \%$ level, on the probability of trade in edible groundnuts in the ZINBPML model. The distance effect for edible groundnuts trade exhibits sign reversal in the two preferred models, indicating the importance of controlling for both the heteroskedasticity and the trade effects of newly entered exporting firms when analyzing the sector of edible groundnuts (See footnote 15). A longer distance decreases both the likelihood of trade and the quantity traded in groundnut oil. The distance effect in the sector of shelled groundnuts is unexpected: it slightly impedes trade volumes but encourages the creation of new trade significantly. This counterintuitive result suggests that the geographic distance between countries might not be a good proxy for the transportation cost in Africa-EU shelled groundnut trade. We investigated alternative specifications with interaction terms with other transaction cost variables. The problem was slightly attenuated but did not disappear. Other variable costs such as the distance by sea and/or infrastructure facilities could be considered in further research.

A common language has no significant effect on the probability of trade, except for shelled groundnuts; its effect on trade volumes is controversial: trade-promoting for groundnut oil but trade-impeding for shelled groundnut. However, this controversy is reconciled if the interest is in the role of common language on the total trade value in all three products: the Africa-EU trade value in the sector of groundnut oil is nearly five times larger than the sector of shelled groundnuts on average, so the net effect of common language on the total trade value remains positive. The variable may confound the change in the trade composition and the trade facilitating aspects of a common language. 
Before concluding our analysis, we address the potential endogeneity of the African supply variable, which is constructed as each African country's total exports to the rest of the world. The simultaneity of trade and output determination is a common problem in the applied trade literature. Several fixes have been recommended. Harrigan (1994) suggests using factor endowments as the instrumental variables for the output, and estimate the model by two-stage Least Square. However, our application is so disaggregated that it would be difficult to find a valid factor endowment instrument. Another remedy is simply to constrain the coefficient of the supply to be one, or in other words let the share of exports be the dependent variable. The disadvantage of this fix is that we would not able to infer how important the domestic capacity is to the export potential of Africa. The approach we take to address the endogeneity is to construct an alternative African supply proxy from the FAOSTAT database. The database provides food supply series for a wide range of agricultural commodities and countries. For each of the nine African countries, we extract "groundnut oil,” "groundnuts (in shell equivalence),” and “groundnuts (shelled equivalence)” as the alternative supply series for groundnut oil, shelled groundnuts, and edible groundnuts respectively. This alternative African supply is considered exogenous to the bilateral trade flows. With this alternative supply proxy, we re-do all of the models and repeat the model selection process ${ }^{21}$. The ZINBPML model again stands out as the most preferable one among four pseudo maximum likelihood estimators. Within the two preferred models, HMR and ZINBPML, ${ }^{22}$ all trade effects of MRLs are not significant except for one from ZINBPML, suggesting MRL marginally decrease Africa’s propensity to export groundnut oil, with a significance level of $10 \%$.

\footnotetext{
${ }^{21}$ The associated results are available from authors upon request.

${ }^{22}$ For the sector of groundnut oil, the second step of the HMR model suffers from convergence problems. Hence, the impact of MRLs on the trade volumes of groundnut oil is inferred from the ZINBPML model only.
} 


\section{Conclusion}

As traditional trade barriers such as tariffs and quotas have been declining across countries overtime, there has been a concurrent upward trend in the adoption of various food safety standards. Food safety standards are driven by human health and/or environmental concerns, and generally grounded in the risk assessment of specific contaminants in food and feed. Since 1961, the Codex Alimentarius Commission jointly formed by FAO and WHO has been promoting international food safety standards that can serve as “an international reference point.” However, many countries have not adopted these non-binding international standards, but rather have set food safety standards for a wider range of commodities and at a much tighter level than what Codex recommends, which consequently brings the possibility of a protectionist motive.

Our study investigates the 2002 EU's harmonization and tightening of the MRL on aflatoxin contaminants and its impact on groundnut product exports from Africa. We use a stateof-the-art toolkit for gravity equation approaches to investigate the trade effects of these EU's MRL policies on African groundnut exporters. The contribution of our analysis to the literature is triple. First of all, unlike previous econometric analyses of EU aflatoxin policies, our results suggest that the harmonization and tightening of aflatoxin regulations within the EU has no significant effect on African groundnut exports, either in terms of the trade volumes, or the propensity to trade. This empirical result challenges the established view that a stricter food safety standard would act like a barrier to trade.

We offered two rationalizations to interpret the insignificance of the estimated effect of the MRL policy. First and more plausible to us, the food safety policy adopted by the EU is non binding for African groundnut exporters because their export potential is mostly constrained by their domestic capacity, such as farming and storage practice, and/or other barriers before the 
border. Or alternatively, the stringent EU standard both increases the trade costs for exporters from Africa and enhances demand within the EU, due to the quality improvement of the groundnut products such that its overall trade effect is exactly null. We find this a bit farfetched. The second important finding is that domestic groundnut supply conditions in Africa appear to be a binding constraint for its groundnut exports across all methods of estimation. This finding implies that it is the domestic issue rather than the accessibility to the world market that constrains Africa’s export potential. Addressing Africa’s under-trading problem from a development viewpoint might be more helpful than merely improving international accessibility for African traders (Bouët et al. (2008); Rios and Jaffee (2008)). Last, our application highlights the performance of different estimation strategies for the gravity equation model. The omission of the "multilateral resistance" terms induces severe biases to the estimates of interest; the HMR model explains well both the qualitative and quantitative aspects of bilateral trade if the exclusion restriction is satisfied; the PPML estimator is not robust when zero trade flows are pervasive.

Several possible extensions may help better understand the trade effects of the EU's MRL policy on aflatoxin. It is desirable to account for the trade diversion effects of the policy: a tightening of the standard within the EU would encourage African traders to export more to other destinations with looser standards than the EU standards. It would also be interesting to decompose the overall trade effect of the food safety standard into its trade cost effect and demand-enhancing effect, to formerly identify the MRL's respective influence on producers and consumers, rather than a net effect. 


\section{References}

Anderson, James and van Wincoop, Eric. 2003. “Gravity with Gravitas: A Solution to the Border Puzzle,” The American Economic Review 93(1): 170-192.

Anderson, James, and van Wincoop, Eric. 2004. “Trade Costs,” Journal of Economic Literature, Vol. XLII (September): 691-751.

Baier, Scott and Bergstrand, Jeffrey. 2001. “The Growth of World Trade: Tariffs, Transport Costs, and Income Similarity,” Journal of International Economics 53(1): 1-27.

Baldwin, Richard E. and Taglioni, Daria. 2006. “Gravity for Dummies and Dummies for Gravity Equations” (September 2006). CEPR Discussion Paper No. 5850.

Bouët, Antoine, Santosh Mishra and Devesh Roy. 2008. "Does Africa Trade Less than it Should and Why” Helsinki, GTAP Conference and International Food Policy Research Institute, IFPRI discussion paper 770 .

Burger, Martin, van Oort, Frank, and Linders, Gert-Jan. 2009. “On the Specification of the Gravity Model of Trade: Zeros, Excessive Zeros and Zero-Inflated Estimations,” Spatial Economic Analysis, 4(2): 167-190.

Buys, Piet, Uwe Deichmann, and David Wheeler. 2010. “Road Network Upgrading and Overland Trade Expansion in Sub-Saharan Africa,” Journal of African Economies 19(3):399432.

Disdier, Anne-Célia and Head, Keith. 2008. “The Puzzling Persistence of the Distance Effect on Bilateral Trade,” The Review of Economics and Statistics 90(1): 37-48.

European Commission. 2001. Commission Regulation (EC) No 466/2001 of 8 March 2001, Official Journal of the European Communities.

European Commission. 2002. Commission Regulation (EC) No 472/2002 of 12 March 2002, 
Official Journal of the European Communities.

European Commission. 2006. Commission Regulation (EC) No 1881/2006 of 19 December 2006, Official Journal of the European Communities.

FAO (Food and Agricultural Organization). 1995. Worldwide Regulations for Mycotoxins 1995: a Compendium. Rome: FAO.

FAO (Food and Agricultural Organization). 2004. Worldwide Regulations for Mycotoxins in Food and Feed in 2003. Rome: FAO.

Greene, William H. 1994. “Accounting for Excess Zeros and Sample Selection in Poisson and Negative Binomial Regression Models,” NYU Working Paper No. EC-94-10.

Harrigan, James. 1979. "Scale Economies and the Volumes of Trade,” The Review of Economics and Statistics 76(2): 321-328.

Heckman, James. 1979. “Sample Selection Bias as a Specification Error,” Econometrica 47(1): 153-161.

Helpman, Elhanan, Melitz, Marc, and Rubinstein Yona. 2008. “Estimating Trade Flows: Trading Partners and Trading Volumes," Quarterly Journal of Economics 73(2): 441-486.

Henry de Frahan, Bruno, and Vancauteren, Mark. 2006. “Harmonisation of Food Regulations and Trade in the Single Market: Evidence from Disaggregated Data,” European Review of Agricultural Economics 33(3): 337-360.

Hummels, David L. 2001. “Toward a Geography of Trade Costs,” Purdue University. Jaffee, Steve, and Spencer Henson. 2005. “Agro-food Exports from Developing Countries: the Challenges Posed by Standards, Global Agricultural Trade and Developing Countries,” Chapter 6 in Aksoy, M. A., and J. C. Beghin, eds. Global Agricultural Trade \& Developing Countries. The World Bank. 
IFPRI. 2009. “New Project, Funded by a Grant from the Bill \& Melinda Gates Foundation, to Reduce Aflatoxin Contamination of Crops in Kenya and Mali” Pressroom, June 26. http://www.ifpri.org/pressrelease/new-project-funded-grant-bill-melinda-gates-foundationreduce-aflatoxin-contamination-c

Jayasinghe, Sampath, Beghin, John and Moschini, Giancarlo. Forthcoming. "Determinants of World Demand for U.S. Corn Seeds: The Role of Trade Costs,” American Journal of Agricultural Economics.

Maertens, Miet, and Swinnen, Johan F.M. 2009. “Trade, Standards, and Poverty: Evidence from Senegal,” World Development Vol 37(1): 161-178.

Martin, Will and Pham, Cong. 2008. "Estimating the Gravity Model When Zero Trade Flows Are Frequent,” Mimeo, The World Bank.

Maskus, Keith and Wilson, John. 2001. Quantifying the Impact of Technical Barriers to Trade:

Can It Be Done? Ann Arbor, MI: University of Michigan Press.

McCallum, John. 1995. “National Borders Matter: Canada-U.S. Regional Trade Patterns,” The American Economic Review 85(3): 615-623.

Otsuki, Tsunehiro, Wilson, John, and Sewadeh Mirvat. 2001.“What Price Precaution? European Harmonization of Aflatoxin Regulations and African Groundnut Exports,” European Review of Agricultural Economics Vol 28(2): 263-283.

Ramsey, J.B. (1969). “Tests for Specification Errors in Classical Linear Least Squares Regression Analysis,” Journal of the Royal Statistical Society 31(2): 350-371

Rios, L.D., and S. Jaffee. 2008. "Barrier, Catalyst, or Distraction? Standards, Competitiveness, and Africa's Groundnut Exports to Europe." Agriculture and Rural Development Discussion Paper 39, The World Bank, Washington DC. 
Rose, Andrew and van Wincoop, Eric. 2001. "National Money as a Barrier to International

Trade: The Real Case for Currency Union,” The American Economic Review 91(2): 386-390.

Silva, Santos, and Tenreyro, Silvana. 2006. “The Log of Gravity,” The Review of Economics and

Statistics 88(4): 641-658.

Silva, Santos, and Tenreyro, Silvana. 2009. “Trading Partners and Trading Volumes:

Implementing the Helpman-Melitz-Rubinstein Model Empirically,” CEP Discussion Paper, No

935, June 2009. 


\title{
Appendix 1: Full regression results (not intended for publication)
}

\author{
(February $1^{\text {st }}, 2011$ )
}

Table A1-1: Truncated OLS models (sectoral)

\begin{tabular}{|c|c|c|c|}
\hline OLS & $\begin{array}{l}\text { (edible) } \\
\text { ln_Trade }\end{array}$ & $\begin{array}{c}\text { (oil) } \\
\text { ln_Trade }\end{array}$ & $\begin{array}{l}\text { (shelled) } \\
\text { ln_Trade }\end{array}$ \\
\hline \multirow[t]{2}{*}{$M R L$} & -0.556 & 1.139 & -0.0110 \\
\hline & $(-1.53)$ & (1.29) & $(-0.03)$ \\
\hline \multirow[t]{2}{*}{$G D P$} & $-6.667^{* * *}$ & -2.973 & -0.196 \\
\hline & $(-3.35)$ & $(-0.95)$ & $(-0.10)$ \\
\hline \multirow[t]{2}{*}{ Supply } & $0.486^{* * *}$ & $0.827^{* * *}$ & $0.469^{* * *}$ \\
\hline & (3.94) & (8.99) & $(4.42)$ \\
\hline \multirow[t]{2}{*}{ Dist } & -0.477 & $-7.556^{* * *}$ & -1.180 \\
\hline & $(-0.28)$ & $(-3.59)$ & $(-0.90)$ \\
\hline \multirow[t]{2}{*}{ Dlang } & 1.177 & $0.527^{*}$ & $-0.882^{* *}$ \\
\hline & $(1.21)$ & (1.96) & $(-2.58)$ \\
\hline \multirow[t]{2}{*}{ Year89 } & -0.680 & -0.925 & -0.165 \\
\hline & $(-0.56)$ & $(-0.77)$ & $(-0.16)$ \\
\hline \multirow[t]{2}{*}{ Year90 } & $-2.013^{*}$ & -1.229 & 0.627 \\
\hline & $(-1.96)$ & $(-1.11)$ & $(0.63)$ \\
\hline \multirow[t]{2}{*}{ Year91 } & -1.588 & -0.930 & 0.440 \\
\hline & $(-1.52)$ & $(-0.86)$ & $(0.45)$ \\
\hline \multirow[t]{2}{*}{ Year92 } & -1.299 & -0.971 & -0.537 \\
\hline & $(-1.33)$ & $(-0.91)$ & $(-0.55)$ \\
\hline \multirow[t]{2}{*}{ Year93 } & -0.969 & -1.453 & -0.0742 \\
\hline & $(-1.01)$ & $(-1.36)$ & $(-0.08)$ \\
\hline \multirow[t]{2}{*}{ Year94 } & -1.379 & -0.362 & 0.439 \\
\hline & $(-1.56)$ & $(-0.37)$ & $(0.48)$ \\
\hline \multirow[t]{2}{*}{ Year95 } & -0.414 & -0.378 & 0.221 \\
\hline & $(-0.51)$ & $(-0.41)$ & $(0.25)$ \\
\hline \multirow[t]{2}{*}{ Year96 } & -0.901 & -0.766 & -0.237 \\
\hline & $(-0.97)$ & $(-0.86)$ & $(-0.28)$ \\
\hline \multirow[t]{2}{*}{ Year97 } & $-1.423^{*}$ & -0.545 & -0.177 \\
\hline & $(-1.87)$ & $(-0.67)$ & $(-0.22)$ \\
\hline \multirow[t]{2}{*}{ Year98 } & $-1.352^{*}$ & -0.410 & -0.333 \\
\hline & $(-1.77)$ & $(-0.54)$ & $(-0.44)$ \\
\hline \multirow[t]{2}{*}{ Year99 } & -0.649 & -0.431 & -0.266 \\
\hline & $(-0.99)$ & $(-0.56)$ & $(-0.35)$ \\
\hline \multirow[t]{2}{*}{ Year00 } & -0.577 & -0.632 & -0.500 \\
\hline & $(-0.94)$ & $(-0.93)$ & $(-0.71)$ \\
\hline \multirow[t]{2}{*}{ Year01 } & -0.654 & -0.205 & -0.434 \\
\hline & $(-1.06)$ & $(-0.33)$ & $(-0.64)$ \\
\hline \multirow[t]{2}{*}{ Year02 } & -0.443 & 0.166 & -0.0988 \\
\hline & $(-0.73)$ & $(0.28)$ & $(-0.17)$ \\
\hline
\end{tabular}




\begin{tabular}{|c|c|c|c|}
\hline Year03 & $\begin{array}{l}-0.197 \\
(-0.32)\end{array}$ & $\begin{array}{l}-0.215 \\
(-0.34)\end{array}$ & $\begin{array}{l}-0.697 \\
(-1.20)\end{array}$ \\
\hline \multirow[t]{2}{*}{ Year04 } & 0.0745 & -0.808 & -0.0331 \\
\hline & $(0.14)$ & $(-1.34)$ & $(-0.06)$ \\
\hline \multirow[t]{2}{*}{ Year05 } & -0.0390 & 0.0638 & 0.198 \\
\hline & $(-0.07)$ & $(0.09)$ & $(0.34)$ \\
\hline \multirow[t]{2}{*}{$E G Y$} & -1.295 & $-9.384^{* * *}$ & $-2.804^{*}$ \\
\hline & $(-0.66)$ & $(-3.40)$ & $(-1.92)$ \\
\hline \multirow[t]{2}{*}{$G M B$} & 0.0626 & $-5.006^{* * *}$ & -1.246 \\
\hline & $(0.04)$ & $(-3.13)$ & $(-1.18)$ \\
\hline \multirow[t]{2}{*}{$M L I$} & -1.823 & dropped & -0.371 \\
\hline & $(-1.06)$ & & $(-0.27)$ \\
\hline \multirow[t]{2}{*}{$N G A$} & $-2.584^{* *}$ & $-4.262^{* * *}$ & $-2.651^{* *}$ \\
\hline & $(-2.16)$ & $(-2.89)$ & $(-2.41)$ \\
\hline \multirow[t]{2}{*}{$S D N$} & 1.244 & $-5.972^{* * *}$ & -1.299 \\
\hline & $(0.65)$ & $(-3.50)$ & $(-1.29)$ \\
\hline \multirow[t]{2}{*}{ SEN } & -0.415 & $-5.581^{* * *}$ & -1.513 \\
\hline & $(-0.26)$ & $(-3.50)$ & $(-1.37)$ \\
\hline \multirow[t]{2}{*}{$T C D$} & dropped & $-6.599^{* * *}$ & dropped \\
\hline & & $(-3.26)$ & \\
\hline \multirow[t]{2}{*}{$Z W E$} & $-0.986^{*}$ & dropped & $-2.212^{* * *}$ \\
\hline & $(-1.79)$ & & $(-3.48)$ \\
\hline \multirow[t]{2}{*}{$A U T$} & $-15.10^{* * * *}$ & -8.656 & -3.193 \\
\hline & $(-3.86)$ & $(-1.30)$ & $(-0.85)$ \\
\hline \multirow[t]{2}{*}{$B L X$} & $-10.08^{* * *}$ & -6.960 & -1.268 \\
\hline & $(-3.06)$ & $(-1.33)$ & $(-0.39)$ \\
\hline \multirow[t]{2}{*}{ CHE } & $-10.32^{* * *}$ & -5.271 & 1.681 \\
\hline & $(-4.15)$ & $(-1.24)$ & $(0.71)$ \\
\hline \multirow[t]{2}{*}{$D E U$} & $3.620^{* * * *}$ & 0.915 & 0.724 \\
\hline & (4.01) & $(0.70)$ & $(0.85)$ \\
\hline \multirow[t]{2}{*}{$D N K$} & $-5.053^{* * *}$ & $-3.569^{* * *}$ & -1.223 \\
\hline & $(-3.65)$ & $(-3.29)$ & $(-0.99)$ \\
\hline \multirow[t]{2}{*}{$E S P$} & $-4.655^{* * *}$ & $-12.73^{* * *}$ & -0.652 \\
\hline & $(-2.78)$ & $(-4.26)$ & $(-0.38)$ \\
\hline \multirow[t]{2}{*}{ FIN } & $-19.73^{* * *}$ & dropped & -1.054 \\
\hline & $(-4.13)$ & & $(-0.23)$ \\
\hline \multirow[t]{2}{*}{$G B R$} & $-2.374^{*}$ & -1.901 & $2.028^{* *}$ \\
\hline & $(-1.87)$ & $(-1.15)$ & $(2.32)$ \\
\hline \multirow[t]{2}{*}{$I R L$} & $-20.76^{* * * *}$ & dropped & -3.363 \\
\hline & $(-3.93)$ & & $(-0.65)$ \\
\hline \multirow[t]{2}{*}{$I T A$} & -0.177 & -0.684 & $1.673^{*}$ \\
\hline & $(-0.25)$ & $(-1.01)$ & (1.96) \\
\hline \multirow[t]{2}{*}{$N L D$} & $-6.824^{* * *}$ & -6.391 & 0.937 \\
\hline & $(-2.72)$ & $(-1.59)$ & $(0.38)$ \\
\hline \multirow[t]{2}{*}{$P R T$} & dropped & $-18.14^{* *}$ & -1.918 \\
\hline & & $(-2.26)$ & $(-0.40)$ \\
\hline
\end{tabular}




\begin{tabular}{lccc} 
SWE & -0.525 & -1.653 & -2.604 \\
& $(-0.40)$ & $(-1.04)$ & $(-1.16)$ \\
Cons & $187.8^{* * *}$ & 145.2 & 14.55 \\
& $(3.26)$ & $(1.60)$ & $(0.26)$ \\
\hline Obs & 287 & 231 & 462 \\
$R^{2}$ & 0.578 & 0.827 & 0.480 \\
\hline
\end{tabular}

Notes: $t$ statistics in parentheses; ${ }^{*} p<0.10,{ }^{* *} p<0.05,{ }^{* * *} p<0.01$; some country dummies are dropped because they don't export or import at all for a particular groundnut product.

Table A1-2: Robust regression models (sectoral)

\begin{tabular}{|c|c|c|c|}
\hline Robust Reg. & $\begin{array}{l}\text { (edible) } \\
\text { ln_Trade }\end{array}$ & $\begin{array}{c}\text { (oil) } \\
\text { ln_Trade }\end{array}$ & $\begin{array}{l}\text { (shelled) } \\
\text { ln_Trade }\end{array}$ \\
\hline \multirow[t]{2}{*}{$M R L$} & $-0.600^{*}$ & 1.252 & -0.0276 \\
\hline & $(-1.67)$ & $(1.46)$ & $(-0.08)$ \\
\hline \multirow[t]{2}{*}{$G D P$} & $-6.673^{* * *}$ & -2.437 & -0.390 \\
\hline & $(-3.37)$ & $(-0.81)$ & $(-0.21)$ \\
\hline \multirow[t]{2}{*}{ Supply } & $0.491^{* * *}$ & $0.824^{* * *}$ & $0.467^{* * *}$ \\
\hline & $(4.01)$ & (9.27) & $(4.58)$ \\
\hline \multirow[t]{2}{*}{ Dist } & -0.586 & $-7.541^{* * *}$ & -1.101 \\
\hline & $(-0.34)$ & $(-3.71)$ & $(-0.87)$ \\
\hline \multirow[t]{2}{*}{ Dlang } & 1.193 & $0.534^{* *}$ & $-0.943^{* * *}$ \\
\hline & (1.23) & $(2.05)$ & $(-2.86)$ \\
\hline \multirow[t]{2}{*}{ Year89 } & -0.659 & -0.774 & -0.294 \\
\hline & $(-0.54)$ & $(-0.67)$ & $(-0.29)$ \\
\hline \multirow[t]{2}{*}{ Year90 } & $-1.987^{*}$ & -1.026 & 0.455 \\
\hline & $(-1.95)$ & $(-0.96)$ & $(0.47)$ \\
\hline \multirow[t]{2}{*}{ Year91 } & -1.575 & -0.751 & 0.289 \\
\hline & $(-1.52)$ & $(-0.72)$ & $(0.31)$ \\
\hline \multirow[t]{2}{*}{ Year92 } & -1.307 & -0.804 & -0.696 \\
\hline & $(-1.35)$ & $(-0.78)$ & $(-0.74)$ \\
\hline \multirow[t]{2}{*}{ Year93 } & -0.983 & -1.113 & -0.172 \\
\hline & $(-1.03)$ & $(-1.08)$ & $(-0.18)$ \\
\hline \multirow[t]{2}{*}{ Year94 } & -1.387 & -0.213 & 0.327 \\
\hline & $(-1.58)$ & $(-0.22)$ & $(0.37)$ \\
\hline \multirow[t]{2}{*}{ Year95 } & -0.406 & -0.278 & 0.125 \\
\hline & $(-0.50)$ & $(-0.31)$ & $(0.15)$ \\
\hline \multirow[t]{2}{*}{ Year96 } & -0.864 & -0.633 & -0.348 \\
\hline & $(-0.93)$ & $(-0.73)$ & $(-0.43)$ \\
\hline \multirow[t]{2}{*}{ Year97 } & $-1.395^{*}$ & -0.443 & 0.00400 \\
\hline & $(-1.84)$ & $(-0.57)$ & $(0.01)$ \\
\hline \multirow[t]{2}{*}{ Year98 } & $-1.318^{*}$ & -0.325 & -0.390 \\
\hline & $(-1.74)$ & $(-0.44)$ & $(-0.54)$ \\
\hline \multirow[t]{2}{*}{ Year99 } & -0.643 & -0.407 & -0.363 \\
\hline & $(-0.99)$ & $(-0.55)$ & $(-0.50)$ \\
\hline \multirow[t]{2}{*}{ Year00 } & -0.491 & -0.491 & -0.573 \\
\hline & $(-0.80)$ & $(-0.75)$ & $(-0.84)$ \\
\hline Year01 & -0.576 & 0.0117 & -0.482 \\
\hline
\end{tabular}




\begin{tabular}{|c|c|c|c|}
\hline & $(-0.94)$ & $(0.02)$ & $(-0.73)$ \\
\hline \multirow[t]{2}{*}{ Year02 } & -0.420 & 0.172 & -0.134 \\
\hline & $(-0.69)$ & $(0.30)$ & $(-0.23)$ \\
\hline \multirow[t]{2}{*}{ Year03 } & -0.202 & -0.196 & -0.644 \\
\hline & $(-0.33)$ & $(-0.32)$ & $(-1.15)$ \\
\hline \multirow[t]{2}{*}{ Year04 } & 0.0761 & -0.749 & -0.0885 \\
\hline & $(0.14)$ & $(-1.29)$ & $(-0.16)$ \\
\hline \multirow[t]{2}{*}{ Year05 } & -0.0279 & 0.0665 & 0.182 \\
\hline & $(-0.05)$ & $(0.10)$ & $(0.33)$ \\
\hline \multirow[t]{2}{*}{$E G Y$} & -1.356 & $-9.587^{* * *}$ & $-2.871^{* *}$ \\
\hline & $(-0.69)$ & $(-3.60)$ & $(-2.04)$ \\
\hline \multirow[t]{2}{*}{$G M B$} & 0.00714 & $-5.113^{* * *}$ & -1.315 \\
\hline & $(0.00)$ & $(-3.31)$ & $(-1.30)$ \\
\hline \multirow[t]{2}{*}{$M L I$} & -1.907 & dropped & -0.396 \\
\hline & $(-1.12)$ & & $(-0.30)$ \\
\hline \multirow[t]{2}{*}{$N G A$} & $-2.615^{* *}$ & $-4.370^{* * *}$ & $-2.659^{* *}$ \\
\hline & $(-2.20)$ & $(-3.07)$ & $(-2.51)$ \\
\hline \multirow[t]{2}{*}{$S D N$} & 1.164 & $-6.085^{* * *}$ & -1.374 \\
\hline & $(0.61)$ & $(-3.70)$ & $(-1.41)$ \\
\hline \multirow[t]{2}{*}{ SEN } & -0.481 & $-5.696^{* * *}$ & -1.570 \\
\hline & $(-0.31)$ & $(-3.70)$ & $(-1.47)$ \\
\hline \multirow[t]{2}{*}{$T C D$} & dropped & $-6.769^{* * *}$ & dropped \\
\hline & & $(-3.46)$ & \\
\hline \multirow[t]{2}{*}{$Z W E$} & $-1.026^{*}$ & dropped & $-2.285^{* * *}$ \\
\hline & $(-1.87)$ & & $(-3.73)$ \\
\hline \multirow[t]{2}{*}{$A U T$} & $-15.04^{* * *}$ & -7.541 & -3.535 \\
\hline & $(-3.87)$ & $(-1.18)$ & $(-0.98)$ \\
\hline \multirow[t]{2}{*}{$B L X$} & $-10.03^{* * *}$ & -6.059 & -1.679 \\
\hline & $(-3.06)$ & $(-1.20)$ & $(-0.54)$ \\
\hline \multirow[t]{2}{*}{ CHE } & $-10.33^{* * *}$ & -4.500 & 1.866 \\
\hline & $(-4.18)$ & $(-1.10)$ & $(0.82)$ \\
\hline \multirow[t]{2}{*}{$D E U$} & $3.663^{* * *}$ & 0.824 & 0.768 \\
\hline & $(4.08)$ & $(0.65)$ & $(0.94)$ \\
\hline \multirow[t]{2}{*}{$D N K$} & $-5.020^{* * *}$ & $-3.405^{* * *}$ & -1.247 \\
\hline & $(-3.65)$ & $(-3.25)$ & $(-1.05)$ \\
\hline \multirow[t]{2}{*}{$E S P$} & $-4.603^{* * *}$ & $-12.23^{* * *}$ & -0.815 \\
\hline & $(-2.77)$ & $(-4.24)$ & $(-0.49)$ \\
\hline \multirow[t]{2}{*}{ FIN } & $-19.77^{* * *}$ & dropped & -1.595 \\
\hline & $(-4.16)$ & & $(-0.36)$ \\
\hline \multirow[t]{2}{*}{$G B R$} & $-2.306^{*}$ & -1.613 & $1.960^{* *}$ \\
\hline & $(-1.83)$ & $(-1.01)$ & (2.33) \\
\hline \multirow[t]{2}{*}{$I R L$} & $-20.73^{* * *}$ & dropped & -3.954 \\
\hline & $(-3.94)$ & & $(-0.79)$ \\
\hline \multirow[t]{2}{*}{$I T A$} & -0.132 & -0.591 & $1.763^{* *}$ \\
\hline & $(-0.19)$ & $(-0.90)$ & $(2.15)$ \\
\hline$N L D$ & $-6.733^{* * *}$ & -5.582 & 0.685 \\
\hline
\end{tabular}




\begin{tabular}{lccc} 
& $(-2.70)$ & $(-1.43)$ & $(0.29)$ \\
PRT & dropped & $-16.94^{* *}$ & -2.266 \\
& & $(-2.19)$ & $(-0.49)$ \\
SWE & -0.510 & -1.833 & -2.473 \\
& $(-0.39)$ & $(-1.20)$ & $(-1.15)$ \\
Cons & $188.8^{* * *}$ & 130.0 & 19.49 \\
& $(3.30)$ & $(1.48)$ & $(0.37)$ \\
\hline Obs & 287 & 231 & 462 \\
\hline
\end{tabular}

Notes: $t$ statistics in parentheses; ${ }^{*} p<0.10,{ }^{* *} p<0.05,{ }^{* * *} p<0.01$; some country dummies are dropped because they don't export or import at all for a particular groundnut product.

Table A1-3: Truncated OLS model (pooled)

\begin{tabular}{|c|c|c|c|}
\hline OLS & $\begin{array}{l}\text { (edible) } \\
\text { ln_Trade }\end{array}$ & $\begin{array}{c}(\text { oil })^{\mathrm{a}} \\
\text { ln_Trade }\end{array}$ & $\begin{array}{l}\text { (shelled) } \\
\text { ln_Trade }\end{array}$ \\
\hline$M R L$ & $\begin{array}{c}-0.556 * \\
(-1.71)\end{array}$ & $\begin{array}{l}1.139 \\
(1.81)\end{array}$ & $\begin{array}{c}-0.0110 \\
(0.00)\end{array}$ \\
\hline$G D P$ & $\begin{array}{c}-6.667^{* * *} \\
(-3.22)\end{array}$ & $\begin{array}{c}-2.973 \\
(0.95)\end{array}$ & $\begin{array}{c}-0.196 \\
(0.02)\end{array}$ \\
\hline Supply & $\begin{array}{c}0.486^{* * *} \\
(4.14)\end{array}$ & $\begin{array}{c}0.827^{* * *} \\
(79.39)\end{array}$ & $\begin{array}{c}0.469^{* * *} \\
(19.78)\end{array}$ \\
\hline Dist & $\begin{array}{l}-0.477 \\
(-0.25)\end{array}$ & $\begin{array}{c}-7.556^{* * *} \\
(18.86)\end{array}$ & $\begin{array}{c}-1.180 \\
(0.50)\end{array}$ \\
\hline Dlang & $\begin{array}{l}1.177 * \\
(1.81)\end{array}$ & $\begin{array}{l}0.527^{*} \\
(4.02)\end{array}$ & $\begin{array}{c}-0.882^{* * *} \\
(7.23)\end{array}$ \\
\hline Year89 & $\begin{array}{l}-0.680 \\
(-0.64)\end{array}$ & $\begin{array}{l}-0.925 \\
(0.75)\end{array}$ & $\begin{array}{l}-0.165 \\
(0.02)\end{array}$ \\
\hline Year90 & $\begin{array}{l}-2.013^{* *} \\
(-1.98)\end{array}$ & $\begin{array}{l}-1.229 \\
(1.40)\end{array}$ & $\begin{array}{c}0.627 \\
(0.34)\end{array}$ \\
\hline Year91 & $\begin{array}{l}-1.588 \\
(-1.45)\end{array}$ & $\begin{array}{l}-0.930 \\
(0.84)\end{array}$ & $\begin{array}{l}0.440 \\
(0.17)\end{array}$ \\
\hline Year92 & $\begin{array}{l}-1.299 \\
(-1.27)\end{array}$ & $\begin{array}{l}-0.971 \\
(1.16)\end{array}$ & $\begin{array}{l}-0.537 \\
(0.25)\end{array}$ \\
\hline Year93 & $\begin{array}{l}-0.969 \\
(-1.05)\end{array}$ & $\begin{array}{l}-1.453 \\
(2.21)\end{array}$ & $\begin{array}{c}-0.0742 \\
(0.00)\end{array}$ \\
\hline Year94 & $\begin{array}{l}-1.379^{*} \\
(-1.81)\end{array}$ & $\begin{array}{l}-0.362 \\
(0.17)\end{array}$ & $\begin{array}{l}0.439 \\
(0.19)\end{array}$ \\
\hline Year95 & $\begin{array}{l}-0.414 \\
(-0.63)\end{array}$ & $\begin{array}{l}-0.378 \\
(0.22)\end{array}$ & $\begin{array}{l}0.221 \\
(0.05)\end{array}$ \\
\hline Year96 & $\begin{array}{l}-0.901 \\
(-1.14)\end{array}$ & $\begin{array}{l}-0.766 \\
(1.00)\end{array}$ & $\begin{array}{l}-0.237 \\
(0.06)\end{array}$ \\
\hline Year97 & $\begin{array}{c}-1.423^{* *} \\
(-2.10)\end{array}$ & $\begin{array}{l}-0.545 \\
(0.61)\end{array}$ & $\begin{array}{l}-0.177 \\
(0.03)\end{array}$ \\
\hline Year98 & $\begin{array}{c}-1.352^{* *} \\
(-2.00)\end{array}$ & $\begin{array}{l}-0.410 \\
(0.37)\end{array}$ & $\begin{array}{l}-0.333 \\
(0.13)\end{array}$ \\
\hline Year99 & $\begin{array}{l}-0.649 \\
(-1.07)\end{array}$ & $\begin{array}{l}-0.431 \\
(0.43)\end{array}$ & $\begin{array}{l}-0.266 \\
(0.09)\end{array}$ \\
\hline
\end{tabular}




\begin{tabular}{|c|c|c|c|}
\hline Year00 & $\begin{array}{l}-0.577 \\
(-0.93)\end{array}$ & $\begin{array}{l}-0.632 \\
(0.85)\end{array}$ & $\begin{array}{l}-0.500 \\
(0.34)\end{array}$ \\
\hline \multirow[t]{2}{*}{ Year01 } & -0.654 & -0.205 & -0.434 \\
\hline & $(-1.00)$ & $(0.11)$ & $(0.25)$ \\
\hline \multirow[t]{2}{*}{ Year02 } & -0.443 & 0.166 & -0.0988 \\
\hline & $(-0.81)$ & $(0.14)$ & $(0.03)$ \\
\hline \multirow[t]{2}{*}{ Year03 } & -0.197 & -0.215 & -0.697 \\
\hline & $(-0.42)$ & $(0.18)$ & $(1.21)$ \\
\hline \multirow[t]{2}{*}{ Year04 } & 0.0745 & -0.808 & -0.0331 \\
\hline & $(0.15)$ & (2.39) & $(0.00)$ \\
\hline \multirow[t]{2}{*}{ Year05 } & -0.0390 & 0.064 & 0.198 \\
\hline & $(-0.08)$ & $(0.01)$ & $(0.14)$ \\
\hline \multirow[t]{2}{*}{$E G Y$} & -1.295 & $-9.384^{* * *}$ & -2.804 \\
\hline & $(-0.61)$ & (18.29) & $(2.40)$ \\
\hline \multirow[t]{2}{*}{$G M B$} & 0.0626 & $-5.006^{* * *}$ & -1.246 \\
\hline & $(0.04)$ & (12.95) & $(0.91)$ \\
\hline \multirow[t]{2}{*}{$M L I$} & -1.823 & dropped & -0.371 \\
\hline & $(-1.08)$ & & $(0.05)$ \\
\hline \multirow[t]{2}{*}{$N G A$} & $-2.584^{* *}$ & $-4.262^{* * *}$ & $-2.651^{*}$ \\
\hline & $(-1.97)$ & (11.05) & (3.64) \\
\hline \multirow[t]{2}{*}{$S D N$} & 1.244 & $-5.972^{* * *}$ & -1.299 \\
\hline & $(0.83)$ & $(14.41)$ & (1.07) \\
\hline \multirow[t]{2}{*}{ SEN } & -0.415 & $-5.581^{* * *}$ & -1.513 \\
\hline & $(-0.28)$ & (16.37) & $(1.25)$ \\
\hline \multirow[t]{2}{*}{$T C D$} & $-6.599^{* * *}$ & dropped & dropped \\
\hline & $(-3.81)$ & & \\
\hline \multirow[t]{2}{*}{$Z W E$} & $-0.986^{* *}$ & dropped & $-2.212^{* * *}$ \\
\hline & $(-2.06)$ & & (12.57) \\
\hline \multirow[t]{2}{*}{$A U T$} & $-15.10^{* * *}$ & -8.656 & -3.193 \\
\hline & $(-3.74)$ & $(1.72)$ & $(1.23)$ \\
\hline \multirow[t]{2}{*}{$B L X$} & $-10.08^{* * *}$ & -6.960 & -1.268 \\
\hline & $(-2.90)$ & (1.87) & $(0.27)$ \\
\hline \multirow[t]{2}{*}{ CHE } & $-10.32^{* * *}$ & -5.271 & 1.681 \\
\hline & $(-3.98)$ & (1.54) & $(0.73)$ \\
\hline \multirow[t]{2}{*}{$D E U$} & $3.620^{* * *}$ & 0.915 & 0.724 \\
\hline & (3.95) & $(0.60)$ & $(0.81)$ \\
\hline \multirow[t]{2}{*}{$D N K$} & $-5.053^{* * *}$ & $-3.569^{* * *}$ & -1.223 \\
\hline & $(-3.14)$ & (11.63) & $(0.57)$ \\
\hline \multirow[t]{2}{*}{$E S P$} & $-4.655^{* * *}$ & $-12.73^{* * *}$ & -0.652 \\
\hline & $(-2.62)$ & (19.19) & $(0.26)$ \\
\hline \multirow[t]{2}{*}{$F I N$} & $-19.73^{* * *}$ & dropped & -1.054 \\
\hline & $(-4.00)$ & & $(0.09)$ \\
\hline \multirow[t]{2}{*}{$G B R$} & $-2.374^{* *}$ & -1.901 & $2.028^{* * *}$ \\
\hline & $(-2.19)$ & $(1.26)$ & (8.50) \\
\hline \multirow[t]{2}{*}{$I R L$} & $-20.76^{* * *}$ & dropped & -3.363 \\
\hline & $(-3.74)$ & & $(0.71)$ \\
\hline
\end{tabular}




\begin{tabular}{lccc}
$I T A$ & -0.177 & -0.684 & $1.673^{*}$ \\
& $(-0.27)$ & $(1.24)$ & $(2.95)$ \\
NLD & $-6.824^{* * *}$ & -6.391 & 0.937 \\
& $(-2.59)$ & $(2.56)$ & $(0.26)$ \\
& -1.918 & $-18.14^{* *}$ & dropped \\
SWE & $(-0.55)$ & $(5.84)$ & \\
& -0.525 & -1.653 & $-2.604^{* *}$ \\
Cons & $(-0.38)$ & $(1.38)$ & $(5.34)$ \\
& $187.8^{* * *}$ & $145.2^{*}$ & 14.55 \\
\hline Obs & $(3.09)$ & $(2.71)$ & $(0.10)$ \\
$R^{2}$ & & 980 & \\
\hline
\end{tabular}

Notes: a. The sector of edible groundnut is chosen as the baseline product in the pooled regression. The estimates reported in the columns of groundnut oil and shelled groundnuts are computed as the sums of the main effects and the effects interacting with the product dummy variables. The associated F-statistics of Wald's tests are reported in parentheses for the columns of groundnut oil and shelled groundnuts. $t$ statistics in parentheses for the column of edible groundnuts; ${ }^{*} p<0.10,{ }^{* *} p<0.05,{ }^{* * *} p<0.01$; some country dummies are dropped because they don't export or import at all for a particular groundnut product.

Table A1-4: First-stage of HMR (Probit) models (sectoral)

\begin{tabular}{lccc}
\hline Probit & (edible) & (oil) & (shelled) \\
MRL & $\ln$ (Prob of trade) & $\ln ($ Prob of trade) & $\ln$ (Prob of trade) \\
GDP & -0.165 & 0.759 & -0.0301 \\
& $(-1.08)$ & $(1.19)$ & $(-0.24)$ \\
Supply & $1.156^{* * *}$ & $1.602^{* * *}$ & 0.820 \\
& $(3.26)$ & $(3.88)^{* *}$ & $(1.35)$ \\
Dist & $0.0733^{* *}$ & $0.272^{* * *}$ & $0.363^{* * *}$ \\
& $(2.11)$ & $(6.29)^{* * *}$ & $(9.13)$ \\
Dlang & $1.268^{* * *}$ & $-1.634^{* * *}$ & $0.699^{* *}$ \\
& $(3.06)$ & $(-2.63)$ & $(2.51)$ \\
Dcol & -0.264 & -0.0457 & 0.122 \\
& $(-0.94)$ & $(-0.18)$ & $(0.64)$ \\
Year89 & $0.913^{* * *}$ & 0.288 & $1.202^{* * *}$ \\
& $(2.83)$ & $(0.99)$ & $(4.95)$ \\
Year90 & -0.385 & $1.816^{* * *}$ & 0.381 \\
& $(-1.05)$ & $(4.14)$ & $(1.03)$ \\
Year91 & 0.127 & $1.457^{* * *}$ & 0.185 \\
& $(0.39)$ & $(3.36)$ & $(0.51)$ \\
Year92 & 0.187 & $1.130^{* *}$ & 0.192 \\
& $(0.58)$ & $(2.54)$ & $(0.54)$ \\
Year93 & -0.231 & $1.222^{* * *}$ & -0.0820 \\
& $(-0.72)$ & $(2.77)$ & $(-0.23)$ \\
Year94 & 0.0147 & $0.995^{* *}$ & -0.124 \\
Year95 & $(0.05)$ & $(2.14)$ & $(-0.34)$ \\
& 0.204 & $1.084^{* *}$ & 0.423 \\
& $(0.69)$ & $(2.49)$ & $(1.25)$ \\
& 0.0816 & $1.657^{* * *}$ & 0.0831 \\
& & &
\end{tabular}




\begin{tabular}{|c|c|c|c|}
\hline & $(0.28)$ & (3.88) & $(0.25)$ \\
\hline \multirow[t]{2}{*}{ Year96 } & $-0.540^{*}$ & $0.787^{*}$ & 0.371 \\
\hline & $(-1.72)$ & $(1.81)$ & (1.17) \\
\hline \multirow[t]{2}{*}{ Year97 } & 0.100 & $1.300^{* * *}$ & 0.270 \\
\hline & $(0.36)$ & $(3.08)$ & $(0.88)$ \\
\hline \multirow[t]{2}{*}{ Year98 } & -0.244 & $1.079^{* * *}$ & 0.126 \\
\hline & $(-0.83)$ & $(2.58)$ & $(0.43)$ \\
\hline \multirow[t]{2}{*}{ Year99 } & 0.204 & 0.503 & 0.242 \\
\hline & $(0.77)$ & (1.15) & $(0.84)$ \\
\hline \multirow[t]{2}{*}{ Year00 } & 0.0224 & $0.840^{*}$ & 0.0446 \\
\hline & $(0.08)$ & (1.95) & $(0.16)$ \\
\hline \multirow[t]{2}{*}{ Year01 } & -0.0270 & $1.122^{* * *}$ & 0.0508 \\
\hline & $(-0.10)$ & $(2.71)$ & $(0.19)$ \\
\hline \multirow[t]{2}{*}{ Year02 } & -0.164 & $1.182^{* * *}$ & -0.127 \\
\hline & $(-0.63)$ & (2.89) & $(-0.51)$ \\
\hline \multirow[t]{2}{*}{ Year03 } & -0.124 & $0.795^{*}$ & 0.346 \\
\hline & $(-0.46)$ & $(1.87)$ & (1.39) \\
\hline \multirow[t]{2}{*}{ Year04 } & 0.232 & $1.014^{* *}$ & 0.174 \\
\hline & $(0.91)$ & $(2.47)$ & $(0.71)$ \\
\hline \multirow[t]{2}{*}{ Year05 } & -0.0298 & 0.386 & 0.00376 \\
\hline & $(-0.11)$ & $(0.80)$ & $(0.01)$ \\
\hline \multirow[t]{2}{*}{$E G Y$} & 0.0709 & $-1.301^{*}$ & $1.363^{* * *}$ \\
\hline & $(0.16)$ & $(-1.68)$ & $(4.62)$ \\
\hline \multirow[t]{2}{*}{$G M B$} & $-0.961^{* * *}$ & -0.687 & 0.0465 \\
\hline & $(-2.63)$ & $(-1.53)$ & $(0.21)$ \\
\hline \multirow[t]{2}{*}{$M L I$} & $-1.145^{* * *}$ & dropped & 0.396 \\
\hline & $(-3.09)$ & & (1.52) \\
\hline \multirow[t]{2}{*}{$N G A$} & -0.324 & -0.450 & $0.844^{* * *}$ \\
\hline & $(-1.13)$ & $(-1.12)$ & $(3.62)$ \\
\hline \multirow[t]{2}{*}{$S D N$} & $-1.919^{* * *}$ & $-0.973^{*}$ & $0.614^{* * * *}$ \\
\hline & $(-4.79)$ & $(-1.95)$ & $(2.88)$ \\
\hline \multirow[t]{2}{*}{ SEN } & $-0.689^{* *}$ & 0.281 & $0.746^{* * *}$ \\
\hline & $(-2.12)$ & $(0.53)$ & $(3.42)$ \\
\hline \multirow[t]{2}{*}{$T C D$} & dropped & $-0.877^{*}$ & dropped \\
\hline & & $(-1.67)$ & \\
\hline \multirow[t]{2}{*}{$Z W E$} & $-1.141^{* * *}$ & dropped & $-0.529^{* * *}$ \\
\hline & $(-6.81)$ & & $(-2.63)$ \\
\hline \multirow[t]{2}{*}{$A U T$} & $1.776^{* *}$ & $2.376^{*}$ & 0.902 \\
\hline & (2.53) & (1.84) & $(0.76)$ \\
\hline \multirow[t]{2}{*}{$B L X$} & $1.292^{* *}$ & $2.074^{* * *}$ & 0.578 \\
\hline & $(2.21)$ & (2.93) & $(0.56)$ \\
\hline \multirow[t]{2}{*}{$C H E$} & 0.621 & $1.946^{*}$ & 0.189 \\
\hline & (1.32) & (1.85) & $(0.25)$ \\
\hline \multirow[t]{2}{*}{$D E U$} & -0.358 & -0.552 & 0.153 \\
\hline & $(-1.31)$ & $(-0.84)$ & $(0.52)$ \\
\hline$D N K$ & $-1.865^{* * *}$ & -0.770 & $-1.810^{* * *}$ \\
\hline
\end{tabular}




\begin{tabular}{lccc} 
& $(-5.32)$ & $(-1.19)$ & $(-6.08)$ \\
ESP & $1.205^{* * *}$ & $-1.971^{* * *}$ & -0.0897 \\
$F I N$ & $(3.52)$ & $(-3.48)$ & $(-0.16)$ \\
& $1.418^{*}$ & dropped & 0.865 \\
$G B R$ & $(1.67)$ & & $(0.59)$ \\
& 0.121 & 0.363 & 0.470 \\
$I R L$ & $(0.43)$ & $(0.55)$ & $(1.55)$ \\
& $2.546^{* * *}$ & dropped & 1.228 \\
$I T A$ & $(2.71)$ & & $(0.73)$ \\
& 0.375 & 0.137 & $-0.442^{*}$ \\
$N L D$ & $(1.40)$ & $(0.55)$ & $(-1.70)$ \\
& $1.479^{* * *}$ & $1.314^{* *}$ & $1.676^{* *}$ \\
PRT & $(3.21)$ & $(2.37)$ & $(2.12)$ \\
& dropped & -1.302 & 1.090 \\
SWE & & $(-0.83)$ & $(0.72)$ \\
& $-2.247^{* * *}$ & $-2.240^{* * *}$ & $-2.985^{* * *}$ \\
Cons & $(-5.86)$ & $(-3.64)$ & $(-5.48)$ \\
& $-44.02^{* * *}$ & $-36.76^{* * *}$ & $-35.34^{* *}$ \\
\hline Obs & $(-4.17)$ & $(-2.86)$ & $(-2.05)$ \\
\hline
\end{tabular}

Notes: $z$ statistics in parentheses; ${ }^{*} p<0.10,{ }^{* *} p<0.05,{ }^{* * *} p<0.01$; some country dummies are dropped because they don't export or import at all for a particular groundnut product.

Table A1-5: Second-stage of HMR (Nonlinear Least Square) models (sectoral)

\begin{tabular}{lccc}
\hline NLS & $($ edible $)$ & (oil) & (shelled) \\
In_Trade \\
MRL & ln_Trade & In_Trade & 0.0314 \\
GDP & -0.408 & 1.006 & $(0.09)$ \\
& $(-1.10)$ & $(0.68)$ & 0.0891 \\
Supply & $-7.150^{* * *}$ & -4.007 & $(0.05)$ \\
& $(-3.29)$ & $(-1.02)$ & 0.276 \\
Dist & $0.441^{* * *}$ & $0.836^{*}$ & $(1.54)$ \\
Dlang & $(3.35)$ & $(1.78)$ & -1.403 \\
& -0.395 & $-7.372^{* *}$ & $(-1.06)$ \\
Year89 & $(-0.20)$ & $(-2.01)$ & -1.399 \\
& 1.082 & 0.360 & $(-3.11)$ \\
Year90 & $(1.09)$ & $(1.04)$ & -0.0490 \\
& -0.202 & -1.869 & $(-0.05)$ \\
Year91 & $(-0.17)$ & $(-0.60)$ & 0.772 \\
& $-1.844^{*}$ & -2.020 & $(0.77)$ \\
Year92 & $(-1.81)$ & $(-0.80)$ & 0.591 \\
Year93 & -1.610 & -1.597 & $(0.60)$ \\
& $(-1.55)$ & $(-0.77)$ & -0.236 \\
Year94 & -0.964 & -1.579 & $(-0.24)$ \\
& $(-1.00)$ & $(-0.72)$ & 0.244 \\
& -0.919 & -1.976 & $(0.25)$ \\
& $(-0.98)$ & $(-1.05)$ & 0.451
\end{tabular}




\begin{tabular}{|c|c|c|c|}
\hline & $(-1.44)$ & $(-0.46)$ & $(0.48)$ \\
\hline \multirow[t]{2}{*}{ Year95 } & -0.246 & -1.210 & 0.404 \\
\hline & $(-0.31)$ & $(-0.44)$ & $(0.45)$ \\
\hline \multirow[t]{2}{*}{ Year96 } & -0.563 & -1.147 & -0.202 \\
\hline & $(-0.58)$ & $(-0.76)$ & $(-0.24)$ \\
\hline \multirow[t]{2}{*}{ Year97 } & $-1.295^{*}$ & -1.185 & -0.100 \\
\hline & $(-1.72)$ & $(-0.54)$ & $(-0.13)$ \\
\hline \multirow[t]{2}{*}{ Year98 } & -0.864 & -0.960 & -0.231 \\
\hline & $(-1.13)$ & $(-0.51)$ & $(-0.31)$ \\
\hline \multirow[t]{2}{*}{ Year99 } & -0.689 & -0.809 & -0.229 \\
\hline & $(-1.04)$ & $(-0.73)$ & $(-0.30)$ \\
\hline \multirow[t]{2}{*}{ Year00 } & -0.507 & -1.046 & -0.391 \\
\hline & $(-0.84)$ & $(-0.70)$ & $(-0.56)$ \\
\hline \multirow[t]{2}{*}{ Year01 } & -0.568 & -0.785 & -0.352 \\
\hline & $(-0.94)$ & $(-0.41)$ & $(-0.52)$ \\
\hline \multirow[t]{2}{*}{ Year02 } & -0.234 & -0.423 & 0.0308 \\
\hline & $(-0.39)$ & $(-0.21)$ & $(0.05)$ \\
\hline \multirow[t]{2}{*}{ Year03 } & -0.0636 & -0.569 & -0.849 \\
\hline & $(-0.11)$ & $(-0.40)$ & $(-1.43)$ \\
\hline \multirow[t]{2}{*}{ Year04 } & -0.0735 & -1.204 & -0.0976 \\
\hline & $(-0.13)$ & $(-0.70)$ & $(-0.17)$ \\
\hline \multirow[t]{2}{*}{ Year05 } & 0.0773 & -0.0771 & 0.219 \\
\hline & $(0.14)$ & $(-0.08)$ & $(0.38)$ \\
\hline \multirow[t]{2}{*}{$E G Y$} & -0.0653 & $-9.331^{* *}$ & $-3.217^{* *}$ \\
\hline & $(-0.03)$ & $(-2.38)$ & $(-2.11)$ \\
\hline \multirow[t]{2}{*}{$G M B$} & 1.597 & $-4.785^{* *}$ & -0.970 \\
\hline & $(0.89)$ & $(-2.17)$ & $(-0.92)$ \\
\hline \multirow[t]{2}{*}{$M L I$} & -0.498 & dropped & -0.425 \\
\hline & $(-0.26)$ & & $(-0.31)$ \\
\hline \multirow[t]{2}{*}{$N G A$} & -1.324 & $-4.205^{* *}$ & $-2.787^{* *}$ \\
\hline & $(-1.07)$ & $(-2.27)$ & $(-2.45)$ \\
\hline \multirow[t]{2}{*}{$S D N$} & 2.209 & $-5.762^{* *}$ & -1.400 \\
\hline & (0.93) & $(-2.19)$ & $(-1.35)$ \\
\hline \multirow[t]{2}{*}{ SEN } & 0.760 & $-6.067^{* * *}$ & -1.525 \\
\hline & $(0.46)$ & $(-3.80)$ & $(-1.36)$ \\
\hline \multirow[t]{2}{*}{$T C D$} & dropped & $-6.189^{* *}$ & dropped \\
\hline & & $(-2.26)$ & \\
\hline \multirow[t]{2}{*}{$Z W E$} & 0.527 & dropped & $-1.665^{* *}$ \\
\hline & $(0.48)$ & & $(-2.40)$ \\
\hline \multirow[t]{2}{*}{$A U T$} & $-15.61^{* * *}$ & -10.63 & -2.170 \\
\hline & $(-3.81)$ & $(-1.45)$ & $(-0.57)$ \\
\hline \multirow[t]{2}{*}{$B L X$} & $-10.42^{* * *}$ & -8.277 & -0.226 \\
\hline & $(-3.08)$ & $(-1.40)$ & $(-0.07)$ \\
\hline \multirow[t]{2}{*}{ CHE } & $-10.10^{* * *}$ & -6.133 & 2.570 \\
\hline & $(-4.04)$ & $(-1.23)$ & (1.08) \\
\hline$D E U$ & $3.730^{* * *}$ & 1.503 & 0.437 \\
\hline
\end{tabular}




\begin{tabular}{|c|c|c|c|}
\hline & (3.91) & $(0.93)$ & $(0.51)$ \\
\hline \multirow[t]{2}{*}{$D N K$} & $-5.330^{* *}$ & $-3.148^{*}$ & -0.563 \\
\hline & $(-2.49)$ & $(-1.84)$ & $(-0.36)$ \\
\hline \multirow[t]{2}{*}{$E S P$} & $-5.217^{* * *}$ & $-12.60^{* * *}$ & -0.00257 \\
\hline & $(-2.79)$ & $(-2.73)$ & $(-0.00)$ \\
\hline \multirow[t]{2}{*}{ FIN } & $-19.90^{* * * *}$ & dropped & 0.313 \\
\hline & $(-4.11)$ & & $(0.07)$ \\
\hline \multirow[t]{2}{*}{$G B R$} & $-2.851^{* *}$ & -1.947 & $1.756^{*}$ \\
\hline & $(-2.23)$ & $(-1.14)$ & (1.93) \\
\hline \multirow[t]{2}{*}{$I R L$} & $-21.45^{* * *}$ & dropped & -1.668 \\
\hline & $(-3.95)$ & & $(-0.32)$ \\
\hline \multirow[t]{2}{*}{$I T A$} & -0.174 & -0.856 & $2.133^{* *}$ \\
\hline & $(-0.23)$ & $(-1.25)$ & $(2.41)$ \\
\hline \multirow[t]{2}{*}{$N L D$} & $-8.340^{* * *}$ & -7.349 & 0.767 \\
\hline & $(-2.91)$ & $(-1.64)$ & $(0.30)$ \\
\hline \multirow[t]{2}{*}{$P R T$} & dropped & $-19.73^{* *}$ & -0.741 \\
\hline & & $(-2.31)$ & $(-0.15)$ \\
\hline \multirow[t]{2}{*}{ SWE } & 0.873 & -0.424 & -1.483 \\
\hline & (0.39) & $(-0.11)$ & $(-0.58)$ \\
\hline \multirow[t]{2}{*}{ Delta $^{a}$} & $2.958^{* * *}$ & 0.785 & 0.768 \\
\hline & $(3.50)$ & (0.37) & $(1.21)$ \\
\hline \multirow[t]{2}{*}{$I M R$} & 0.764 & 0.590 & 0.136 \\
\hline & $(0.75)$ & $(0.31)$ & $(0.23)$ \\
\hline \multirow[t]{2}{*}{ Cons } & $197.1^{* * *}$ & $172.5^{*}$ & 11.46 \\
\hline & (2.94) & (1.67) & $(0.20)$ \\
\hline Obs & 287 & 231 & 462 \\
\hline
\end{tabular}

Notes: a. Delta is the parameter in the non-linear term accounting for the newly entered firms' effect. $t$ statistics in parentheses; ${ }^{*} p<0.10,{ }^{* *} p<0.05,{ }^{* * *} p<0.01$; some country dummies are dropped because they don't export or import at all for a particular groundnut product.

Table A1-6: PPML models (sectoral)

\begin{tabular}{lccc}
\hline PPML & (edible) & (oil) & (shelled) \\
Trade & Trade & Trade \\
MRL & $-0.435^{*}$ & $2.997^{* * *}$ & -0.340 \\
& $(-1.91)$ & $(3.21)$ & $(-1.29)$ \\
GDP & $2.637^{*}$ & $2.262^{* * *}$ & $7.463^{* * *}$ \\
& $(1.81)$ & $(14.37)$ & $(2.85)$ \\
Supply & $0.407^{* * *}$ & $1.082^{* * *}$ & $1.134^{* * *}$ \\
& $(4.67)$ & $(14.46)$ & $(9.17)^{* * *}$ \\
Dist & $2.356^{*}$ & $-8.132^{* * *}$ & $-2.497^{* * *}$ \\
& $(1.91)$ & $(-10.55)$ & $(-3.88)$ \\
Dlang & -1.134 & 0.0476 & -0.521 \\
& $(-1.55)$ & $(0.11)$ & $(-1.46)$ \\
Dcol & $1.274^{* * *}$ & -0.0670 & $1.229^{* * *}$ \\
& $(2.72)$ & $(-0.16)$ & $(4.94)$ \\
Year89 & 0.544 & $1.007^{* *}$ & $2.626^{* *}$ \\
& $(0.73)$ & $(2.21)$ & $(2.16)$
\end{tabular}




\begin{tabular}{|c|c|c|c|}
\hline Year 90 & $\begin{array}{l}-0.143 \\
(-0.20)\end{array}$ & $\begin{array}{c}0.913^{* *} \\
(2.08)\end{array}$ & $\begin{array}{l}2.323^{*} \\
(1.94)\end{array}$ \\
\hline Year91 & -0.0432 & $0.888^{* *}$ & $2.460^{* *}$ \\
\hline & $(-0.05)$ & $(2.06)$ & $(2.28)$ \\
\hline Year92 & -0.214 & $0.901^{* * *}$ & $1.767^{*}$ \\
\hline Year93 & 0.0262 & $\begin{array}{l}0.915^{* *} \\
(2.12)\end{array}$ & $\begin{array}{l}1.567 \\
(1.55)\end{array}$ \\
\hline Year94 & $\begin{array}{l}-0.139 \\
(-0.23)\end{array}$ & $\begin{array}{l}0.854^{*} \\
(1.88)\end{array}$ & $\begin{array}{l}(1.55) \\
1.690^{*} \\
(1.70)\end{array}$ \\
\hline Year95 & $\begin{array}{l}0.513 \\
(0.90)\end{array}$ & $\begin{array}{l}0.808^{*} \\
(1.89)\end{array}$ & $\begin{array}{l}1.538^{*} \\
(1.67)\end{array}$ \\
\hline Year96 & $\begin{array}{c}-0.0319 \\
(-0.06)\end{array}$ & $\begin{array}{l}0.775^{*} \\
(1.77)\end{array}$ & $\begin{array}{l}1.425 \\
(1.63)\end{array}$ \\
\hline Year97 & $\begin{array}{c}-0.0829 \\
(-0.16)\end{array}$ & $\begin{array}{l}0.687 \\
(1.52)\end{array}$ & $\begin{array}{l}1.345^{*} \\
(1.70)\end{array}$ \\
\hline Year98 & $\begin{array}{l}-0.260 \\
(-0.69)\end{array}$ & $\begin{array}{l}0.559 \\
(1.22)\end{array}$ & $\begin{array}{l}0.730 \\
(0.91)\end{array}$ \\
\hline Year99 & $\begin{array}{c}-0.0329 \\
(-0.10)\end{array}$ & $\begin{array}{l}0.547 \\
(1.18)\end{array}$ & $\begin{array}{l}0.540 \\
(0.83)\end{array}$ \\
\hline Year00 & $\begin{array}{l}-0.230 \\
(-0.72)\end{array}$ & $\begin{array}{l}0.503 \\
(1.15)\end{array}$ & $\begin{array}{l}0.180 \\
(0.27)\end{array}$ \\
\hline Year01 & $\begin{array}{l}-0.167 \\
(-0.44)\end{array}$ & $\begin{array}{l}0.364 \\
(0.77)\end{array}$ & $\begin{array}{l}0.513 \\
(0.86)\end{array}$ \\
\hline Year02 & $\begin{array}{l}-0.353 \\
(-1.10)\end{array}$ & $\begin{array}{l}0.427 \\
(0.94)\end{array}$ & $\begin{array}{l}0.706 \\
(1.40)\end{array}$ \\
\hline Year03 & $\begin{array}{l}-0.131 \\
(-0.50)\end{array}$ & $\begin{array}{l}0.434 \\
(0.96)\end{array}$ & $\begin{array}{l}0.616 \\
(1.20)\end{array}$ \\
\hline Year04 & $\begin{array}{l}-0.193 \\
(-0.67)\end{array}$ & $\begin{array}{l}0.425 \\
(1.00)\end{array}$ & $\begin{array}{l}0.370 \\
(0.62)\end{array}$ \\
\hline Year05 & $\begin{array}{c}0.0412 \\
(0.17)\end{array}$ & $\begin{array}{l}0.382 \\
(0.89)\end{array}$ & $\begin{array}{l}0.280 \\
(0.53)\end{array}$ \\
\hline$E G Y$ & $\begin{array}{l}0.225 \\
(0.18)\end{array}$ & $\begin{array}{c}-11.52^{* * *} \\
(-8.23)\end{array}$ & $\begin{array}{c}-2.598^{* * *} \\
(-4.45)\end{array}$ \\
\hline$G M B$ & $\begin{array}{l}0.985 \\
(0.90)\end{array}$ & $\begin{array}{c}-3.735^{* * *} \\
(-5.85)\end{array}$ & $\begin{array}{c}-1.172^{* * *} \\
(-2.74)\end{array}$ \\
\hline$M L I$ & $\begin{array}{c}-3.009^{3 * *} \\
(-2.76)\end{array}$ & dropped & $\begin{array}{c}-2.699^{* * * *} \\
(-6.21)\end{array}$ \\
\hline$N G A$ & $\begin{array}{l}-0.858 \\
(-0.98)\end{array}$ & $\begin{array}{c}-3.520^{* * *} \\
(-5.49)\end{array}$ & $\begin{array}{c}-0.954^{* *} \\
(-2.12)\end{array}$ \\
\hline$S D N$ & $\begin{array}{l}-2.518^{* * *} \\
(-2.29)\end{array}$ & $\begin{array}{c}-4.498^{* * *} \\
(-6.61)\end{array}$ & $\begin{array}{c}-0.963^{* *} \\
(-2.32)\end{array}$ \\
\hline SEN & $\begin{array}{l}-0.396 \\
(-0.42)\end{array}$ & $\begin{array}{c}-4.085^{* * *} \\
(-6.07)\end{array}$ & $\begin{array}{l}-0.488 \\
(-1.24)\end{array}$ \\
\hline$T C D$ & dropped & $\begin{array}{c}-4.724^{* * *} \\
(-7.59)\end{array}$ & dropped \\
\hline
\end{tabular}




\begin{tabular}{|c|c|c|c|}
\hline$Z W E$ & $\begin{array}{c}-1.914^{* * *} \\
(-6.38)\end{array}$ & dropped & $\begin{array}{c}-1.549^{* * *} \\
(-3.00)\end{array}$ \\
\hline \multirow[t]{2}{*}{$A U T$} & 2.580 & 2.522 & $11.19^{* *}$ \\
\hline & $(0.91)$ & $(1.40)$ & (2.17) \\
\hline \multirow[t]{2}{*}{$B L X$} & $5.074^{* *}$ & $1.820^{* * *}$ & $10.93^{* *}$ \\
\hline & $(2.14)$ & (4.09) & $(2.49)$ \\
\hline \multirow[t]{2}{*}{ CHE } & 0.627 & $3.255^{* *}$ & $9.506^{* * *}$ \\
\hline & $(0.35)$ & $(2.52)$ & (2.87) \\
\hline \multirow[t]{2}{*}{$D E U$} & 0.272 & 0.251 & -1.553 \\
\hline & $(0.44)$ & $(0.28)$ & $(-1.47)$ \\
\hline \multirow[t]{2}{*}{ DNK } & $-6.243^{* * *}$ & $-2.440^{* *}$ & $-4.516^{* * *}$ \\
\hline & $(-5.85)$ & $(-2.42)$ & $(-4.82)$ \\
\hline \multirow[t]{2}{*}{$E S P$} & $3.772^{* * *}$ & $-10.08^{* * *}$ & 2.956 \\
\hline & (3.43) & $(-12.04)$ & (1.31) \\
\hline \multirow[t]{2}{*}{ FIN } & 3.001 & dropped & $16.97^{* * *}$ \\
\hline & $(0.85)$ & & $(2.71)$ \\
\hline \multirow[t]{2}{*}{$G B R$} & $2.399^{* * * *}$ & 1.037 & $4.055^{* * *}$ \\
\hline & $(2.85)$ & (1.14) & (3.67) \\
\hline \multirow[t]{2}{*}{$I R L$} & 5.175 & dropped & $15.89^{* *}$ \\
\hline & $(1.44)$ & & $(2.40)$ \\
\hline \multirow[t]{2}{*}{$I T A$} & $1.280^{* * * *}$ & -0.300 & $1.626^{* *}$ \\
\hline & (3.48) & $(-1.29)$ & $(2.40)$ \\
\hline \multirow[t]{2}{*}{$N L D$} & $4.236^{* *}$ & 0.406 & $11.15^{* * *}$ \\
\hline & $(2.33)$ & (1.29) & (3.28) \\
\hline \multirow[t]{2}{*}{$P R T$} & dropped & $-11.41^{* * *}$ & $17.23^{* * *}$ \\
\hline & & $(-6.18)$ & (2.67) \\
\hline \multirow[t]{2}{*}{$S W E$} & $-5.492^{* * *}$ & $-4.504^{* * *}$ & $-11.16^{* * *}$ \\
\hline & $(-5.54)$ & $(-5.44)$ & $(-6.94)$ \\
\hline \multirow[t]{2}{*}{ Cons } & $-97.41^{* *}$ & -5.703 & $-199.7^{* * *}$ \\
\hline & $(-2.35)$ & $(-0.78)$ & $(-2.67)$ \\
\hline Obs & 1736 & 1470 & 2156 \\
\hline
\end{tabular}

Notes: $z$ statistics in parentheses; ${ }^{*} p<0.10,{ }^{* *} p<0.05,{ }^{* * *} p<0.01$; some country dummies are dropped because they don't export or import at all for a particular groundnut product.

Table A1-7: NBPML models (sectoral)

\begin{tabular}{lccc}
\hline NBPML & (edible) & (oil) & (shelled) \\
& Trade & Trade & Trade \\
MRL & $-0.716^{* *}$ & 1.560 & $1.330^{* * *}$ \\
& $(-2.29)$ & $(1.24)$ & $(5.03)$ \\
GDP & $2.286^{* * *}$ & $6.016^{* * *}$ & $2.685^{*}$ \\
& $(6.70)$ & $(21.86)$ & $(1.65)$ \\
Supply & $0.252^{* * *}$ & $1.437^{* * *}$ & $1.338^{* * *}$ \\
& $(3.55)$ & $(14.53)$ & $(15.18)$ \\
Dist & $3.439^{* * *}$ & $-3.949^{* * *}$ & $3.104^{* * *}$ \\
& $(3.28)$ & $(-3.44)$ & $(4.07)$ \\
Dlang & -0.472 & -0.986 & 0.0539 \\
& $(-0.91)$ & $(-1.62)$ & $(0.12)$
\end{tabular}




\begin{tabular}{|c|c|c|c|}
\hline Dcol & $\begin{array}{c}1.986^{* * *} \\
(3.75)\end{array}$ & $\begin{array}{l}1.433^{* *} \\
(2.15)\end{array}$ & $\begin{array}{c}1.776^{* * *} \\
(3.34)\end{array}$ \\
\hline Year89 & $\begin{array}{c}2.484^{* * *} \\
(3.67)\end{array}$ & $\begin{array}{c}5.083^{* * *} \\
(6.07)\end{array}$ & $\begin{array}{c}4.054^{* * *} \\
(4.49)\end{array}$ \\
\hline Year90 & $\begin{array}{l}0.611 \\
(1.06)\end{array}$ & $\begin{array}{c}3.355^{* * * *} \\
(5.28)\end{array}$ & $\begin{array}{c}3.592^{* * *} \\
(4.43)\end{array}$ \\
\hline Year91 & $\begin{array}{c}2.060^{* * *} \\
(2.60)\end{array}$ & $\begin{array}{c}3.221^{* * *} \\
(4.67)\end{array}$ & $\begin{array}{c}3.522^{* * *} \\
(4.14)\end{array}$ \\
\hline Year92 & $\begin{array}{l}0.897 \\
(1.61)\end{array}$ & $\begin{array}{c}4.320^{* * *} \\
(4.31)\end{array}$ & $\begin{array}{c}2.117^{* *} \\
(2.45)\end{array}$ \\
\hline Year93 & $\begin{array}{l}0.891 \\
(1.55)\end{array}$ & $\begin{array}{c}3.276^{* * *} \\
(3.93)\end{array}$ & $\begin{array}{c}0.604 \\
(0.78)\end{array}$ \\
\hline Year94 & $\begin{array}{l}0.924^{*} \\
(1.83)\end{array}$ & $\begin{array}{c}3.893^{* * *} \\
(5.63)\end{array}$ & $\begin{array}{c}2.980^{* * * *} \\
(3.72)\end{array}$ \\
\hline Year95 & $\begin{array}{l}1.077^{* *} \\
(2.16)\end{array}$ & $\begin{array}{c}4.077^{* * *} \\
(6.09)\end{array}$ & $\begin{array}{c}1.925^{* * *} \\
(2.70)\end{array}$ \\
\hline Year96 & $\begin{array}{l}-0.803 \\
(-1.59)\end{array}$ & $\begin{array}{c}2.287^{* * * *} \\
(3.38)\end{array}$ & $\begin{array}{c}1.739^{* *} \\
(2.58)\end{array}$ \\
\hline Year97 & $\begin{array}{c}0.0343 \\
(0.07)\end{array}$ & $\begin{array}{c}2.586^{* * *} \\
(4.23)\end{array}$ & $\begin{array}{c}2.020^{* * * *} \\
(3.10)\end{array}$ \\
\hline Year98 & $\begin{array}{l}-0.775^{*} \\
(-1.67)\end{array}$ & $\begin{array}{c}2.356^{* * *} \\
(3.55)\end{array}$ & $\begin{array}{c}3.150^{* * *} \\
(3.91)\end{array}$ \\
\hline Year99 & $\begin{array}{l}1.003^{* *} \\
(2.13)\end{array}$ & $\begin{array}{c}2.055^{* *} \\
(2.54)\end{array}$ & $\begin{array}{c}2.829^{* * * *} \\
(4.30)\end{array}$ \\
\hline Year00 & $\begin{array}{l}0.803 \\
(1.64)\end{array}$ & $\begin{array}{l}1.082^{*} \\
(1.74)\end{array}$ & $\begin{array}{c}2.380^{* * *} \\
(3.75)\end{array}$ \\
\hline Year01 & $\begin{array}{l}0.923 \\
(1.59)\end{array}$ & $\begin{array}{c}1.819^{* * *} \\
(2.84)\end{array}$ & $\begin{array}{c}2.046^{* * * *} \\
(3.52)\end{array}$ \\
\hline Year02 & $\begin{array}{l}0.657 \\
(1.05)\end{array}$ & $\begin{array}{c}2.113^{* * *} \\
(3.44)\end{array}$ & $\begin{array}{l}-0.153 \\
(-0.32)\end{array}$ \\
\hline Year03 & $\begin{array}{l}0.404 \\
(0.90)\end{array}$ & $\begin{array}{c}2.605^{* * *} \\
(3.45)\end{array}$ & $\begin{array}{l}0.571 \\
(1.25)\end{array}$ \\
\hline Year04 & $\begin{array}{l}1.119^{* *} \\
(2.13)\end{array}$ & $\begin{array}{l}0.931 \\
(1.61)\end{array}$ & $\begin{array}{l}0.510 \\
(1.18)\end{array}$ \\
\hline Year05 & $\begin{array}{l}0.138 \\
(0.33)\end{array}$ & $\begin{array}{l}1.558^{*} \\
(1.77)\end{array}$ & $\begin{array}{c}0.199 \\
(0.43)\end{array}$ \\
\hline$E G Y$ & $\begin{array}{l}1.815 \\
(1.50)\end{array}$ & $\begin{array}{l}-2.891^{*} \\
(-1.94)\end{array}$ & $\begin{array}{c}4.882^{* * *} \\
(6.62)\end{array}$ \\
\hline$G M B$ & $\begin{array}{l}-1.027 \\
(-1.09)\end{array}$ & $\begin{array}{l}-1.697^{*} \\
(-1.94)\end{array}$ & $\begin{array}{c}1.660^{* * *} \\
(2.85)\end{array}$ \\
\hline$M L I$ & $\begin{array}{c}-3.160^{* * *} \\
(-3.32)\end{array}$ & dropped & $\begin{array}{l}1.136^{*} \\
(1.65)\end{array}$ \\
\hline$N G A$ & $\begin{array}{l}-0.186 \\
(-0.25)\end{array}$ & $\begin{array}{l}-1.252 \\
(-1.35)\end{array}$ & $\begin{array}{c}3.590^{* * *} \\
(5.83)\end{array}$ \\
\hline$S D N$ & $\begin{array}{c}-3.732^{* * *} \\
(-4.46)\end{array}$ & $\begin{array}{c}-3.036^{* * *} \\
(-3.11)\end{array}$ & $\begin{array}{c}2.252^{* * *} \\
(3.99)\end{array}$ \\
\hline
\end{tabular}




\begin{tabular}{|c|c|c|c|}
\hline SEN & $\begin{array}{l}-0.688 \\
(-0.82)\end{array}$ & $\begin{array}{c}-1.841^{*} \\
(-1.70)\end{array}$ & $\begin{array}{c}2.904^{* * *} \\
(4.87)\end{array}$ \\
\hline$T C D$ & dropped & $\begin{array}{c}-3.105^{* * *} \\
(-3.17)\end{array}$ & dropped \\
\hline$Z W E$ & $\begin{array}{c}-2.564^{* * *} \\
(-6.25)\end{array}$ & dropped & $\begin{array}{c}-2.290^{* * *} \\
(-4.10)\end{array}$ \\
\hline$A U T$ & $\begin{array}{c}1.747^{* * *} \\
(2.76)\end{array}$ & $\begin{array}{c}7.295^{* * *} \\
(3.76)\end{array}$ & $\begin{array}{l}-1.107 \\
(-0.35)\end{array}$ \\
\hline$B L X$ & $\begin{array}{c}3.400^{* * *} \\
(7.30)\end{array}$ & $\begin{array}{l}8.861^{* * *} \\
(11.57)\end{array}$ & $\begin{array}{l}-2.297 \\
(-0.84)\end{array}$ \\
\hline CHE & $\begin{array}{c}-0.0499 \\
(-0.08)\end{array}$ & $\begin{array}{c}7.043^{* * *} \\
(4.14)\end{array}$ & $\begin{array}{l}1.592 \\
(0.80)\end{array}$ \\
\hline$D E U$ & $\begin{array}{l}-0.489 \\
(-0.91)\end{array}$ & $\begin{array}{c}-2.982^{* *} \\
(-2.24)\end{array}$ & $\begin{array}{c}-3.039^{* * *} \\
(-3.70)\end{array}$ \\
\hline$D N K$ & $\begin{array}{c}-6.499^{* * *} \\
(-4.32)\end{array}$ & $\begin{array}{c}-4.755^{* * *} \\
(-3.78)\end{array}$ & $\begin{array}{c}-7.297^{* * *} \\
(-8.86)\end{array}$ \\
\hline$E S P$ & $\begin{array}{c}2.531^{* * *} \\
(5.73)\end{array}$ & $\begin{array}{c}-6.820^{* * * *} \\
(-9.99)\end{array}$ & $\begin{array}{l}-2.953^{*} \\
(-1.94)\end{array}$ \\
\hline FIN & $\begin{array}{c}0.786 \\
(0.97)\end{array}$ & dropped & $\begin{array}{l}0.251 \\
(0.06)\end{array}$ \\
\hline$G B R$ & $\begin{array}{l}1.029^{*} \\
(1.84)\end{array}$ & $\begin{array}{l}1.453 \\
(1.21)\end{array}$ & $\begin{array}{c}-0.0741 \\
(-0.09)\end{array}$ \\
\hline IRL & $\begin{array}{c}4.576^{* * *} \\
(6.03)\end{array}$ & dropped & $\begin{array}{l}-0.482 \\
(-0.11)\end{array}$ \\
\hline$I T A$ & $\begin{array}{c}1.643^{* * * *} \\
(2.65)\end{array}$ & $\begin{array}{c}1.563^{* * *} \\
(3.62)\end{array}$ & $\begin{array}{c}-2.983^{* * *} \\
(-3.72)\end{array}$ \\
\hline$N L D$ & $\begin{array}{c}3.563^{* * * *} \\
(7.76)\end{array}$ & $\begin{array}{c}3.818^{* * *} \\
(8.55)\end{array}$ & $\begin{array}{l}1.515 \\
(0.72)\end{array}$ \\
\hline$P R T$ & dropped & $\begin{array}{c}0.684 \\
(0.27)\end{array}$ & $\begin{array}{l}-2.258 \\
(-0.56)\end{array}$ \\
\hline$S W E$ & $\begin{array}{c}-6.524^{* * *} \\
(-8.62)\end{array}$ & $\begin{array}{c}-9.753^{* * *} \\
(-8.64)\end{array}$ & $\begin{array}{l}-14.43^{* * *} \\
(-12.83)\end{array}$ \\
\hline Cons & $\begin{array}{c}-95.06^{* * *} \\
(-7.49)\end{array}$ & $\begin{array}{l}-153.2^{* * * *} \\
(-11.75)\end{array}$ & $\begin{array}{c}-120.0^{* * *} \\
(-2.61)\end{array}$ \\
\hline ln_dispersion & $\begin{array}{l}2.219^{* * *} \\
(27.85)\end{array}$ & $\begin{array}{l}2.715^{* * *} \\
(33.13)\end{array}$ & $\begin{array}{l}2.796^{* * *} \\
(52.96)\end{array}$ \\
\hline Obs & 1736 & 1470 & 2156 \\
\hline
\end{tabular}

Notes: $z$ statistics in parentheses; ${ }^{*} p<0.10,{ }^{* *} p<0.05,{ }^{* * *} p<0.01$; some country dummies are dropped because they don't export or import at all for a particular groundnut product.

Table A1-8: ZIPPML models (sectoral)

\begin{tabular}{lccc}
\hline ZIPPML & (edible) & (oil) & (shelled) \\
\hline Inflation Eq. $^{\text {a }}$ & & & \\
& Prob. of no-trade & Prob. of no-trade & Prob. of no-trade \\
MRL & 0.260 & -0.759 & 0.00721 \\
& $(1.44)$ & $(-1.44)$ & $(0.06)$ \\
GDP & 0.729 & $-1.602^{* * *}$ & 0.000849
\end{tabular}




\begin{tabular}{|c|c|c|c|}
\hline & $(0.34)$ & $(-13.27)$ & $(0.00)$ \\
\hline \multirow[t]{2}{*}{ Supply } & -0.0290 & $-0.265^{* * *}$ & $-0.349^{* * *}$ \\
\hline & $(-0.72)$ & $(-5.11)$ & $(-7.05)$ \\
\hline \multirow[t]{2}{*}{ Dist } & $-1.611^{* * *}$ & $1.561^{* * *}$ & $-0.820^{* * *}$ \\
\hline & $(-3.58)$ & (3.10) & $(-2.73)$ \\
\hline \multirow[t]{2}{*}{ Dlang } & 0.401 & 0.0386 & -0.196 \\
\hline & (1.19) & $(0.16)$ & $(-1.17)$ \\
\hline \multirow[t]{2}{*}{ Dcol } & $-1.028^{* * *}$ & -0.279 & $-1.129^{* * *}$ \\
\hline & $(-3.50)$ & $(-1.06)$ & $(-5.15)$ \\
\hline \multirow[t]{2}{*}{ Year89 } & 1.145 & $-1.824^{* * *}$ & -0.121 \\
\hline & (1.29) & $(-4.54)$ & $(-0.25)$ \\
\hline \multirow[t]{2}{*}{ Year90 } & 0.476 & $-1.461^{* * *}$ & 0.0584 \\
\hline & $(0.55)$ & $(-3.73)$ & $(0.13)$ \\
\hline \multirow[t]{2}{*}{ Year91 } & 0.329 & $-1.132^{* * *}$ & 0.0328 \\
\hline & (0.39) & $(-2.86)$ & $(0.07)$ \\
\hline \multirow[t]{2}{*}{ Year92 } & 0.757 & $-1.217^{* * *}$ & 0.289 \\
\hline & (1.01) & $(-3.04)$ & $(0.63)$ \\
\hline \multirow[t]{2}{*}{ Year93 } & 0.614 & $-0.995^{* * *}$ & 0.343 \\
\hline & $(0.81)$ & $(-2.61)$ & $(0.76)$ \\
\hline \multirow[t]{2}{*}{ Year94 } & 0.215 & $-1.087^{* * *}$ & -0.215 \\
\hline & (0.31) & $(-2.88)$ & $(-0.52)$ \\
\hline \multirow[t]{2}{*}{ Year95 } & 0.498 & $-1.658^{* * *}$ & 0.109 \\
\hline & $(0.78)$ & $(-4.32)$ & $(0.27)$ \\
\hline \multirow[t]{2}{*}{ Year96 } & $1.070^{*}$ & $-0.786^{* *}$ & -0.213 \\
\hline & (1.66) & $(-2.09)$ & $(-0.56)$ \\
\hline \multirow[t]{2}{*}{ Year97 } & 0.249 & $-1.305^{* * *}$ & -0.146 \\
\hline & $(0.44)$ & $(-3.53)$ & $(-0.41)$ \\
\hline \multirow[t]{2}{*}{ Year98 } & 0.535 & $-1.083^{* * *}$ & -0.0256 \\
\hline & (1.04) & $(-3.00)$ & $(-0.07)$ \\
\hline \multirow[t]{2}{*}{ Year99 } & 0.0166 & -0.502 & -0.168 \\
\hline & $(0.04)$ & $(-1.23)$ & $(-0.50)$ \\
\hline \multirow[t]{2}{*}{ Year00 } & 0.144 & $-0.827^{* *}$ & 0.000787 \\
\hline & (0.38) & $(-2.26)$ & $(0.00)$ \\
\hline \multirow[t]{2}{*}{ Year01 } & 0.178 & $-1.119^{* * *}$ & -0.0147 \\
\hline & $(0.53)$ & $(-2.86)$ & $(-0.05)$ \\
\hline \multirow[t]{2}{*}{ Year02 } & 0.378 & $-1.192^{* * *}$ & 0.190 \\
\hline & (1.13) & $(-3.28)$ & $(0.75)$ \\
\hline \multirow[t]{2}{*}{ Year03 } & 0.242 & $-0.790^{*}$ & -0.280 \\
\hline & $(0.76)$ & $(-1.90)$ & $(-1.07)$ \\
\hline \multirow[t]{2}{*}{ Year04 } & -0.192 & $-1.013^{* *}$ & -0.128 \\
\hline & $(-0.67)$ & $(-2.52)$ & $(-0.51)$ \\
\hline \multirow[t]{2}{*}{ Year05 } & 0.0686 & -0.382 & 0.0248 \\
\hline & $(0.25)$ & $(-0.84)$ & $(0.10)$ \\
\hline \multirow[t]{2}{*}{$E G Y$} & -0.335 & 1.114 & $-1.542^{* * *}$ \\
\hline & $(-0.74)$ & (1.55) & $(-4.61)$ \\
\hline$G M B$ & $0.952^{* * *}$ & $0.640^{*}$ & -0.115 \\
\hline
\end{tabular}




\begin{tabular}{|c|c|c|c|}
\hline & (2.61) & (1.83) & $(-0.53)$ \\
\hline$M L I$ & $0.851^{* *}$ & dropped & $\begin{array}{c}-0.438^{* *} \\
(-2.06)\end{array}$ \\
\hline$N G A$ & $\begin{array}{c}-0.00840 \\
(-0.03)\end{array}$ & $\begin{array}{l}0.405 \\
(1.06)\end{array}$ & $\begin{array}{c}-0.883^{* * * *} \\
(-4.41)\end{array}$ \\
\hline$S D N$ & $\begin{array}{c}1.914^{* * *} \\
(4.51)\end{array}$ & $\begin{array}{l}0.914^{* *} \\
(2.15)\end{array}$ & $\begin{array}{c}-0.679^{* * *} \\
(-3.57)\end{array}$ \\
\hline SEN & $\begin{array}{l}0.540^{*} \\
(1.69)\end{array}$ & $\begin{array}{l}-0.344 \\
(-0.73)\end{array}$ & $\begin{array}{r}-0.798^{* * *} \\
(-4.43)\end{array}$ \\
\hline$T C D$ & dropped & $\begin{array}{c}0.825^{* *} \\
(2.26)\end{array}$ & dropped \\
\hline$Z W E$ & $\begin{array}{c}1.120^{* * *} \\
(6.23)\end{array}$ & dropped & $\begin{array}{c}0.579^{* * *} \\
(2.84)\end{array}$ \\
\hline$A U T$ & $\begin{array}{l}1.327 \\
(0.31)\end{array}$ & $\begin{array}{c}-2.382^{* * *} \\
(-2.80)\end{array}$ & $\begin{array}{c}0.688 \\
(0.35)\end{array}$ \\
\hline$B L X$ & $\begin{array}{l}1.780 \\
(0.50)\end{array}$ & $\begin{array}{c}-2.079^{* * *} \\
(-7.76)\end{array}$ & $\begin{array}{l}0.839 \\
(0.50)\end{array}$ \\
\hline CHE & $\begin{array}{l}1.246 \\
(0.46)\end{array}$ & $\begin{array}{c}-1.959^{* * *} \\
(-2.79)\end{array}$ & $\begin{array}{l}0.799 \\
(0.65)\end{array}$ \\
\hline$D E U$ & $\begin{array}{l}-0.313 \\
(-0.38)\end{array}$ & $\begin{array}{l}0.549 \\
(1.01)\end{array}$ & $\begin{array}{l}-0.438 \\
(-1.07)\end{array}$ \\
\hline$D N K$ & $\begin{array}{c}-2.129^{* * *} \\
(-2.65)\end{array}$ & $\begin{array}{c}0.767 \\
(1.37)\end{array}$ & $\begin{array}{c}1.933^{* * *} \\
(5.54)\end{array}$ \\
\hline$E S P$ & $\begin{array}{c}0.279 \\
(0.16)\end{array}$ & $\begin{array}{c}1.912^{* * * *} \\
(4.49)\end{array}$ & $\begin{array}{l}0.804 \\
(0.93)\end{array}$ \\
\hline FIN & $\begin{array}{l}2.619 \\
(0.51)\end{array}$ & dropped & $\begin{array}{l}1.149 \\
(0.47)\end{array}$ \\
\hline$G B R$ & $\begin{array}{l}0.630 \\
(0.73)\end{array}$ & $\begin{array}{l}-0.374 \\
(-0.74)\end{array}$ & $\begin{array}{l}-0.127 \\
(-0.28)\end{array}$ \\
\hline$I R L$ & $\begin{array}{l}1.811 \\
(0.33)\end{array}$ & dropped & $\begin{array}{c}0.773 \\
(0.30)\end{array}$ \\
\hline ITA & $\begin{array}{l}-0.178 \\
(-0.38)\end{array}$ & $\begin{array}{l}-0.144 \\
(-0.70)\end{array}$ & $\begin{array}{c}0.595^{* *} \\
(2.11)\end{array}$ \\
\hline$N L D$ & $\begin{array}{c}0.902 \\
(0.33)\end{array}$ & $\begin{array}{c}-1.325^{* * *} \\
(-5.80)\end{array}$ & $\begin{array}{l}-0.594 \\
(-0.46)\end{array}$ \\
\hline$P R T$ & dropped & $\begin{array}{l}1.257 \\
(1.12)\end{array}$ & $\begin{array}{l}0.954 \\
(0.38)\end{array}$ \\
\hline$S W E$ & $\begin{array}{l}0.837 \\
(0.74)\end{array}$ & $\begin{array}{c}2.244^{* * * *} \\
(4.49)\end{array}$ & $\begin{array}{c}2.634^{* * * *} \\
(4.29)\end{array}$ \\
\hline Cons & $\begin{array}{l}-6.486 \\
(-0.11)\end{array}$ & $\begin{array}{c}37.32^{* * *} \\
(7.35)\end{array}$ & $\begin{array}{l}13.17 \\
(0.47)\end{array}$ \\
\hline \multicolumn{4}{|c|}{ Outcome Eq. } \\
\hline$M R L$ & $\begin{array}{l}-0.354 \\
(-1.64)\end{array}$ & $\begin{array}{c}2.077^{* *} \\
(2.37)\end{array}$ & $\begin{array}{c}-0.509^{* *} \\
(-2.00)\end{array}$ \\
\hline$G D P$ & $3.058^{*}$ & -2.550 & $6.424^{* * *}$ \\
\hline
\end{tabular}




\begin{tabular}{|c|c|c|c|}
\hline & (1.80) & $(-1.39)$ & (3.34) \\
\hline \multirow[t]{2}{*}{ Supply } & $0.395^{* * *}$ & $0.847^{* * *}$ & $0.713^{* * *}$ \\
\hline & $(4.16)$ & (12.36) & $(6.86)$ \\
\hline \multirow[t]{2}{*}{ Dist } & -1.111 & $-7.018^{* * *}$ & $-8.102^{* *}$ \\
\hline & $(-0.81)$ & $(-5.49)$ & $(-2.57)$ \\
\hline \multirow[t]{2}{*}{ Dlang } & 0.122 & 0.359 & $-0.491^{* *}$ \\
\hline & $(0.26)$ & (1.27) & $(-1.96)$ \\
\hline \multirow[t]{2}{*}{ Year89 } & 1.008 & -0.434 & $1.945^{* *}$ \\
\hline & (1.23) & $(-0.65)$ & $(2.27)$ \\
\hline \multirow[t]{2}{*}{ Year90 } & 0.214 & -0.384 & $1.882^{* *}$ \\
\hline & $(0.28)$ & $(-0.62)$ & $(2.24)$ \\
\hline \multirow[t]{2}{*}{ Year91 } & 0.243 & -0.333 & $1.801^{* *}$ \\
\hline & $(0.29)$ & $(-0.56)$ & $(2.28)$ \\
\hline \multirow[t]{2}{*}{ Year92 } & 0.123 & -0.394 & $1.329^{*}$ \\
\hline & $(0.16)$ & $(-0.68)$ & $(1.74)$ \\
\hline \multirow[t]{2}{*}{ Year93 } & 0.632 & -0.401 & $1.370^{*}$ \\
\hline & $(0.88)$ & $(-0.68)$ & $(1.82)$ \\
\hline \multirow[t]{2}{*}{ Year94 } & 0.170 & -0.314 & $1.273^{*}$ \\
\hline & $(0.26)$ & $(-0.54)$ & (1.68) \\
\hline \multirow[t]{2}{*}{ Year95 } & 0.628 & -0.258 & 1.093 \\
\hline & (1.04) & $(-0.50)$ & (1.55) \\
\hline \multirow[t]{2}{*}{ Year96 } & 0.546 & -0.214 & 0.883 \\
\hline & $(0.90)$ & $(-0.42)$ & (1.31) \\
\hline \multirow[t]{2}{*}{ Year97 } & 0.0351 & -0.277 & 0.683 \\
\hline & $(0.06)$ & $(-0.54)$ & (1.09) \\
\hline \multirow[t]{2}{*}{ Year98 } & -0.185 & -0.145 & 0.416 \\
\hline & $(-0.43)$ & $(-0.30)$ & $(0.68)$ \\
\hline \multirow[t]{2}{*}{ Year99 } & 0.0136 & 0.0418 & -0.0218 \\
\hline & $(0.04)$ & $(0.09)$ & $(-0.04)$ \\
\hline \multirow[t]{2}{*}{ Year00 } & -0.205 & 0.0590 & 0.0980 \\
\hline & $(-0.60)$ & $(0.14)$ & $(0.20)$ \\
\hline \multirow[t]{2}{*}{ Year01 } & -0.0814 & 0.0607 & 0.323 \\
\hline & $(-0.19)$ & $(0.14)$ & $(0.68)$ \\
\hline \multirow[t]{2}{*}{ Year02 } & -0.268 & 0.0745 & $0.755^{*}$ \\
\hline & $(-0.75)$ & $(0.18)$ & (1.94) \\
\hline \multirow[t]{2}{*}{ Year03 } & -0.0701 & 0.102 & 0.474 \\
\hline & $(-0.23)$ & $(0.25)$ & $(1.25)$ \\
\hline \multirow[t]{2}{*}{ Year04 } & -0.253 & 0.0322 & 0.228 \\
\hline & $(-0.84)$ & $(0.09)$ & $(0.50)$ \\
\hline \multirow[t]{2}{*}{ Year05 } & 0.0304 & 0.125 & 0.328 \\
\hline & $(0.11)$ & $(0.32)$ & (0.85) \\
\hline \multirow[t]{2}{*}{$E G Y$} & -2.159 & $-9.418^{* * *}$ & $-10.37^{* * *}$ \\
\hline & $(-1.31)$ & $(-6.37)$ & $(-2.89)$ \\
\hline \multirow[t]{2}{*}{$G M B$} & 0.378 & $-4.889^{* * *}$ & $-5.893^{* * *}$ \\
\hline & $(0.36)$ & $(-4.45)$ & $(-2.60)$ \\
\hline$M L I$ & $-2.846^{* *}$ & dropped & $-6.756^{* * *}$ \\
\hline
\end{tabular}




\begin{tabular}{|c|c|c|c|}
\hline \multirow{3}{*}{$N G A$} & $(-1.97)$ & & $(-2.83)$ \\
\hline & $-2.619^{* * *}$ & $-4.429^{* * *}$ & $-5.763^{* * *}$ \\
\hline & $(-2.83)$ & $(-4.05)$ & $(-2.98)$ \\
\hline \multirow[t]{2}{*}{$S D N$} & -0.0267 & $-5.556^{* * *}$ & $-5.888^{* * *}$ \\
\hline & $(-0.03)$ & $(-4.66)$ & $(-2.68)$ \\
\hline \multirow[t]{2}{*}{ SEN } & -1.134 & $-5.192^{* * *}$ & $-6.070^{* * *}$ \\
\hline & $(-0.97)$ & $(-5.06)$ & $(-2.60)$ \\
\hline \multirow[t]{2}{*}{$T C D$} & dropped & $-6.158^{* * *}$ & dropped \\
\hline & & $(-4.96)$ & \\
\hline \multirow[t]{2}{*}{$Z W E$} & $-1.739^{* * *}$ & dropped & $-2.610^{* * *}$ \\
\hline & $(-4.55)$ & & $(-3.87)$ \\
\hline \multirow[t]{2}{*}{$A U T$} & 3.402 & -5.719 & $9.112^{* *}$ \\
\hline & (1.03) & $(-1.35)$ & $(2.49)$ \\
\hline \multirow[t]{2}{*}{$B L X$} & $5.992^{* *}$ & $-6.078^{*}$ & $9.576^{* * *}$ \\
\hline & (2.15) & $(-1.96)$ & (2.93) \\
\hline \multirow[t]{2}{*}{ CHE } & 1.184 & -3.375 & $8.552^{* * *}$ \\
\hline & $(0.56)$ & $(-1.25)$ & (3.76) \\
\hline \multirow[t]{2}{*}{$D E U$} & 0.136 & $1.595^{*}$ & $-1.565^{* *}$ \\
\hline & $(0.20)$ & (1.67) & $(-2.00)$ \\
\hline \multirow[t]{2}{*}{$D N K$} & $-6.623^{* * *}$ & $-2.696^{* * *}$ & -1.651 \\
\hline & $(-5.71)$ & $(-2.66)$ & $(-1.48)$ \\
\hline \multirow[t]{2}{*}{$E S P$} & $3.806^{* * *}$ & $-12.24^{* * *}$ & $3.341^{* * *}$ \\
\hline & (2.94) & $(-6.21)$ & (1.99) \\
\hline \multirow[t]{2}{*}{ FIN } & 4.776 & dropped & $15.34^{* * *}$ \\
\hline & (1.18) & & $(3.24)$ \\
\hline \multirow[t]{2}{*}{$G B R$} & $2.510^{* * * *}$ & -1.305 & $4.233^{* * *}$ \\
\hline & $(3.20)$ & $(-1.02)$ & $(4.83)$ \\
\hline \multirow[t]{2}{*}{$I R L$} & 5.687 & dropped & $13.41^{* * *}$ \\
\hline & $(1.40)$ & & $(2.74)$ \\
\hline \multirow[t]{2}{*}{$I T A$} & $0.979^{* *}$ & $-0.751^{*}$ & 0.852 \\
\hline & $(2.25)$ & $(-1.65)$ & $(0.87)$ \\
\hline \multirow[t]{2}{*}{$N L D$} & $5.931^{* * * *}$ & $-5.404^{* *}$ & $10.14^{* * * *}$ \\
\hline & $(2.82)$ & $(-2.21)$ & (3.99) \\
\hline \multirow[t]{2}{*}{$P R T$} & dropped & $-18.34^{* * * *}$ & $13.97^{* * *}$ \\
\hline & & $(-3.78)$ & (2.99) \\
\hline \multirow[t]{2}{*}{$S W E$} & $-4.581^{* * *}$ & -1.617 & $-5.923^{* * *}$ \\
\hline & $(-4.23)$ & $(-1.61)$ & $(-5.53)$ \\
\hline \multirow[t]{2}{*}{ Cons } & -77.30 & $126.6^{* * *}$ & $-110.6^{* *}$ \\
\hline & $(-1.58)$ & $(2.32)$ & $(-2.07)$ \\
\hline Obs & 1736 & 1470 & 2156 \\
\hline
\end{tabular}

Notes: a. The raw coefficients are reported for the inflation equations, that is, estimates should be interpreted as the effects on the probability of no-trade; $z$ statistics in parentheses; ${ }^{*} p<0.10$, ${ }^{* *} p<0.05,{ }^{* * *} p<0.01$; some country dummies are dropped because they don't export or import at all for a particular groundnut product.

Table A1-9: ZINBPML models (sectoral)

\begin{tabular}{llll}
\hline ZINBPML (edible) (oil) & (shelled)
\end{tabular}




\section{Inflation Eq. ${ }^{\text {a }}$}

\begin{tabular}{|c|c|c|c|}
\hline \multirow{3}{*}{$M R L$} & Prod. of no-trade & Prod. of no-trade & ProD. OI no-t \\
\hline & 0.324 & -0.762 & 0.0650 \\
\hline & (1.06) & $(-1.43)$ & $(0.40)$ \\
\hline \multirow[t]{2}{*}{$G D P$} & $-3.244^{* * *}$ & $-1.603^{* * *}$ & -1.235 \\
\hline & $(-4.62)$ & $(-13.26)$ & $(-1.57)$ \\
\hline \multirow[t]{2}{*}{ Supply } & $0.148^{*}$ & $-0.267^{* * *}$ & $-0.359^{* * *}$ \\
\hline & $(1.79)$ & $(-5.25)$ & $(-6.84)$ \\
\hline \multirow[t]{2}{*}{ Dist } & $2.174^{*}$ & $1.569^{* * *}$ & $-1.052^{* * *}$ \\
\hline & (1.88) & (3.15) & $(-3.02)$ \\
\hline \multirow[t]{2}{*}{ Dlang } & 0.250 & 0.0397 & $-0.475^{* *}$ \\
\hline & $(0.38)$ & $(0.17)$ & $(-2.30)$ \\
\hline \multirow[t]{2}{*}{ Dcol } & -0.851 & -0.278 & $-1.311^{* * *}$ \\
\hline & $(-1.25)$ & $(-1.06)$ & $(-4.92)$ \\
\hline \multirow[t]{2}{*}{ Year89 } & -1.190 & $-1.821^{* * *}$ & -0.570 \\
\hline & $(-1.09)$ & $(-4.54)$ & $(-1.23)$ \\
\hline \multirow[t]{2}{*}{ Year90 } & -0.902 & $-1.460^{* * *}$ & -0.345 \\
\hline & $(-1.36)$ & $(-3.72)$ & $(-0.73)$ \\
\hline \multirow[t]{2}{*}{ Year91 } & $-1.385^{*}$ & $-1.130^{* * *}$ & -0.345 \\
\hline & $(-1.88)$ & $(-2.85)$ & $(-0.74)$ \\
\hline \multirow[t]{2}{*}{ Year92 } & -0.486 & $-1.221^{* * *}$ & 0.00416 \\
\hline & $(-0.82)$ & $(-3.04)$ & $(0.01)$ \\
\hline \multirow[t]{2}{*}{ Year93 } & $-1.007^{*}$ & $-0.994^{* * *}$ & 0.119 \\
\hline & $(-1.75)$ & $(-2.60)$ & $(0.27)$ \\
\hline \multirow[t]{2}{*}{ Year94 } & $-1.091^{* *}$ & $-1.084^{* * *}$ & -0.525 \\
\hline & $(-2.38)$ & $(-2.88)$ & $(-1.27)$ \\
\hline \multirow[t]{2}{*}{ Year95 } & $-0.940^{*}$ & $-1.658^{* * *}$ & -0.179 \\
\hline & $(-1.92)$ & $(-4.32)$ & $(-0.44)$ \\
\hline \multirow[t]{2}{*}{ Year96 } & -0.487 & $-0.786^{* *}$ & -0.489 \\
\hline & $(-0.79)$ & $(-2.09)$ & $(-1.23)$ \\
\hline \multirow[t]{2}{*}{ Year97 } & $-0.996^{*}$ & $-1.305^{* * *}$ & -0.421 \\
\hline & $(-1.89)$ & $(-3.53)$ & $(-1.12)$ \\
\hline \multirow[t]{2}{*}{ Year98 } & -0.00629 & $-1.082^{* * *}$ & -0.330 \\
\hline & $(-0.01)$ & $(-2.99)$ & $(-0.85)$ \\
\hline \multirow[t]{2}{*}{ Year99 } & -0.427 & -0.504 & -0.409 \\
\hline & $(-0.97)$ & $(-1.23)$ & $(-1.10)$ \\
\hline \multirow[t]{2}{*}{ Year00 } & -0.489 & $-0.830^{* *}$ & -0.179 \\
\hline & $(-1.04)$ & $(-2.26)$ & $(-0.51)$ \\
\hline \multirow[t]{2}{*}{ Year01 } & 0.143 & $-1.120^{* * *}$ & -0.0915 \\
\hline & $(0.34)$ & $(-2.86)$ & $(-0.26)$ \\
\hline \multirow[t]{2}{*}{ Year02 } & 0.0585 & $-1.190^{* * *}$ & 0.0941 \\
\hline & $(0.13)$ & $(-3.28)$ & (0.33) \\
\hline \multirow[t]{2}{*}{ Year03 } & -0.130 & $-0.793^{*}$ & -0.440 \\
\hline & $(-0.29)$ & $(-1.91)$ & $(-1.45)$ \\
\hline \multirow[t]{2}{*}{ Year04 } & -0.312 & $-1.020^{* *}$ & -0.218 \\
\hline & $(-0.76)$ & $(-2.52)$ & $(-0.78)$ \\
\hline
\end{tabular}




\begin{tabular}{|c|c|c|c|}
\hline Year05 & $\begin{array}{c}-0.0920 \\
(-0.22)\end{array}$ & $\begin{array}{l}-0.382 \\
(-0.84)\end{array}$ & $\begin{array}{c}0.00258 \\
(0.01)\end{array}$ \\
\hline$E G Y$ & $\begin{array}{c}6.934^{* * *} \\
(4.33)\end{array}$ & $\begin{array}{l}1.094 \\
(1.50)\end{array}$ & $\begin{array}{c}-2.187^{* * *} \\
(-5.44)\end{array}$ \\
\hline$G M B$ & $\begin{array}{c}7.186^{* * *} \\
(5.14)\end{array}$ & $\begin{array}{l}0.645^{*} \\
(1.86)\end{array}$ & $\begin{array}{l}-0.237 \\
(-0.96)\end{array}$ \\
\hline$M L I$ & $\begin{array}{c}7.115^{* * * *} \\
(4.89)\end{array}$ & dropped & $\begin{array}{c}-0.474^{*} \\
(-1.84)\end{array}$ \\
\hline$N G A$ & $\begin{array}{c}5.209^{* * * *} \\
(4.05)\end{array}$ & $\begin{array}{c}0.412 \\
(1.09)\end{array}$ & $\begin{array}{c}-1.074^{* * *} \\
(-4.15)\end{array}$ \\
\hline$S D N$ & $\begin{array}{c}8.250^{* * * *} \\
(5.65)\end{array}$ & $\begin{array}{c}0.921^{* *} \\
(2.20)\end{array}$ & $\begin{array}{c}-0.884^{* * *} \\
(-3.86)\end{array}$ \\
\hline SEN & $\begin{array}{c}6.770^{* * *} \\
(4.57)\end{array}$ & $\begin{array}{l}-0.335 \\
(-0.73)\end{array}$ & $\begin{array}{c}-0.969^{* * *} \\
(-4.59)\end{array}$ \\
\hline$T C D$ & dropped & $\begin{array}{c}0.817^{* *} \\
(2.22)\end{array}$ & dropped \\
\hline$Z W E$ & $\begin{array}{c}4.469^{* * *} \\
(3.99)\end{array}$ & dropped & $\begin{array}{c}0.633^{* * *} \\
(2.61)\end{array}$ \\
\hline$A U T$ & $\begin{array}{c}-6.704^{* * *} \\
(-4.46)\end{array}$ & $\begin{array}{c}-2.390^{* * *} \\
(-2.79)\end{array}$ & $\begin{array}{l}-1.824 \\
(-1.19)\end{array}$ \\
\hline$B L X$ & $\begin{array}{c}-4.668^{* * *} \\
(-3.98)\end{array}$ & $\begin{array}{c}-2.079^{* * *} \\
(-7.76)\end{array}$ & $\begin{array}{l}-1.317 \\
(-1.01)\end{array}$ \\
\hline CHE & $\begin{array}{c}-2.939^{* * *} \\
(-3.61)\end{array}$ & $\begin{array}{c}-1.962^{* * *} \\
(-2.77)\end{array}$ & $\begin{array}{l}-0.597 \\
(-0.60)\end{array}$ \\
\hline$D E U$ & $\begin{array}{l}1.224^{* *} \\
(2.56)\end{array}$ & $\begin{array}{l}0.550 \\
(1.01)\end{array}$ & $\begin{array}{l}-0.151 \\
(-0.42)\end{array}$ \\
\hline$D N K$ & $\begin{array}{c}-2.528^{* * *} \\
(-3.62)\end{array}$ & $\begin{array}{l}0.757 \\
(1.35)\end{array}$ & $\begin{array}{c}1.807^{* * *} \\
(4.86)\end{array}$ \\
\hline$E S P$ & $\begin{array}{c}-2.774^{* * *} \\
(-3.64)\end{array}$ & $\begin{array}{c}1.892^{* * *} \\
(4.43)\end{array}$ & $\begin{array}{l}-0.331 \\
(-0.47)\end{array}$ \\
\hline$F I N$ & $\begin{array}{c}-7.728^{* * *} \\
(-4.10)\end{array}$ & dropped & $\begin{array}{l}-1.889 \\
(-1.00)\end{array}$ \\
\hline$G B R$ & $\begin{array}{l}-0.944 \\
(-1.55)\end{array}$ & $\begin{array}{l}-0.375 \\
(-0.73)\end{array}$ & $\begin{array}{c}-0.918^{* *} \\
(-2.30)\end{array}$ \\
\hline$I R L$ & $\begin{array}{c}-9.123^{* * *} \\
(-4.34)\end{array}$ & dropped & $\begin{array}{l}-2.763 \\
(-1.31)\end{array}$ \\
\hline ITA & $\begin{array}{l}-0.371 \\
(-0.71)\end{array}$ & $\begin{array}{l}-0.139 \\
(-0.68)\end{array}$ & $\begin{array}{l}0.304 \\
(1.01)\end{array}$ \\
\hline$N L D$ & $\begin{array}{c}-4.162^{* * *} \\
(-4.55)\end{array}$ & $\begin{array}{c}-1.325^{* * *} \\
(-5.78)\end{array}$ & $\begin{array}{l}-2.374^{* *} \\
(-2.36)\end{array}$ \\
\hline$P R T$ & dropped & $\begin{array}{l}1.262 \\
(1.12)\end{array}$ & $\begin{array}{l}-2.252 \\
(-1.16)\end{array}$ \\
\hline SWE & $\begin{array}{c}1.645 \\
(1.47)\end{array}$ & $\begin{array}{c}2.237^{* * *} \\
(4.46)\end{array}$ & $\begin{array}{c}3.230^{* * *} \\
(5.57)\end{array}$ \\
\hline Cons & $\begin{array}{c}65.10^{* * * *} \\
(3.82)\end{array}$ & $\begin{array}{l}37.30^{* * *} \\
(7.36)\end{array}$ & $\begin{array}{l}50.22^{* * *} \\
(2.25)\end{array}$ \\
\hline
\end{tabular}




\begin{tabular}{|c|c|c|c|}
\hline ln_dispersion & $\begin{array}{c}1.192^{* * *} \\
(8.03)\end{array}$ & $\begin{array}{c}-0.353^{* * *} \\
(-3.44)\end{array}$ & $\begin{array}{c}0.737^{* * *} \\
(7.44)\end{array}$ \\
\hline \multicolumn{4}{|l|}{ Outcome Eq. } \\
\hline & Trade & Trade & Trade \\
\hline \multirow[t]{2}{*}{$M R L$} & $-0.697^{*}$ & 1.034 & 0.248 \\
\hline & $(-1.78)$ & $(1.26)$ & $(0.94)$ \\
\hline \multirow[t]{2}{*}{$G D P$} & $-5.743^{* * *}$ & -1.335 & 1.088 \\
\hline & $(-4.05)$ & $(-0.65)$ & $(0.93)$ \\
\hline \multirow[t]{2}{*}{ Supply } & $0.447^{* *}$ & $0.737^{* * *}$ & $0.653^{* * *}$ \\
\hline & $(2.11)$ & $(10.47)$ & $(7.05)$ \\
\hline \multirow[t]{2}{*}{ Dist } & $4.684^{* * *}$ & $-6.768^{* * *}$ & -1.453 \\
\hline & $(2.86)$ & $(-5.55)$ & $(-0.57)$ \\
\hline \multirow[t]{2}{*}{ Dlang } & 0.472 & $0.422^{* *}$ & $-1.122^{* * *}$ \\
\hline & $(0.47)$ & $(2.41)$ & $(-4.42)$ \\
\hline \multirow{2}{*}{ Year89 } & $-2.806^{* *}$ & -0.562 & 0.912 \\
\hline & $(-2.52)$ & $(-0.75)$ & (1.27) \\
\hline \multirow[t]{2}{*}{ Year90 } & $-2.644^{* *}$ & -0.902 & 0.927 \\
\hline & $(-2.32)$ & $(-1.29)$ & (1.38) \\
\hline \multirow[t]{2}{*}{ Year91 } & $-2.115^{* *}$ & -0.525 & 0.770 \\
\hline & $(-1.99)$ & $(-0.78)$ & $(1.14)$ \\
\hline \multirow[t]{2}{*}{ Year92 } & $-1.800^{* *}$ & -0.797 & -0.0212 \\
\hline & $(-2.00)$ & $(-1.26)$ & $(-0.03)$ \\
\hline \multirow[t]{2}{*}{ Year93 } & $-1.918^{*}$ & -0.633 & 0.396 \\
\hline & $(-1.92)$ & $(-0.96)$ & $(0.62)$ \\
\hline \multirow[t]{2}{*}{ Year94 } & $-2.106^{* * *}$ & 0.0100 & 0.656 \\
\hline & $(-2.79)$ & $(0.02)$ & $(1.10)$ \\
\hline \multirow[t]{2}{*}{ Year95 } & -1.198 & -0.277 & 0.382 \\
\hline & $(-1.43)$ & $(-0.47)$ & $(0.69)$ \\
\hline \multirow[t]{2}{*}{ Year96 } & $-2.738^{* * *}$ & -0.501 & -0.0563 \\
\hline & $(-3.31)$ & $(-0.88)$ & $(-0.10)$ \\
\hline \multirow[t]{2}{*}{ Year97 } & $-2.036^{* * *}$ & -0.386 & 0.287 \\
\hline & $(-2.75)$ & $(-0.72)$ & $(0.53)$ \\
\hline \multirow[t]{2}{*}{ Year98 } & $-1.732^{* *}$ & -0.146 & -0.0376 \\
\hline & $(-2.41)$ & $(-0.26)$ & $(-0.07)$ \\
\hline \multirow[t]{2}{*}{ Year99 } & -0.0876 & -0.0803 & 0.00493 \\
\hline & $(-0.13)$ & $(-0.13)$ & $(0.01)$ \\
\hline \multirow[t]{2}{*}{ Year00 } & -0.815 & -0.317 & -0.208 \\
\hline & $(-1.32)$ & $(-0.68)$ & $(-0.44)$ \\
\hline \multirow[t]{2}{*}{ Year01 } & 0.0670 & -0.0653 & 0.434 \\
\hline & $(0.09)$ & $(-0.15)$ & $(0.87)$ \\
\hline \multirow[t]{2}{*}{ Year02 } & -0.456 & -0.0555 & -0.0551 \\
\hline & $(-0.79)$ & $(-0.14)$ & $(-0.16)$ \\
\hline \multirow[t]{2}{*}{ Year03 } & $-0.841^{*}$ & -0.194 & -0.327 \\
\hline & $(-1.75)$ & $(-0.43)$ & $(-0.98)$ \\
\hline \multirow[t]{2}{*}{ Year04 } & 0.0124 & -0.627 & -0.323 \\
\hline & $(0.02)$ & $(-1.41)$ & $(-1.00)$ \\
\hline
\end{tabular}




\begin{tabular}{|c|c|c|c|}
\hline Year05 & $\begin{array}{l}-0.344 \\
(-0.69)\end{array}$ & $\begin{array}{c}0.00931 \\
(0.02)\end{array}$ & $\begin{array}{c}-0.0782 \\
(-0.25)\end{array}$ \\
\hline$E G Y$ & $\begin{array}{c}5.357^{* * *} \\
(3.04)\end{array}$ & $\begin{array}{c}-10.25^{* * *} \\
(-6.68)\end{array}$ & $\begin{array}{l}-3.481 \\
(-1.29)\end{array}$ \\
\hline$G M B$ & $\begin{array}{c}3.547^{* * *} \\
(3.40)\end{array}$ & $\begin{array}{c}-4.980^{* * *} \\
(-5.19)\end{array}$ & $\begin{array}{l}-0.688 \\
(-0.35)\end{array}$ \\
\hline$M L I$ & $\begin{array}{c}1.602 \\
(1.58)\end{array}$ & dropped & $\begin{array}{l}-0.675 \\
(-0.29)\end{array}$ \\
\hline$N G A$ & $\begin{array}{c}2.159^{* *} \\
(2.25)\end{array}$ & $\begin{array}{c}-4.406^{* * *} \\
(-5.17)\end{array}$ & $\begin{array}{l}-1.671 \\
(-0.87)\end{array}$ \\
\hline$S D N$ & $\begin{array}{c}4.356^{* * *} \\
(3.76)\end{array}$ & $\begin{array}{c}-5.752^{* * *} \\
(-5.43)\end{array}$ & $\begin{array}{l}-1.384 \\
(-0.76)\end{array}$ \\
\hline SEN & $\begin{array}{c}2.677^{* * *} \\
(3.45)\end{array}$ & $\begin{array}{c}-5.315^{* * *} \\
(-5.72)\end{array}$ & $\begin{array}{l}-1.404 \\
(-0.70)\end{array}$ \\
\hline$T C D$ & dropped & $\begin{array}{c}-6.784^{* * *} \\
(-5.78)\end{array}$ & dropped \\
\hline$Z W E$ & $\begin{array}{l}-0.928 \\
(-1.23)\end{array}$ & dropped & $\begin{array}{c}-1.413^{* *} \\
(-1.98)\end{array}$ \\
\hline$A U T$ & $\begin{array}{c}-14.15^{* * *} \\
(-4.93)\end{array}$ & $\begin{array}{l}-5.207 \\
(-1.17)\end{array}$ & $\begin{array}{l}-0.882 \\
(-0.37)\end{array}$ \\
\hline$B L X$ & $\begin{array}{c}-8.794^{* * *} \\
(-3.57)\end{array}$ & $\begin{array}{l}-3.880 \\
(-1.13)\end{array}$ & $\begin{array}{l}-0.629 \\
(-0.31)\end{array}$ \\
\hline CHE & $\begin{array}{c}-9.679^{* * *} \\
(-5.25)\end{array}$ & $\begin{array}{l}-3.064 \\
(-1.07)\end{array}$ & $\begin{array}{l}2.888^{*} \\
(1.88)\end{array}$ \\
\hline$D E U$ & $\begin{array}{c}3.071^{* * *} \\
(4.00)\end{array}$ & $\begin{array}{l}0.335 \\
(0.33)\end{array}$ & $\begin{array}{l}-0.657 \\
(-1.09)\end{array}$ \\
\hline$D N K$ & $\begin{array}{c}-8.223^{* * *} \\
(-6.48)\end{array}$ & $\begin{array}{c}-3.531^{* * *} \\
(-4.18)\end{array}$ & $\begin{array}{l}-1.760 \\
(-1.61)\end{array}$ \\
\hline$E S P$ & $\begin{array}{c}-3.790^{* * *} \\
(-2.85)\end{array}$ & $\begin{array}{c}-10.62^{* * *} \\
(-5.21)\end{array}$ & $\begin{array}{l}-0.254 \\
(-0.22)\end{array}$ \\
\hline FIN & $\begin{array}{c}-18.17^{* * *} \\
(-5.15)\end{array}$ & dropped & $\begin{array}{l}0.629 \\
(0.22)\end{array}$ \\
\hline$G B R$ & $\begin{array}{l}-1.397 \\
(-1.08)\end{array}$ & $\begin{array}{l}-1.328 \\
(-1.10)\end{array}$ & $\begin{array}{c}1.350^{* *} \\
(2.03)\end{array}$ \\
\hline$I R L$ & $\begin{array}{c}-18.76^{* * * *} \\
(-4.75)\end{array}$ & dropped & $\begin{array}{l}-1.718 \\
(-0.51)\end{array}$ \\
\hline ITA & $\begin{array}{l}0.113 \\
(0.15)\end{array}$ & $\begin{array}{l}-0.456 \\
(-1.09)\end{array}$ & $\begin{array}{l}1.393 \\
(1.26)\end{array}$ \\
\hline$N L D$ & $\begin{array}{c}-5.496^{* * *} \\
(-2.89)\end{array}$ & $\begin{array}{l}-3.792 \\
(-1.42)\end{array}$ & $\begin{array}{l}1.481 \\
(0.94)\end{array}$ \\
\hline$P R T$ & dropped & $\begin{array}{c}-13.70^{* *} \\
(-2.57)\end{array}$ & $\begin{array}{c}0.683 \\
(0.23)\end{array}$ \\
\hline SWE & $\begin{array}{l}-2.390^{*} \\
(-1.93)\end{array}$ & $\begin{array}{l}-2.624^{* *} \\
(-2.46)\end{array}$ & $\begin{array}{c}-4.819^{* * *} \\
(-5.58)\end{array}$ \\
\hline Cons & $\begin{array}{c}116.4^{* * *} \\
(2.79)\end{array}$ & $\begin{array}{l}94.43 \\
(1.56)\end{array}$ & $\begin{array}{l}-20.68 \\
(-0.49)\end{array}$ \\
\hline
\end{tabular}




\section{Obs}

1736

1470

2156

Notes: a. The raw coefficients are reported for the inflation equations, that is, estimates should be interpreted as the effects on the probability of no-trade; $z$ statistics in parentheses; ${ }^{*} p<0.10$, ${ }^{* *} p<0.05,{ }^{* * *} p<0.01$; some country dummies are dropped because they don't export or import at all for a particular groundnut product. 


\section{Appendix 2: Derivation and decomposition of the marginal effects in HMR, ZIPPML, and ZINBPML models}

\section{Marginal effects in the HMR model}

In general, the selection equation determining firms' self-selection to export is specified as $\operatorname{Pr}(Y>0)=\Phi(X \gamma)$.

The outcome equation generating the trade flows conditional on trade taking place is specified as $E(\ln Y \mid Y>0)=\sum_{k} x_{k} \beta_{k}+\ln \{\exp [\delta(z+I M R)]-1\}+\eta I M R$,

where $\delta>0$ is a function of the shape parameter of the Pareto distribution of firms' productivity, the constant elasticity of substitution, and the estimated variance of the selection equation; ${ }^{23} z=x^{\prime} \cdot \hat{\gamma}$ is the linear prediction in the selection equation; $I M R=\phi(z) / \Phi(z)$ is the Inverse Mill's ratio as in Heckman (1979). The second term on the right hand side captures the trade effect of newly entered firms; and the third term on the right hand side corrects for the sample selection bias. Because we find no evidence of significant sample selection errors across all three products (see Table 6 on page 21), we assume $\eta=0$ thereafter.

Applying the rules of conditional expectations, we have $E(Y)=E(Y \mid Y>0) \cdot \operatorname{Pr}(Y>0)+E(Y \mid Y=0) \cdot \operatorname{Pr}(Y=0)=E(Y \mid Y>0) \cdot \operatorname{Pr}(Y>0)$.

Taking the logarithm of the above equation, and then taking the derivative with respect to an exogenous variable, $x_{k}$ for instance, we have

$$
\frac{\partial \ln E(Y)}{\partial x_{k}}=\frac{\partial \ln E(Y \mid Y>0)}{\partial x_{k}}+\frac{\partial \ln \operatorname{Pr}(Y>0)}{\partial x_{k}} \text {. }
$$

The above equation states that the overall marginal effect can be decomposed into an intensive margin $\frac{\partial \ln E(Y \mid Y>0)}{\partial x_{k}}$, that is, the intensification of existing trade flows, and an extensive margin $\frac{\partial \ln \operatorname{Pr}(Y>0)}{\partial x_{k}}$, that is, the creation of new trade partnership.

As Hoffman and Kassouf (2005) shows, $\frac{\partial \ln E(Y \mid Y>0)}{\partial x_{k}}=\frac{\partial E(\ln Y \mid Y>0)}{\partial x_{k}}$ holds under some regular conditions. ${ }^{24}$ Therefore, the intensive margin can be computed as

$$
\frac{\partial \ln E(Y \mid Y>0)}{\partial x_{k}}=\frac{\partial E(\ln Y \mid Y>0)}{\partial x_{k}}=\hat{\beta}_{k}+\frac{\exp [\hat{\delta}(z+I M R)]\left(\frac{\phi^{\prime}(z)}{\Phi(z)}-I M R^{2}+1\right) \hat{\delta}}{\exp [\hat{\delta}(z+I M R)]-1} \hat{\gamma}_{k},{ }^{25}
$$

where $\phi^{\prime}(z)=-\frac{z}{\sqrt{2 \pi}} \exp \left(-0.5 z^{2}\right)$ is the derivative of the standard normal density function. The above equation states that the intensive margin can be further decomposed into the existing exporting firms's margin and the new firms' margin.

When $\delta$ approaches 0 , the intensive margin reduces to

\footnotetext{
${ }^{23}$ Readers are referred to Equation (13) for the technical definition of $\delta$.

${ }^{24}$ Readers are referred to Appendix B of Hoffman and Kassouf (2005) for a detailed exploration of the conditions.

${ }^{25}$ We use this formula to compute the intensive margins in the sector of edible groundnut in Table 6.
} 
$\lim _{\delta \rightarrow 0} \frac{\partial \ln E(Y \mid Y>0)}{\partial x_{k}}=\hat{\beta}_{k}+\frac{\frac{\phi^{\prime}(z)}{\Phi(z)}-I M R^{2}+1}{z+I M R} \hat{\gamma}_{k} \cdot{ }^{26}$

The extensive margin $\frac{\partial \ln \operatorname{Pr}(Y>0)}{\partial x_{k}}$ can be readily computed from the estimates of the selection equations.

\section{Marginal effects in the ZIPPML/ZINBPML model}

Since the ZIPPML and the ZINBPML models share a common conditional mean, the derivations and interpretations of the marginal effects of the two models are the same.

The inflation equation is specified as

$\operatorname{Pr}($ NoTrade $)=\Phi(X \delta)$.

The outcome equation is specified as

$E(Y \mid$ Trade $)=\exp \left(\sum_{k} x_{k} \psi_{k}\right) .^{27}$

Applying the rules of conditional expectations, we have $E(Y)=E(Y \mid$ Trade $) \cdot \operatorname{Pr}($ Trade $)+E(Y \mid$ NoTrade $) \cdot \operatorname{Pr}($ NoTrade $)=E(Y \mid$ Trade $) \cdot \operatorname{Pr}($ Trade $)$.

Taking the logarithm to the above equation, and then taking the derivative with respect to an exogenous variable, $x_{k}$ for instance, we have

$\frac{\partial \ln E(Y)}{\partial x_{k}}=\frac{\partial \ln E(Y \mid \text { Trade })}{\partial x_{k}}+\frac{\partial \ln \operatorname{Pr}(\text { Trade })}{\partial x_{k}}$.

Replacing $\operatorname{Pr}($ Trade $)$ with 1- $\operatorname{Pr}($ NoTrade $)$, we have

$\frac{\partial \ln E(Y)}{\partial x_{k}}=\frac{\partial \ln E(Y \mid \text { Trade })}{\partial x_{k}}+\left[-\frac{\phi\left(x^{\prime} \hat{\delta}\right)}{1-\Phi\left(x^{\prime} \hat{\delta}\right)} \cdot \hat{\delta}_{k}\right]$

In the above equation, the first term on the right hand side can be interpreted as the intensive margin, which corresponds to $\hat{\psi}_{k}$; while the second term on the right hand side captures the extensive margin.

\footnotetext{
${ }^{26}$ We use this formula to compute the intensive margins in the sector of groundnut oil and shelled groundnuts in Table 6.

${ }^{27}$ Compared to the outcome equation in HMR, the conditional event for the outcome equation in ZIPPML/ZINBPML is that firms decide to export. However, this condition doesn't naturally imply a positive trade flow because the firms who've decided to export could suffer from a negative shock thus end up exporting 0.

Statistically, the outcome equation in ZIPPML/ZINBPML permits zero trade flows, while the outcome equation in HMR doesn't.
} 


\title{
Appendix 3: Full regression results with FAO supply series
}

\author{
Bo Xiong
}

John Beghin

(February 1st, 2011)

Table A3-1: Truncated OLS models (sectoral)

\begin{tabular}{|c|c|c|c|}
\hline OLS & $\begin{array}{c}\text { (edible) } \\
\text { ln_Trade }\end{array}$ & $\begin{array}{c}\text { (oil) } \\
\text { ln_Trade }\end{array}$ & $\begin{array}{l}\text { (shelled) } \\
\text { ln_Trade }\end{array}$ \\
\hline$M R L$ & $\begin{array}{l}-0.566 \\
(-1.53)\end{array}$ & $\begin{array}{l}0.946 \\
(0.90)\end{array}$ & $\begin{array}{l}-0.165 \\
(-0.48)\end{array}$ \\
\hline$G D P$ & $\begin{array}{c}-6.525^{* * *} \\
(-3.20)\end{array}$ & $\begin{array}{l}-4.321 \\
(-1.15)\end{array}$ & $\begin{array}{l}-0.258 \\
(-0.13)\end{array}$ \\
\hline Supply & $\begin{array}{l}-0.772^{*} \\
(-1.84)\end{array}$ & $\begin{array}{l}0.813 \\
(1.45)\end{array}$ & $\begin{array}{l}0.116 \\
(0.38)\end{array}$ \\
\hline Dist & $\begin{array}{l}0.812 \\
(0.47)\end{array}$ & $\begin{array}{c}-7.144^{* * *} \\
(-2.86)\end{array}$ & $\begin{array}{l}-1.299 \\
(-0.97)\end{array}$ \\
\hline Dlang & $\begin{array}{l}0.667 \\
(0.68)\end{array}$ & $\begin{array}{l}0.633^{*} \\
(1.96)\end{array}$ & $\begin{array}{c}-0.716^{* *} \\
(-2.05)\end{array}$ \\
\hline Year89 & $\begin{array}{l}-2.725^{* *} \\
(-2.14)\end{array}$ & $\begin{array}{c}-0.0878 \\
(-0.06)\end{array}$ & $\begin{array}{l}-0.283 \\
(-0.26)\end{array}$ \\
\hline Year90 & $\begin{array}{c}-4.046^{* * *} \\
(-3.72)\end{array}$ & $\begin{array}{l}-0.725 \\
(-0.51)\end{array}$ & $\begin{array}{l}0.371 \\
(0.35)\end{array}$ \\
\hline Year91 & $\begin{array}{c}-3.732^{* * *} \\
(-3.55)\end{array}$ & $\begin{array}{l}-0.574 \\
(-0.41)\end{array}$ & $\begin{array}{l}0.153 \\
(0.15)\end{array}$ \\
\hline Year92 & $\begin{array}{c}-2.792^{* * *} \\
(-2.85)\end{array}$ & $\begin{array}{l}-1.927 \\
(-1.46)\end{array}$ & $\begin{array}{l}-0.726 \\
(-0.70)\end{array}$ \\
\hline Year93 & $\begin{array}{c}-2.335^{* *} \\
(-2.38)\end{array}$ & $\begin{array}{l}-1.519 \\
(-1.16)\end{array}$ & $\begin{array}{l}-0.337 \\
(-0.33)\end{array}$ \\
\hline Year94 & $\begin{array}{c}-2.619^{* * *} \\
(-2.92)\end{array}$ & $\begin{array}{l}-0.181 \\
(-0.15)\end{array}$ & $\begin{array}{l}0.309 \\
(0.32)\end{array}$ \\
\hline Year95 & $\begin{array}{l}-1.014 \\
(-1.19)\end{array}$ & $\begin{array}{l}-0.311 \\
(-0.28)\end{array}$ & $\begin{array}{l}0.164 \\
(0.18)\end{array}$ \\
\hline Year96 & $\begin{array}{l}-1.786^{*} \\
(-1.88)\end{array}$ & $\begin{array}{l}-1.025 \\
(-0.93)\end{array}$ & $\begin{array}{l}-0.382 \\
(-0.44)\end{array}$ \\
\hline Year97 & $\begin{array}{l}-1.956^{* *} \\
(-2.49)\end{array}$ & $\begin{array}{l}-0.194 \\
(-0.20)\end{array}$ & $\begin{array}{l}-0.190 \\
(-0.23)\end{array}$ \\
\hline Year98 & $\begin{array}{c}-1.814^{* * *} \\
(-2.35)\end{array}$ & $\begin{array}{l}-0.144 \\
(-0.16)\end{array}$ & $\begin{array}{l}-0.144 \\
(-0.19)\end{array}$ \\
\hline Year99 & $\begin{array}{l}-0.929 \\
(-1.39)\end{array}$ & $\begin{array}{l}-0.980 \\
(-1.07)\end{array}$ & $\begin{array}{l}-0.692 \\
(-0.91)\end{array}$ \\
\hline Year00 & $\begin{array}{l}-0.623 \\
(-0.99)\end{array}$ & $\begin{array}{l}-0.703 \\
(-0.87)\end{array}$ & $\begin{array}{l}-0.661 \\
(-0.92)\end{array}$ \\
\hline
\end{tabular}




\begin{tabular}{|c|c|c|c|}
\hline Year01 & $\begin{array}{l}-0.234 \\
(-0.37)\end{array}$ & $\begin{array}{l}-0.330 \\
(-0.44)\end{array}$ & $\begin{array}{l}-0.362 \\
(-0.52)\end{array}$ \\
\hline \multirow[t]{2}{*}{ Year02 } & -0.797 & 0.202 & 0.161 \\
\hline & $(-1.17)$ & $(0.29)$ & $(0.26)$ \\
\hline \multirow[t]{2}{*}{ Year03 } & -0.211 & -0.944 & -0.864 \\
\hline & $(-0.33)$ & $(-1.26)$ & $(-1.45)$ \\
\hline \multirow[t]{2}{*}{ Year04 } & 0.00665 & $-1.828^{* * *}$ & -0.0711 \\
\hline & $(0.01)$ & $(-2.60)$ & $(-0.12)$ \\
\hline \multirow[t]{2}{*}{ Year05 } & -0.391 & -0.602 & 0.375 \\
\hline & $(-0.62)$ & $(-0.74)$ & $(0.63)$ \\
\hline \multirow[t]{2}{*}{$E G Y$} & -0.500 & $-13.20^{* * *}$ & $-3.491^{* *}$ \\
\hline & $(-0.25)$ & $(-4.09)$ & $(-2.34)$ \\
\hline \multirow[t]{2}{*}{$G M B$} & $-2.873^{*}$ & $-4.086^{*}$ & -1.689 \\
\hline & $(-1.69)$ & $(-1.93)$ & $(-1.48)$ \\
\hline \multirow[t]{2}{*}{$M L I$} & $-3.438^{*}$ & dropped & $-2.807^{* *}$ \\
\hline & $(-1.92)$ & & $(-2.21)$ \\
\hline \multirow[t]{2}{*}{$N G A$} & -0.0538 & $-7.381^{* * *}$ & $-5.275^{* * *}$ \\
\hline & $(-0.03)$ & $(-3.06)$ & $(-4.32)$ \\
\hline \multirow[t]{2}{*}{$S D N$} & 0.915 & $-6.429^{* * *}$ & $-2.167^{* *}$ \\
\hline & $(0.46)$ & $(-2.96)$ & $(-2.01)$ \\
\hline \multirow[t]{2}{*}{ SEN } & -1.800 & $-3.869^{* *}$ & $-2.525^{* *}$ \\
\hline & $(-1.14)$ & $(-2.05)$ & $(-2.27)$ \\
\hline \multirow[t]{2}{*}{$T C D$} & dropped & $-8.662^{* * *}$ & dropped \\
\hline & & $(-3.63)$ & \\
\hline \multirow[t]{2}{*}{$Z W E$} & $-1.689^{* * *}$ & dropped & $-3.278^{* * *}$ \\
\hline & $(-3.12)$ & & $(-5.19)$ \\
\hline \multirow[t]{2}{*}{$A U T$} & $-15.01^{* * *}$ & $-13.25^{*}$ & -3.146 \\
\hline & $(-3.75)$ & $(-1.66)$ & $(-0.82)$ \\
\hline \multirow[t]{2}{*}{$B L X$} & $-9.956^{* * *}$ & -9.405 & -1.101 \\
\hline & $(-2.95)$ & $(-1.49)$ & $(-0.33)$ \\
\hline \multirow[t]{2}{*}{ CHE } & $-10.18^{* * *}$ & -7.310 & 1.704 \\
\hline & $(-4.00)$ & $(-1.43)$ & $(0.70)$ \\
\hline \multirow[t]{2}{*}{$D E U$} & $3.472^{* * *}$ & 1.311 & 0.877 \\
\hline & (3.76) & $(0.84)$ & $(1.00)$ \\
\hline \multirow[t]{2}{*}{$D N K$} & $-4.649^{* * *}$ & $-4.010^{* * *}$ & -1.007 \\
\hline & $(-3.27)$ & $(-3.10)$ & $(-0.80)$ \\
\hline \multirow[t]{2}{*}{$E S P$} & $-4.679^{* * *}$ & $-13.86^{* * *}$ & -0.503 \\
\hline & $(-2.73)$ & $(-3.85)$ & $(-0.28)$ \\
\hline \multirow[t]{2}{*}{ FIN } & $-19.54^{* * *}$ & dropped & -1.017 \\
\hline & $(-3.99)$ & & $(-0.21)$ \\
\hline \multirow[t]{2}{*}{$G B R$} & -1.857 & -2.706 & $1.963^{* *}$ \\
\hline & $(-1.44)$ & $(-1.36)$ & (2.19) \\
\hline \multirow[t]{2}{*}{$I R L$} & $-19.98^{* * *}$ & dropped & -3.426 \\
\hline & $(-3.69)$ & & $(-0.64)$ \\
\hline \multirow[t]{2}{*}{$I T A$} & -0.0614 & -0.802 & $1.831^{* *}$ \\
\hline & $(-0.08)$ & $(-0.98)$ & $(2.10)$ \\
\hline
\end{tabular}




\begin{tabular}{lccc} 
NLD & $-6.716^{* * *}$ & $-8.104^{*}$ & 1.114 \\
& $(-2.61)$ & $(-1.67)$ & $(0.44)$ \\
PRT & dropped & $-21.30^{* *}$ & -1.514 \\
& & $(-2.20)$ & $(-0.31)$ \\
SWE & -0.413 & -1.444 & -1.821 \\
& $(-0.31)$ & $(-0.76)$ & $(-0.80)$ \\
Cons & $187.6^{* * *}$ & $184.5^{*}$ & 24.28 \\
& $(3.18)$ & $(1.67)$ & $(0.43)$ \\
\hline Obs & 287 & 231 & 462 \\
$R^{2}$ & 0.557 & 0.757 & 0.456 \\
\hline
\end{tabular}

Note: $t$ statistics in parentheses; ${ }^{*} p<0.10,{ }^{* *} p<0.05,{ }^{* * *} p<0.01$; some country dummies are dropped because they don't export or import at all for a particular groundnut product.

Table A3-2: Robust regression models (sectoral)

\begin{tabular}{|c|c|c|c|}
\hline Robust Reg. & $\begin{array}{l}\text { (edible) } \\
\text { ln_Trade }\end{array}$ & $\begin{array}{c}\text { (oil) } \\
\text { ln_Trade }\end{array}$ & $\begin{array}{l}\text { (shelled) } \\
\text { ln_Trade }\end{array}$ \\
\hline$M R L$ & $\begin{array}{l}-0.626^{*} \\
(-170)\end{array}$ & $\begin{array}{l}1.015 \\
(0.98)\end{array}$ & $\begin{array}{l}-0.243 \\
(-073)\end{array}$ \\
\hline$G D P$ & $\begin{array}{c}-6.473^{* * *} \\
(-3.19)\end{array}$ & $\begin{array}{l}-3.974 \\
(-1.07)\end{array}$ & $\begin{array}{l}-0.585 \\
(-0.31)\end{array}$ \\
\hline Supply & $\begin{array}{l}-0.811^{*} \\
(-1.95)\end{array}$ & $\begin{array}{l}0.751 \\
(1.36)\end{array}$ & $\begin{array}{c}0.0539 \\
(0.18)\end{array}$ \\
\hline Dist & $\begin{array}{l}0.747 \\
(0.43)\end{array}$ & $\begin{array}{c}-7.224^{* * *} \\
(-2.92)\end{array}$ & $\begin{array}{l}-1.436 \\
(-1.11)\end{array}$ \\
\hline Dlang & $\begin{array}{l}0.665 \\
(0.68)\end{array}$ & $\begin{array}{l}0.612^{*} \\
(1.92)\end{array}$ & $\begin{array}{l}-0.761^{* *} \\
(-2.26)\end{array}$ \\
\hline Year89 & $\begin{array}{c}-2.732^{* *} \\
(-2.16)\end{array}$ & $\begin{array}{c}-0.0513 \\
(-0.03)\end{array}$ & $\begin{array}{l}-0.597 \\
(-0.56)\end{array}$ \\
\hline Year90 & $\begin{array}{c}-4.057^{* * *} \\
(-3.74)\end{array}$ & $\begin{array}{l}-0.640 \\
(-0.46)\end{array}$ & $\begin{array}{c}0.00594 \\
(0.01)\end{array}$ \\
\hline Year91 & $\begin{array}{c}-3.760^{* * *} \\
(-3.59)\end{array}$ & $\begin{array}{l}-0.495 \\
(-0.36)\end{array}$ & $\begin{array}{l}-0.172 \\
(-0.17)\end{array}$ \\
\hline Year92 & $\begin{array}{c}-2.806^{* * *} \\
(-2.88)\end{array}$ & $\begin{array}{l}-1.814 \\
(-1.39)\end{array}$ & $\begin{array}{l}-1.056 \\
(-1.05)\end{array}$ \\
\hline Year93 & $\begin{array}{c}-2.351^{* *} \\
(-2.41)\end{array}$ & $\begin{array}{l}-1.335 \\
(-1.03)\end{array}$ & $\begin{array}{l}-0.578 \\
(-0.58)\end{array}$ \\
\hline Year94 & $\begin{array}{c}-2.636^{* * *} \\
(-2.95)\end{array}$ & $\begin{array}{c}-0.0980 \\
(-0.08)\end{array}$ & $\begin{array}{c}0.0442 \\
(0.05)\end{array}$ \\
\hline Year95 & $\begin{array}{l}-1.018 \\
(-1.20)\end{array}$ & $\begin{array}{l}-0.255 \\
(-0.23)\end{array}$ & $\begin{array}{c}-0.0743 \\
(-0.08)\end{array}$ \\
\hline Year96 & $\begin{array}{l}-1.738^{*} \\
(-1.84)\end{array}$ & $\begin{array}{l}-0.881 \\
(-0.81)\end{array}$ & $\begin{array}{l}-0.642 \\
(-0.77)\end{array}$ \\
\hline Year97 & $\begin{array}{c}-1.943^{* *} \\
(-2.49)\end{array}$ & $\begin{array}{l}-0.138 \\
(-0.14)\end{array}$ & $\begin{array}{l}-0.164 \\
(-0.21)\end{array}$ \\
\hline Year98 & $\begin{array}{c}-1.792^{* *} \\
(-2.33)\end{array}$ & $\begin{array}{c}-0.0835 \\
(-0.09)\end{array}$ & $\begin{array}{l}-0.334 \\
(-0.45)\end{array}$ \\
\hline Year99 & -0.926 & -0.923 & -0.908 \\
\hline
\end{tabular}




\begin{tabular}{|c|c|c|c|}
\hline & $(-1.40)$ & $(-1.02)$ & $(-1.23)$ \\
\hline \multirow[t]{2}{*}{ Year00 } & -0.529 & -0.605 & -0.837 \\
\hline & $(-0.84)$ & $(-0.76)$ & $(-1.20)$ \\
\hline \multirow[t]{2}{*}{ Year01 } & -0.132 & -0.198 & -0.529 \\
\hline & $(-0.21)$ & $(-0.27)$ & $(-0.79)$ \\
\hline \multirow[t]{2}{*}{ Year02 } & -0.810 & 0.228 & 0.0744 \\
\hline & $(-1.19)$ & (0.33) & $(0.13)$ \\
\hline \multirow[t]{2}{*}{ Year03 } & -0.234 & -0.911 & -0.881 \\
\hline & $(-0.37)$ & $(-1.23)$ & $(-1.53)$ \\
\hline \multirow[t]{2}{*}{ Year04 } & -0.0118 & $-1.768^{* *}$ & -0.165 \\
\hline & $(-0.02)$ & $(-2.54)$ & $(-0.29)$ \\
\hline \multirow[t]{2}{*}{ Year05 } & -0.410 & -0.584 & 0.293 \\
\hline & $(-0.65)$ & $(-0.73)$ & $(0.51)$ \\
\hline \multirow[t]{2}{*}{$E G Y$} & -0.482 & $-13.41^{* * *}$ & $-3.736^{* * *}$ \\
\hline & $(-0.24)$ & $(-4.20)$ & $(-2.59)$ \\
\hline \multirow[t]{2}{*}{$G M B$} & $-3.022^{*}$ & $-4.270^{* *}$ & $-1.982^{*}$ \\
\hline & $(-1.79)$ & $(-2.04)$ & $(-1.80)$ \\
\hline \multirow[t]{2}{*}{$M L I$} & $-3.533^{* *}$ & dropped & $-3.021^{* *}$ \\
\hline & $(-1.98)$ & & $(-2.46)$ \\
\hline \multirow[t]{2}{*}{$N G A$} & 0.0427 & $-7.274^{* * *}$ & $-5.243^{* * *}$ \\
\hline & $(0.03)$ & $(-3.05)$ & $(-4.44)$ \\
\hline \multirow[t]{2}{*}{$S D N$} & 0.898 & $-6.470^{* * *}$ & $-2.308^{* *}$ \\
\hline & $(0.45)$ & $(-3.01)$ & $(-2.21)$ \\
\hline \multirow[t]{2}{*}{ SEN } & -1.849 & $-3.968^{* *}$ & $-2.695^{* *}$ \\
\hline & $(-1.17)$ & $(-2.12)$ & $(-2.50)$ \\
\hline \multirow[t]{2}{*}{$T C D$} & dropped & $-8.818^{* * *}$ & dropped \\
\hline & & $(-3.73)$ & \\
\hline \multirow[t]{2}{*}{$Z W E$} & $-1.701^{* * *}$ & dropped & $-3.345^{* * *}$ \\
\hline & $(-3.16)$ & & $(-5.48)$ \\
\hline \multirow[t]{2}{*}{$A U T$} & $-14.85^{* * *}$ & -12.55 & -3.740 \\
\hline & $(-3.72)$ & $(-1.59)$ & $(-1.01)$ \\
\hline \multirow[t]{2}{*}{$B L X$} & $-9.792^{* * * *}$ & -8.811 & -1.633 \\
\hline & $(-2.91)$ & $(-1.41)$ & $(-0.51)$ \\
\hline \multirow[t]{2}{*}{ CHE } & $-10.13^{* * *}$ & -6.806 & 1.685 \\
\hline & $(-3.99)$ & $(-1.35)$ & $(0.72)$ \\
\hline \multirow[t]{2}{*}{$D E U$} & $3.502^{* * *}$ & 1.243 & 1.024 \\
\hline & (3.81) & $(0.80)$ & (1.21) \\
\hline \multirow[t]{2}{*}{$D N K$} & $-4.604^{* * *}$ & $-3.896^{* * *}$ & -0.987 \\
\hline & $(-3.25)$ & $(-3.05)$ & $(-0.81)$ \\
\hline \multirow[t]{2}{*}{$E S P$} & $-4.569^{* * *}$ & $-13.56^{* * *}$ & -0.696 \\
\hline & $(-2.68)$ & $(-3.80)$ & $(-0.41)$ \\
\hline \multirow[t]{2}{*}{ FIN } & $-19.46^{* * *}$ & dropped & -1.790 \\
\hline & $(-3.99)$ & & $(-0.39)$ \\
\hline \multirow[t]{2}{*}{$G B R$} & -1.756 & -2.532 & $1.897^{* *}$ \\
\hline & $(-1.36)$ & $(-1.29)$ & $(2.19)$ \\
\hline$I R L$ & $-19.76^{* * *}$ & dropped & -4.288 \\
\hline
\end{tabular}




\begin{tabular}{lccc} 
& $(-3.67)$ & & $(-0.83)$ \\
$I T A$ & 0.00105 & -0.768 & $1.878^{* *}$ \\
& $(0.00)$ & $(-0.95)$ & $(2.23)$ \\
$N L D$ & $-6.543^{* *}$ & -7.596 & 0.793 \\
& $(-2.55)$ & $(-1.58)$ & $(0.33)$ \\
PRT & dropped & dropped & -1.977 \\
& & & $(-0.41)$ \\
Cons & -0.429 & -1.534 & -1.543 \\
& $(-0.32)$ & $(-0.82)$ & $(-0.70)$ \\
\hline Obs & $187.1^{* * *}$ & 176.0 & 35.65 \\
& $(3.18)$ & $(1.61)$ & $(0.65)$ \\
\hline
\end{tabular}

Notes: $t$ statistics in parentheses; ${ }^{*} p<0.10,{ }^{* *} p<0.05,{ }^{* * *} p<0.01$; some country dummies are dropped because they don't export or import at all for a particular groundnut product.

Table A3-3: Truncated OLS model (pooled)

\begin{tabular}{|c|c|c|c|}
\hline OLS & $\begin{array}{l}\text { (edible) } \\
\text { ln_Trade }\end{array}$ & $\begin{array}{c}\text { (oil) } \\
\text { ln_Trade }\end{array}$ & $\begin{array}{l}\text { (shelled) } \\
\text { ln_Trade }\end{array}$ \\
\hline$M R L$ & $\begin{array}{c}-0.566^{*} \\
(-1.71)\end{array}$ & $\begin{array}{c}0.946 \\
(1.02)\end{array}$ & $\begin{array}{c}-0.165 \\
(0.12)\end{array}$ \\
\hline$G D P$ & $\begin{array}{c}-6.525^{* * *} \\
(-2.94)\end{array}$ & $\begin{array}{l}-4.321 \\
(1.59)\end{array}$ & $\begin{array}{l}-0.258 \\
(0.03)\end{array}$ \\
\hline Supply & $\begin{array}{l}-0.772^{*} \\
(-1.85)\end{array}$ & $\begin{array}{l}0.813 \\
(2.35)\end{array}$ & $\begin{array}{l}0.116 \\
(0.15)\end{array}$ \\
\hline Dist & $\begin{array}{l}0.812 \\
(0.44)\end{array}$ & $\begin{array}{c}-7.144^{* * *} \\
(12.99)\end{array}$ & $\begin{array}{c}-1.299 \\
(0.54)\end{array}$ \\
\hline Dlang & $\begin{array}{c}0.667 \\
(1.03)\end{array}$ & $\begin{array}{c}0.633^{* *} \\
(4.54)\end{array}$ & $\begin{array}{c}-0.716^{* *} \\
(4.47)\end{array}$ \\
\hline Year89 & $\begin{array}{c}-2.725^{* *} \\
(-2.38)\end{array}$ & $\begin{array}{c}-0.0878 \\
(0.00)\end{array}$ & $\begin{array}{l}-0.283 \\
(0.04)\end{array}$ \\
\hline Year90 & $\begin{array}{c}-4.046^{* * *} \\
(-3.70)\end{array}$ & $\begin{array}{l}-0.725 \\
(0.36)\end{array}$ & $\begin{array}{l}0.371 \\
(0.08)\end{array}$ \\
\hline Year91 & $\begin{array}{c}-3.732^{* * *} \\
(-3.39)\end{array}$ & $\begin{array}{l}-0.574 \\
(0.23)\end{array}$ & $\begin{array}{l}0.153 \\
(0.01)\end{array}$ \\
\hline Year92 & $\begin{array}{c}-2.792^{* * *} \\
(-2.69)\end{array}$ & $\begin{array}{c}-1.927^{*} \\
(2.78)\end{array}$ & $\begin{array}{l}-0.726 \\
(0.32)\end{array}$ \\
\hline Year93 & $\begin{array}{c}-2.335^{* *} \\
(-2.53)\end{array}$ & $\begin{array}{l}-1.519 \\
(1.87)\end{array}$ & $\begin{array}{l}-0.337 \\
(0.07)\end{array}$ \\
\hline Year94 & $\begin{array}{c}-2.619^{* * * *} \\
(-3.32)\end{array}$ & $\begin{array}{l}-0.181 \\
(0.03)\end{array}$ & $\begin{array}{l}0.309 \\
(0.07)\end{array}$ \\
\hline Year95 & $\begin{array}{l}-1.014 \\
(-1.42)\end{array}$ & $\begin{array}{l}-0.311 \\
(0.12)\end{array}$ & $\begin{array}{l}0.164 \\
(0.02)\end{array}$ \\
\hline Year96 & $\begin{array}{l}-1.786^{*} \\
(-1.98)\end{array}$ & $\begin{array}{l}-1.025 \\
(1.19)\end{array}$ & $\begin{array}{l}-0.382 \\
(0.11)\end{array}$ \\
\hline Year97 & $\begin{array}{c}-1.956^{* *} \\
(-2.81)\end{array}$ & $\begin{array}{l}-0.194 \\
(0.06)\end{array}$ & $\begin{array}{r}-0.190 \\
(0.03)\end{array}$ \\
\hline Year98 & $-1.814^{* *}$ & -0.144 & -0.144 \\
\hline
\end{tabular}




\begin{tabular}{|c|c|c|c|}
\hline & $(-2.81)$ & $(0.04)$ & $(0.02)$ \\
\hline \multirow[t]{2}{*}{ Year99 } & -0.929 & -0.980 & -0.692 \\
\hline & $(-1.46)$ & (1.85) & $(0.49)$ \\
\hline \multirow[t]{2}{*}{ Year00 } & -0.623 & -0.703 & -0.661 \\
\hline & $(-0.97)$ & $(0.84)$ & $(0.46)$ \\
\hline \multirow[t]{2}{*}{ Year01 } & -0.234 & -0.330 & -0.362 \\
\hline & $(-0.35)$ & $(0.21)$ & $(0.14)$ \\
\hline \multirow[t]{2}{*}{ Year02 } & -0.797 & 0.202 & 0.161 \\
\hline & $(-1.16)$ & $(0.15)$ & $(0.07)$ \\
\hline \multirow[t]{2}{*}{ Year03 } & -0.211 & -0.944 & -0.864 \\
\hline & $(-0.41)$ & (2.92) & (1.66) \\
\hline \multirow[t]{2}{*}{ Year04 } & 0.00665 & $-1.828^{* * *}$ & -0.0711 \\
\hline & $(0.01)$ & (8.17) & $(0.02)$ \\
\hline \multirow[t]{2}{*}{ Year05 } & -0.391 & -0.602 & 0.375 \\
\hline & $(-0.60)$ & $(0.77)$ & $(0.40)$ \\
\hline \multirow[t]{2}{*}{$E G Y$} & -0.500 & $-13.20^{* * *}$ & $-3.491^{*}$ \\
\hline & $(-0.24)$ & $(28.64)$ & (3.47) \\
\hline \multirow[t]{2}{*}{$G M B$} & -2.873 & $-4.086^{* *}$ & -1.689 \\
\hline & $(-1.39)$ & (5.34) & (1.38) \\
\hline \multirow[t]{2}{*}{$M L I$} & $-3.438^{* *}$ & dropped & $-2.807^{*}$ \\
\hline & $(-2.06)$ & & (3.46) \\
\hline \multirow[t]{2}{*}{$N G A$} & -0.0538 & $-7.381^{* * *}$ & $-5.275^{* * *}$ \\
\hline & $(-0.04)$ & (11.00) & (15.41) \\
\hline \multirow[t]{2}{*}{$S D N$} & 0.915 & $-6.429^{* * *}$ & $-2.167^{*}$ \\
\hline & $(0.52)$ & $(11.21)$ & $(2.89)$ \\
\hline \multirow[t]{2}{*}{ SEN } & -1.800 & $-3.869^{* *}$ & $-2.525^{*}$ \\
\hline & $(-1.16)$ & $(5.80)$ & (3.57) \\
\hline \multirow[t]{2}{*}{$T C D$} & $-8.662^{* * *}$ & dropped & dropped \\
\hline & $(-4.24)$ & & \\
\hline \multirow[t]{2}{*}{$Z W E$} & $-1.689^{* * *}$ & dropped & $-3.278^{* * *}$ \\
\hline & $(-3.42)$ & & (34.94) \\
\hline \multirow[t]{2}{*}{$A U T$} & $-15.01^{* * *}$ & $-13.25^{*}$ & -3.146 \\
\hline & $(-3.47)$ & (3.20) & (1.04) \\
\hline \multirow[t]{2}{*}{$B L X$} & $-9.956^{* * *}$ & -9.405 & -1.101 \\
\hline & $(-2.68)$ & $(2.70)$ & $(0.18)$ \\
\hline \multirow[t]{2}{*}{ CHE } & $-10.18^{* * *}$ & -7.310 & 1.704 \\
\hline & $(-3.69)$ & $(2.41)$ & $(0.66)$ \\
\hline \multirow[t]{2}{*}{$D E U$} & $3.472^{* * *}$ & 1.311 & 0.877 \\
\hline & (3.62) & $(0.94)$ & (1.00) \\
\hline \multirow[t]{2}{*}{$D N K$} & $-4.649^{* * *}$ & $-4.010^{* * *}$ & -1.007 \\
\hline & $(-3.01)$ & $(12.22)$ & $(0.42)$ \\
\hline \multirow[t]{2}{*}{$E S P$} & $-4.679^{* * *}$ & $-13.86^{* * *}$ & -0.503 \\
\hline & $(-2.46)$ & (17.53) & $(0.14)$ \\
\hline \multirow[t]{2}{*}{ FIN } & $-19.54^{* * *}$ & dropped & -1.017 \\
\hline & $(-3.70)$ & & $(0.07)$ \\
\hline$G B R$ & -1.857 & -2.706 & $1.963^{* * *}$ \\
\hline
\end{tabular}




\begin{tabular}{lccc} 
& $(-1.66)$ & $(2.14)$ & $(7.24)$ \\
$I R L$ & $-19.98^{* * *}$ & dropped & -3.426 \\
& $(-3.38)$ & & $(0.66)$ \\
ITA & -0.0614 & -0.802 & $1.831^{*}$ \\
& $(-0.09)$ & $(1.21)$ & $(3.63)$ \\
& $-6.716^{* * *}$ & $-8.104^{*}$ & 1.114 \\
PRT & $(-2.38)$ & $(3.21)$ & $(0.34)$ \\
& $-21.30^{* *}$ & dropped & -1.514 \\
SWE & $(-2.48)$ & & $(0.17)$ \\
& -0.413 & -1.444 & -1.821 \\
Cons & $(-0.30)$ & $(0.82)$ & $(2.27)$ \\
& $187.6^{* * *}$ & $184.5^{*}$ & 24.28 \\
\hline Obs & $(2.92)$ & $(3.40)$ & $(0.22)$ \\
\hline$R^{2}$ & & 980 &
\end{tabular}

Notes: a. The sector of edible groundnut is chosen as the baseline product in the pooled regression. The estimates reported in the columns of groundnut oil and shelled groundnuts are computed as the sums of the main effects and the effects interacting with the product dummy variables. The associated F-statistics of Wald's tests are reported in parentheses for the columns of groundnut oil and shelled groundnuts. $t$ statistics in parentheses for the column of edible groundnuts; ${ }^{*} p<0.10,{ }^{* *} p<0.05,{ }^{* * *} p<0.01$; some country dummies are dropped because they don't export or import at all for a particular groundnut product.

Table A3-4: First-stage of HMR (Probit) models (sectoral)

\begin{tabular}{lccc}
\hline Probit & $($ edible) & $($ oil) & (shelled) \\
MRL & $\ln ($ Prob of trade) & $\ln$ (Prob of trade) & $\ln$ (Prob of trade) \\
GDP & -0.179 & 0.827 & -0.0656 \\
& $(-1.19)$ & $(1.38)$ & $(-0.56)$ \\
Supply & $1.190^{* * *}$ & $1.764^{* * *}$ & 0.942 \\
& $(3.30)$ & $(4.03)$ & $(1.61)$ \\
Dist & $-0.777^{* * *}$ & $0.775^{* * *}$ & $-0.405^{* * *}$ \\
& $(-4.82)$ & $(4.36)^{* * *}$ & $(-3.63)$ \\
Dlang & $1.789^{* * *}$ & $1.889^{* * *}$ & $1.532^{* * *}$ \\
& $(4.54)$ & $(4.75)$ & $(5.40)$ \\
Dcol & -0.291 & 0.0107 & 0.107 \\
& $(-1.07)$ & $(0.05)$ & $(0.60)$ \\
Year89 & $0.877^{* * *}$ & 0.203 & $1.057^{* * *}$ \\
& $(2.86)$ & $(0.78)$ & $(4.70)$ \\
Year90 & $-1.253^{* * *}$ & $2.431^{* * *}$ & 0.276 \\
& $(-3.37)$ & $(5.88)$ & $(0.76)$ \\
Year91 & $-0.651^{* *}$ & $2.005^{* * *}$ & -0.109 \\
& $(-1.99)$ & $(4.98)$ & $(-0.31)$ \\
Year92 & $-0.544^{*}$ & $1.604^{* * *}$ & -0.103 \\
& $(-1.72)$ & $(3.93)$ & $(-0.30)$ \\
Year93 & $-0.735^{* *}$ & $1.507^{* * *}$ & -0.347 \\
& $(-2.32)$ & $(3.62)$ & $(-0.99)$ \\
& -0.443 & $1.287^{* * *}$ & -0.291 \\
& $(-1.47)$ & $(3.07)$ & $(-0.83)$
\end{tabular}




\begin{tabular}{|c|c|c|c|}
\hline Year94 & $\begin{array}{l}-0.138 \\
(-0.49)\end{array}$ & $\begin{array}{c}1.613^{* * *} \\
(4.06)\end{array}$ & $\begin{array}{l}0.470 \\
(1.45)\end{array}$ \\
\hline \multirow[t]{2}{*}{ Year95 } & -0.187 & $1.914^{* * *}$ & 0.274 \\
\hline & $(-0.67)$ & (4.97) & $(0.87)$ \\
\hline \multirow[t]{2}{*}{ Year96 } & $-0.703^{* *}$ & $1.181^{* * *}$ & 0.389 \\
\hline & $(-2.32)$ & (2.95) & $(1.28)$ \\
\hline \multirow[t]{2}{*}{ Year97 } & -0.00813 & $1.650^{* * *}$ & $0.479^{*}$ \\
\hline & $(-0.03)$ & (4.39) & (1.65) \\
\hline \multirow[t]{2}{*}{ Year98 } & -0.283 & $1.395^{* * *}$ & $0.483^{*}$ \\
\hline & $(-1.02)$ & (3.71) & (1.75) \\
\hline \multirow[t]{2}{*}{ Year99 } & 0.264 & 0.499 & 0.134 \\
\hline & (1.06) & (1.23) & $(0.49)$ \\
\hline \multirow[t]{2}{*}{ Year00 } & 0.177 & $0.790^{* *}$ & 0.267 \\
\hline & $(0.71)$ & (2.03) & (1.02) \\
\hline \multirow[t]{2}{*}{ Year01 } & 0.101 & $1.067^{* * *}$ & 0.356 \\
\hline & $(0.40)$ & $(2.86)$ & $(1.40)$ \\
\hline \multirow[t]{2}{*}{ Year02 } & -0.0568 & $1.146^{* * *}$ & 0.124 \\
\hline & $(-0.22)$ & $(3.10)$ & $(0.53)$ \\
\hline \multirow[t]{2}{*}{ Year03 } & -0.118 & 0.562 & 0.126 \\
\hline & $(-0.46)$ & $(1.46)$ & $(0.54)$ \\
\hline \multirow[t]{2}{*}{ Year04 } & 0.217 & $0.770^{* *}$ & 0.0895 \\
\hline & $(0.90)$ & $(2.07)$ & $(0.39)$ \\
\hline \multirow[t]{2}{*}{ Year05 } & -0.166 & 0.0132 & -0.0824 \\
\hline & $(-0.65)$ & $(0.03)$ & $(-0.35)$ \\
\hline \multirow[t]{2}{*}{$E G Y$} & $0.966^{* *}$ & $0.941^{*}$ & $2.169^{* * *}$ \\
\hline & $(2.53)$ & (1.67) & (7.83) \\
\hline \multirow[t]{2}{*}{$G M B$} & $-2.293^{* * *}$ & $2.611^{* * *}$ & -0.134 \\
\hline & $(-4.57)$ & (5.94) & $(-0.42)$ \\
\hline \multirow[t]{2}{*}{$M L I$} & $-1.867^{* * *}$ & dropped & $-0.742^{* *}$ \\
\hline & $(-4.05)$ & & $(-2.35)$ \\
\hline \multirow[t]{2}{*}{$N G A$} & $1.946^{* * *}$ & $-1.246^{* *}$ & $0.829^{* * *}$ \\
\hline & $(6.54)$ & $(-2.18)$ & $(3.40)$ \\
\hline \multirow[t]{2}{*}{$S D N$} & $-0.859^{* *}$ & $0.723^{* *}$ & $1.226^{* * *}$ \\
\hline & $(-2.45)$ & $(2.02)$ & $(6.60)$ \\
\hline \multirow[t]{2}{*}{ SEN } & $-0.549^{*}$ & $3.163^{* * *}$ & $0.845^{* * *}$ \\
\hline & $(-1.77)$ & (10.54) & $(4.02)$ \\
\hline \multirow[t]{2}{*}{$T C D$} & dropped & 0.526 & dropped \\
\hline & & (1.48) & \\
\hline \multirow[t]{2}{*}{$Z W E$} & $-0.719^{* * *}$ & dropped & $-1.069^{* * *}$ \\
\hline & $(-4.56)$ & & $(-6.03)$ \\
\hline \multirow[t]{2}{*}{$A U T$} & $1.872^{* * *}$ & $2.801^{* *}$ & 1.256 \\
\hline & $(2.62)$ & $(2.45)$ & (1.09) \\
\hline \multirow[t]{2}{*}{$B L X$} & $1.376^{* *}$ & $2.342^{* * *}$ & 0.864 \\
\hline & $(2.28)$ & (3.15) & $(0.87)$ \\
\hline \multirow[t]{2}{*}{ CHE } & 0.708 & $2.506^{* * *}$ & 0.463 \\
\hline & (1.49) & (2.73) & (0.63) \\
\hline
\end{tabular}




\begin{tabular}{lccc}
$D E U$ & -0.347 & -0.492 & 0.0855 \\
& $(-1.29)$ & $(-0.77)$ & $(0.30)^{* * *}$ \\
$D N K$ & $-1.890^{* * *}$ & -0.971 & $-1.791^{* * *}$ \\
& $(-5.37)$ & $(-1.62)$ & $(-6.07)$ \\
$E S P$ & $1.313^{* * *}$ & -0.587 & 0.168 \\
& $(3.73)$ & $(-1.12)$ & $(0.31)$ \\
$F I N$ & $1.443^{*}$ & dropped & 1.089 \\
& $(1.66)$ & & $(0.77)$ \\
$G B R$ & 0.175 & 0.541 & $0.485^{*}$ \\
& $(0.66)$ & $(0.93)$ & $(1.66)$ \\
$I R L$ & $2.679^{* * *}$ & dropped & 1.628 \\
& $(2.80)$ & & $(1.01)$ \\
$I T A$ & $0.501^{*}$ & $0.700^{* * *}$ & -0.176 \\
& $(1.89)$ & $(3.23)$ & $(-0.70)$ \\
NLD & $1.521^{* * *}$ & $1.493^{* * *}$ & $1.778^{* *}$ \\
& $(3.19)$ & $(2.58)$ & $(2.32)$ \\
PRT & dropped & 0.594 & 1.620 \\
& & $(0.35)$ & $(1.10)$ \\
SWE & $-2.309^{* * *}$ & $-2.953^{* * *}$ & $-2.944^{* * *}$ \\
& $(-6.08)$ & $(-4.72)$ & $(-5.84)$ \\
Cons & $-40.70^{* * *}$ & $-77.35^{* * *}$ & $-36.05^{* *}$ \\
& $(-3.70)$ & $(-5.82)$ & $(-2.14)$ \\
\hline Obs & 2268 & 2212 & 2268 \\
\hline
\end{tabular}

Notes: $z$ statistics in parentheses; ${ }^{*} p<0.10,{ }^{* *} p<0.05,{ }^{* * *} p<0.01$; some country dummies are dropped because they don't export or import at all for a particular groundnut product.

Table A3-5: Second-stage of HMR (Nonlinear Least Square) models (sectoral)

\begin{tabular}{lcc}
\hline NLS & (edible) & (shelled) \\
& ln_Trade & ln_Trade \\
MRL & -0.343 & -0.103 \\
& $(-0.89)$ & $(-0.30)$ \\
GDP & $-7.173^{* * *}$ & -0.204 \\
& $(-3.19)$ & $(-0.10)$ \\
\hline Supply & 0.195 & 0.350 \\
& $(0.27)$ & $(1.01)$ \\
Dist & 0.494 & -1.965 \\
& $(0.22)$ & $(-1.27)$ \\
Dlang & 0.508 & $-1.246^{* * *}$ \\
& $(0.51)$ & $(-2.71)$ \\
Year89 & -1.404 & -0.218 \\
& $(-0.93)$ & $(-0.20)$ \\
Year90 & $-3.116^{* * *}$ & 0.620 \\
& $(-2.67)$ & $(0.58)$ \\
Year91 & $-2.995^{* * *}$ & 0.405 \\
& $(-2.73)$ & $(0.39)$ \\
Year92 & $-1.973^{*}$ & -0.326 \\
& $(-1.81)$ & $(-0.31)$
\end{tabular}




\begin{tabular}{|c|c|c|}
\hline Year93 & $\begin{array}{c}-1.801^{*} \\
(-1.78)\end{array}$ & $\begin{array}{c}0.0562 \\
(0.05)\end{array}$ \\
\hline \multirow[t]{2}{*}{ Year94 } & $-2.270^{* *}$ & 0.176 \\
\hline & $(-2.56)$ & $(0.18)$ \\
\hline \multirow[t]{2}{*}{ Year95 } & -0.588 & 0.148 \\
\hline & $(-0.69)$ & $(0.16)$ \\
\hline \multirow[t]{2}{*}{ Year96 } & -1.250 & -0.460 \\
\hline & $(-1.19)$ & $(-0.53)$ \\
\hline \multirow[t]{2}{*}{ Year97 } & $-1.774^{* *}$ & -0.330 \\
\hline & $(-2.30)$ & $(-0.39)$ \\
\hline \multirow[t]{2}{*}{ Year98 } & $-1.340^{*}$ & -0.327 \\
\hline & $(-1.70)$ & $(-0.41)$ \\
\hline \multirow[t]{2}{*}{ Year99 } & -1.052 & -0.641 \\
\hline & $(-1.53)$ & $(-0.84)$ \\
\hline \multirow[t]{2}{*}{ Year00 } & -0.676 & -0.735 \\
\hline & $(-1.06)$ & $(-1.01)$ \\
\hline \multirow[t]{2}{*}{ Year01 } & -0.284 & -0.524 \\
\hline & $(-0.46)$ & $(-0.74)$ \\
\hline \multirow[t]{2}{*}{ Year02 } & -0.843 & 0.108 \\
\hline & $(-1.25)$ & (0.18) \\
\hline \multirow[t]{2}{*}{ Year03 } & -0.136 & -0.925 \\
\hline & $(-0.21)$ & $(-1.55)$ \\
\hline \multirow[t]{2}{*}{ Year04 } & -0.198 & -0.128 \\
\hline & $(-0.34)$ & $(-0.22)$ \\
\hline \multirow[t]{2}{*}{ Year05 } & -0.308 & 0.424 \\
\hline & $(-0.48)$ & $(0.71)$ \\
\hline \multirow[t]{2}{*}{$E G Y$} & -0.0745 & $-4.356^{* *}$ \\
\hline & $(-0.04)$ & $(-2.42)$ \\
\hline \multirow[t]{2}{*}{$G M B$} & 0.0997 & -1.193 \\
\hline & $(0.04)$ & $(-1.03)$ \\
\hline \multirow[t]{2}{*}{$M L I$} & -1.150 & -2.047 \\
\hline & $(-0.50)$ & $(-1.56)$ \\
\hline \multirow[t]{2}{*}{$N G A$} & -1.356 & $-5.301^{* * *}$ \\
\hline & $(-0.66)$ & $(-4.13)$ \\
\hline \multirow[t]{2}{*}{$S D N$} & 0.848 & $-2.579^{* *}$ \\
\hline & $(0.40)$ & $(-2.07)$ \\
\hline \multirow[t]{2}{*}{ SEN } & -0.690 & $-2.534^{* *}$ \\
\hline & $(-0.42)$ & $(-2.14)$ \\
\hline \multirow[t]{2}{*}{$T C D$} & 0 & 0 \\
\hline & $()$. & (.) \\
\hline \multirow[t]{2}{*}{$Z W E$} & -0.658 & $-2.301^{* * *}$ \\
\hline & $(-0.75)$ & $(-2.72)$ \\
\hline \multirow[t]{2}{*}{$A U T$} & $-15.79^{* * *}$ & -2.542 \\
\hline & $(-3.72)$ & $(-0.66)$ \\
\hline \multirow[t]{2}{*}{$B L X$} & $-10.55^{* * *}$ & -0.404 \\
\hline & $(-3.02)$ & $(-0.12)$ \\
\hline
\end{tabular}




\begin{tabular}{|c|c|c|}
\hline CHE & $\begin{array}{c}-10.11^{* * *} \\
(-3.92)\end{array}$ & $\begin{array}{l}2.318 \\
(0.95)\end{array}$ \\
\hline$D E U$ & $\begin{array}{c}3.558^{* * *} \\
(3.63)\end{array}$ & $\begin{array}{l}0.652 \\
(0.74)\end{array}$ \\
\hline$D N K$ & $\begin{array}{l}-4.565^{* *} \\
(-2.08)\end{array}$ & $\begin{array}{l}-0.107 \\
(-0.06)\end{array}$ \\
\hline$E S P$ & $\begin{array}{c}-5.466^{* * *} \\
(-2.77)\end{array}$ & $\begin{array}{c}-0.0254 \\
(-0.01)\end{array}$ \\
\hline FIN & $\begin{array}{c}-19.96^{* * *} \\
(-4.01)\end{array}$ & $\begin{array}{c}-0.0500 \\
(-0.01)\end{array}$ \\
\hline$G B R$ & $\begin{array}{l}-2.344^{*} \\
(-1.78)\end{array}$ & $\begin{array}{l}1.603^{*} \\
(1.70)\end{array}$ \\
\hline$I R L$ & $\begin{array}{c}-21.04^{* * *} \\
(-3.75)\end{array}$ & $\begin{array}{l}-2.272 \\
(-0.42)\end{array}$ \\
\hline$I T A$ & $\begin{array}{l}-0.241 \\
(-0.30)\end{array}$ & $\begin{array}{c}2.221^{* *} \\
(2.52)\end{array}$ \\
\hline$N L D$ & $\begin{array}{c}-8.423^{* * * *} \\
(-2.84)\end{array}$ & $\begin{array}{l}0.621 \\
(0.24)\end{array}$ \\
\hline$P R T$ & $\begin{array}{c}0 \\
(.)\end{array}$ & $\begin{array}{l}-0.963 \\
(-0.19)\end{array}$ \\
\hline$S W E$ & $\begin{array}{c}1.141 \\
(0.49)\end{array}$ & $\begin{array}{l}-0.517 \\
(-0.19)\end{array}$ \\
\hline Delta $^{a}$ & $\begin{array}{c}2.745^{* * *} \\
(3.17)\end{array}$ & $\begin{array}{c}0.993 \\
(1.25)\end{array}$ \\
\hline$I M R$ & $\begin{array}{c}0.512 \\
(0.50)\end{array}$ & $\begin{array}{c}0.0111 \\
(0.02)\end{array}$ \\
\hline Cons & $\begin{array}{c}195.0^{* * *} \\
(2.86)\end{array}$ & $\begin{array}{l}25.82 \\
(0.43) \\
\end{array}$ \\
\hline Obs & 287 & 462 \\
\hline
\end{tabular}

Notes: a. Delta is the parameter in the non-linear term accounting for the newly entered firms' effect. $t$ statistics in parentheses; ${ }^{*} p<0.10,{ }^{* *} p<0.05,{ }^{* * *} p<0.01$; some country dummies are dropped because they don't export or import at all for a particular groundnut product; The sector of groundnut oil fails to converge.

Table A3-6: PPML models (sectoral)

\begin{tabular}{lccc}
\hline PPML & (edible) & (oil) & (shelled) \\
Trade & Trade & Trade \\
MRL & $-0.424^{*}$ & $3.032^{* * *}$ & -0.472 \\
& $(-1.81)$ & $(3.16)$ & $(-1.55)$ \\
GDP & $2.767^{*}$ & $2.288^{* * *}$ & $7.554^{* *}$ \\
& $(1.68)$ & $(10.81)$ & $(2.48)$ \\
Supply & $-0.667^{* *}$ & $0.759^{*}$ & -0.182 \\
& $(-2.41)$ & $(1.78)$ & $(-0.75)$ \\
Dist & $5.318^{* * *}$ & -2.230 & $1.913^{* * *}$ \\
& $(6.94)$ & $(-1.32)$ & $(2.75)$ \\
Dlang & $-1.097^{*}$ & $1.045^{* *}$ & -0.385 \\
& $(-1.68)$ & $(2.56)$ & $(-0.94)$
\end{tabular}




\begin{tabular}{|c|c|c|c|}
\hline Dcol & $\begin{array}{c}1.360^{* * *} \\
(2.76)\end{array}$ & $\begin{array}{l}-0.209 \\
(-0.51)\end{array}$ & $\begin{array}{c}1.387^{* * *} \\
(5.45)\end{array}$ \\
\hline \multirow[t]{2}{*}{ Year89 } & -1.393 & $2.347^{* * *}$ & $2.993^{* *}$ \\
\hline & $(-1.51)$ & $(5.00)$ & (1.97) \\
\hline \multirow[t]{2}{*}{ Year90 } & $-2.303^{* * *}$ & $1.922^{* * *}$ & 2.470 \\
\hline & $(-2.85)$ & $(4.42)$ & (1.57) \\
\hline \multirow[t]{2}{*}{ Year91 } & $-2.080^{* *}$ & $1.819^{* * *}$ & 2.177 \\
\hline & $(-2.46)$ & (4.27) & (1.58) \\
\hline \multirow[t]{2}{*}{ Year92 } & $-1.643^{* *}$ & $1.213^{* * *}$ & 1.503 \\
\hline & $(-2.00)$ & $(2.79)$ & (1.10) \\
\hline \multirow[t]{2}{*}{ Year93 } & $-1.259^{*}$ & $1.187^{* * *}$ & 1.366 \\
\hline & $(-1.73)$ & (2.87) & (1.08) \\
\hline \multirow[t]{2}{*}{ Year94 } & $-1.443^{* *}$ & $1.394^{* * *}$ & $2.031^{*}$ \\
\hline & $(-2.19)$ & $(3.05)$ & (1.68) \\
\hline \multirow[t]{2}{*}{ Year95 } & -0.386 & $1.253^{* * *}$ & 1.763 \\
\hline & $(-0.63)$ & $(3.10)$ & (1.57) \\
\hline \multirow[t]{2}{*}{ Year96 } & -0.963 & $1.134^{* * *}$ & 1.640 \\
\hline & $(-1.58)$ & $(2.70)$ & (1.53) \\
\hline \multirow[t]{2}{*}{ Year97 } & $-0.892^{*}$ & $1.211^{* *}$ & $1.734^{*}$ \\
\hline & $(-1.66)$ & $(2.28)$ & (1.77) \\
\hline \multirow[t]{2}{*}{ Year98 } & $-0.821^{* *}$ & $1.109^{* *}$ & $1.639^{*}$ \\
\hline & $(-2.08)$ & (2.19) & (1.79) \\
\hline \multirow[t]{2}{*}{ Year99 } & -0.282 & 0.698 & 0.193 \\
\hline & $(-0.80)$ & (1.46) & $(0.24)$ \\
\hline \multirow[t]{2}{*}{ Year00 } & -0.0877 & $0.842^{*}$ & 0.660 \\
\hline & $(-0.27)$ & (1.95) & (0.89) \\
\hline \multirow[t]{2}{*}{ Year01 } & 0.233 & $1.072^{* *}$ & $1.300^{*}$ \\
\hline & $(0.59)$ & $(2.43)$ & (1.87) \\
\hline \multirow{2}{*}{ Year02 } & $-0.891^{* *}$ & 0.431 & $1.452^{* *}$ \\
\hline & $(-2.04)$ & $(0.75)$ & $(2.41)$ \\
\hline \multirow[t]{2}{*}{ Year03 } & -0.454 & -0.0693 & 0.596 \\
\hline & $(-1.39)$ & $(-0.15)$ & (1.00) \\
\hline \multirow[t]{2}{*}{ Year04 } & -0.405 & -0.495 & 0.243 \\
\hline & $(-0.97)$ & $(-1.09)$ & $(0.37)$ \\
\hline \multirow[t]{2}{*}{ Year05 } & -0.596 & -0.400 & 0.458 \\
\hline & $(-1.57)$ & $(-0.93)$ & $(0.78)$ \\
\hline \multirow[t]{2}{*}{$E G Y$} & $2.654^{* * *}$ & $-8.469^{* * *}$ & $1.482^{* * *}$ \\
\hline & (3.73) & $(-6.52)$ & (3.02) \\
\hline \multirow[t]{2}{*}{$G M B$} & -0.284 & $3.115^{* * *}$ & 0.867 \\
\hline & $(-0.20)$ & (3.43) & $(1.22)$ \\
\hline \multirow[t]{2}{*}{$M L I$} & $-3.085^{* * *}$ & dropped & $-3.444^{* * *}$ \\
\hline & $(-3.32)$ & & $(-5.05)$ \\
\hline \multirow[t]{2}{*}{$N G A$} & $2.611^{* * *}$ & -0.435 & $-2.408^{* * *}$ \\
\hline & $(4.14)$ & $(-0.35)$ & $(-5.08)$ \\
\hline \multirow[t]{2}{*}{$S D N$} & -0.556 & $2.410^{* * *}$ & $1.092^{* * *}$ \\
\hline & $(-0.63)$ & (5.29) & (2.69) \\
\hline
\end{tabular}




\begin{tabular}{|c|c|c|c|}
\hline SEN & $\begin{array}{l}-0.202 \\
(-0.28)\end{array}$ & $\begin{array}{c}4.527^{* * *} \\
(13.55)\end{array}$ & $\begin{array}{l}1.025^{*} \\
(1.91)\end{array}$ \\
\hline$T C D$ & dropped & $\begin{array}{c}-1.072^{*} \\
(-1.80)\end{array}$ & dropped \\
\hline$Z W E$ & $\begin{array}{c}-2.020^{* * *} \\
(-6.61)\end{array}$ & dropped & $\begin{array}{c}-3.343^{* * *} \\
(-6.76)\end{array}$ \\
\hline$A U T$ & $\begin{array}{l}2.876 \\
(0.90)\end{array}$ & $\begin{array}{l}2.820 \\
(1.54)\end{array}$ & $\begin{array}{l}11.65^{*} \\
(1.93)\end{array}$ \\
\hline$B L X$ & $\begin{array}{l}5.221^{*} \\
(1.96)\end{array}$ & $\begin{array}{c}1.397^{* * *} \\
(2.97)\end{array}$ & $\begin{array}{c}11.17^{* *} \\
(2.18)\end{array}$ \\
\hline CHE & $\begin{array}{l}0.887 \\
(0.44)\end{array}$ & $\begin{array}{l}3.184^{* *} \\
(2.41)\end{array}$ & $\begin{array}{c}9.822^{* *} \\
(2.53)\end{array}$ \\
\hline$D E U$ & $\begin{array}{c}0.174 \\
(0.26)\end{array}$ & $\begin{array}{l}0.534 \\
(0.57)\end{array}$ & $\begin{array}{l}-1.555 \\
(-1.30)\end{array}$ \\
\hline$D N K$ & $\begin{array}{c}-6.465^{* * *} \\
(-6.07)\end{array}$ & $\begin{array}{c}-2.869^{* * *} \\
(-2.72)\end{array}$ & $\begin{array}{c}-4.843^{* * *} \\
(-5.01)\end{array}$ \\
\hline$E S P$ & $\begin{array}{c}4.131^{* * * *} \\
(3.33)\end{array}$ & $\begin{array}{c}-7.614^{* * *} \\
(-7.62)\end{array}$ & $\begin{array}{l}3.810 \\
(1.42)\end{array}$ \\
\hline FIN & $\begin{array}{l}2.864 \\
(0.73)\end{array}$ & dropped & $\begin{array}{l}16.51^{* *} \\
(2.27)\end{array}$ \\
\hline$G B R$ & $\begin{array}{c}2.211^{* * * *} \\
(2.77)\end{array}$ & $\begin{array}{l}1.513 \\
(1.63)\end{array}$ & $\begin{array}{c}3.760^{* * *} \\
(3.02)\end{array}$ \\
\hline$I R L$ & $\begin{array}{l}5.341 \\
(1.33)\end{array}$ & dropped & $\begin{array}{l}15.84^{* *} \\
(2.06)\end{array}$ \\
\hline ITA & $\begin{array}{c}1.605^{* * *} \\
(4.24)\end{array}$ & $\begin{array}{l}0.702^{*} \\
(1.89)\end{array}$ & $\begin{array}{c}2.521^{* * * *} \\
(3.01)\end{array}$ \\
\hline$N L D$ & $\begin{array}{c}4.201^{* *} \\
(2.09)\end{array}$ & $\begin{array}{c}0.609 \\
(1.64)\end{array}$ & $\begin{array}{c}11.22^{* * *} \\
(2.82)\end{array}$ \\
\hline$P R T$ & & $\begin{array}{c}-8.223^{* * *} \\
(-4.01)\end{array}$ & $\begin{array}{c}18.42^{* *} \\
(2.42)\end{array}$ \\
\hline$S W E$ & $\begin{array}{c}-5.935^{* * *} \\
(-5.54)\end{array}$ & $\begin{array}{c}-5.452^{* * *} \\
(-5.95)\end{array}$ & $\begin{array}{c}-11.78^{* * *} \\
(-6.59)\end{array}$ \\
\hline Cons & $\begin{array}{c}-114.7^{* *} \\
(-2.42)\end{array}$ & $\begin{array}{c}-53.89^{* * *} \\
(-3.63)\end{array}$ & $\begin{array}{l}-221.5^{* *} \\
(-2.42)\end{array}$ \\
\hline Obs & 2268 & 2212 & 2268 \\
\hline
\end{tabular}

Notes: $z$ statistics in parentheses; ${ }^{*} p<0.10,{ }^{* *} p<0.05,{ }^{* * *} p<0.01$; some country dummies are dropped because they don't export or import at all for a particular groundnut product.

Table A3-7: NBPML models (sectoral)

\begin{tabular}{lccc}
\hline NBPML & (edible) & (oil) & (shelled) \\
MRL & Trade & Trade & Trade \\
& $-0.877^{* * *}$ & $2.916^{*}$ & $1.247^{* * *}$ \\
GDP & $(-2.77)$ & $(1.92)$ & $(4.01)$ \\
& $2.358^{* * *}$ & $8.832^{* * *}$ & 1.201 \\
Supply & $(6.42)$ & $(13.51)$ & $(0.67)$ \\
& $-1.003^{* * *}$ & $4.905^{* * *}$ & $-1.035^{* * *}$ \\
& $(-3.28)$ & $(12.33)$ & $(-3.51)$
\end{tabular}




\begin{tabular}{|c|c|c|c|}
\hline Dist & $\begin{array}{c}7.519^{* * *} \\
(9.85)\end{array}$ & $\begin{array}{l}12.91^{* * *} \\
(13.67)\end{array}$ & $\begin{array}{c}7.900^{* * *} \\
(8.39)\end{array}$ \\
\hline \multirow[t]{2}{*}{ Dlang } & -0.771 & -0.644 & 0.426 \\
\hline & $(-1.54)$ & $(-1.20)$ & $(0.92)$ \\
\hline \multirow[t]{2}{*}{ Dcol } & $2.267^{* * *}$ & $1.521^{* *}$ & $1.987^{* * *}$ \\
\hline & $(4.62)$ & $(2.27)$ & (3.50) \\
\hline \multirow[t]{2}{*}{ Year89 } & 0.737 & $11.60^{* * *}$ & $3.067^{* * *}$ \\
\hline & (1.18) & (13.08) & (3.12) \\
\hline \multirow[t]{2}{*}{ Year90 } & $-1.091^{*}$ & $8.256^{* * *}$ & $2.154^{* *}$ \\
\hline & $(-1.83)$ & (11.54) & (2.13) \\
\hline \multirow[t]{2}{*}{ Year91 } & 0.290 & $8.630^{* * *}$ & $2.274^{* *}$ \\
\hline & $(0.40)$ & $(9.90)$ & $(2.23)$ \\
\hline \multirow[t]{2}{*}{ Year92 } & -0.0407 & $5.502^{* * *}$ & 0.931 \\
\hline & $(-0.06)$ & (7.28) & $(0.98)$ \\
\hline \multirow[t]{2}{*}{ Year93 } & -0.521 & $7.232^{* * *}$ & -0.531 \\
\hline & $(-0.97)$ & $(7.64)$ & $(-0.60)$ \\
\hline \multirow[t]{2}{*}{ Year94 } & 0.750 & $8.929^{* * *}$ & $2.296^{* * *}$ \\
\hline & (1.19) & $(9.74)$ & (2.53) \\
\hline \multirow[t]{2}{*}{ Year95 } & 0.469 & $7.766^{* * *}$ & $1.926^{* *}$ \\
\hline & $(0.94)$ & (10.16) & $(2.24)$ \\
\hline \multirow[t]{2}{*}{ Year96 } & $-1.441^{* * *}$ & $5.434^{* * *}$ & $1.666^{* *}$ \\
\hline & $(-2.92)$ & $(6.50)$ & $(2.05)$ \\
\hline \multirow[t]{2}{*}{ Year97 } & -0.416 & $6.994^{* * *}$ & $2.128^{* * *}$ \\
\hline & $(-0.84)$ & (8.67) & $(2.90)$ \\
\hline \multirow[t]{2}{*}{ Year98 } & $-0.867^{*}$ & $5.965^{* * * *}$ & $3.760^{* * *}$ \\
\hline & $(-1.90)$ & (7.01) & (4.79) \\
\hline \multirow[t]{2}{*}{ Year99 } & $1.267^{* * *}$ & $1.664^{* *}$ & $2.360^{* * *}$ \\
\hline & $(2.72)$ & $(2.02)$ & (3.27) \\
\hline \multirow[t]{2}{*}{ Year00 } & $0.743^{*}$ & $2.424^{* *}$ & $2.846^{* * *}$ \\
\hline & (1.68) & $(2.07)$ & (3.91) \\
\hline \multirow[t]{2}{*}{ Year01 } & $0.983^{*}$ & $3.042^{* * *}$ & $3.386^{* * *}$ \\
\hline & (1.93) & $(4.48)$ & (5.07) \\
\hline \multirow[t]{2}{*}{ Year02 } & 0.874 & $4.608^{* * *}$ & 0.500 \\
\hline & $(1.36)$ & (6.71) & $(1.01)$ \\
\hline \multirow[t]{2}{*}{ Year03 } & 0.393 & $1.819^{* *}$ & -0.247 \\
\hline & $(0.87)$ & $(2.18)$ & $(-0.45)$ \\
\hline \multirow[t]{2}{*}{ Year04 } & $1.611^{* * * *}$ & 0.849 & 0.228 \\
\hline & $(2.78)$ & (1.19) & $(0.39)$ \\
\hline \multirow[t]{2}{*}{ Year05 } & -0.192 & $1.887^{*}$ & -0.0198 \\
\hline & $(-0.39)$ & $(1.90)$ & $(-0.03)$ \\
\hline \multirow[t]{2}{*}{$E G Y$} & $6.747^{* * *}$ & $7.385^{* * *}$ & $11.24^{* * *}$ \\
\hline & $(8.71)$ & (5.15) & $(10.44)$ \\
\hline \multirow[t]{2}{*}{$G M B$} & -1.279 & $17.25^{* * *}$ & $3.004^{* * *}$ \\
\hline & $(-1.34)$ & (18.03) & (2.99) \\
\hline \multirow[t]{2}{*}{$M L I$} & $-2.545^{* * *}$ & dropped & $-2.541^{* * *}$ \\
\hline & $(-3.02)$ & & $(-2.68)$ \\
\hline
\end{tabular}




\begin{tabular}{|c|c|c|c|}
\hline$N G A$ & $\begin{array}{l}5.073^{* * *} \\
(10.48)\end{array}$ & $\begin{array}{c}-7.132^{* * *} \\
(-5.37)\end{array}$ & $\begin{array}{c}3.435^{* * *} \\
(5.46)\end{array}$ \\
\hline \multirow[t]{2}{*}{$S D N$} & -0.362 & $3.077^{* * *}$ & $5.489^{* * *}$ \\
\hline & $(-0.73)$ & $(3.82)$ & $(10.05)$ \\
\hline \multirow[t]{2}{*}{ SEN } & $1.402^{* *}$ & $12.94^{* * *}$ & $5.529^{* * *}$ \\
\hline & $(2.57)$ & (18.92) & (8.38) \\
\hline \multirow[t]{2}{*}{$T C D$} & dropped & $4.563^{* * *}$ & dropped \\
\hline & & (6.05) & \\
\hline \multirow[t]{2}{*}{$Z W E$} & $-1.870^{* * *}$ & dropped & $-3.970^{* * *}$ \\
\hline & $(-5.99)$ & & $(-8.50)$ \\
\hline \multirow[t]{2}{*}{$A U T$} & $1.812^{* * *}$ & $14.99^{* * *}$ & -3.615 \\
\hline & $(2.58)$ & $(7.54)$ & $(-1.03)$ \\
\hline \multirow[t]{2}{*}{$B L X$} & $3.509^{* * *}$ & $12.09^{* * *}$ & -4.267 \\
\hline & (6.74) & $(11.41)$ & $(-1.41)$ \\
\hline \multirow[t]{2}{*}{ CHE } & 0.0711 & $11.84^{* * *}$ & 0.789 \\
\hline & $(0.11)$ & $(6.19)$ & $(0.36)$ \\
\hline \multirow[t]{2}{*}{$D E U$} & -0.712 & $-3.035^{*}$ & $-2.511^{* * *}$ \\
\hline & $(-1.36)$ & $(-1.84)$ & $(-2.69)$ \\
\hline \multirow[t]{2}{*}{$D N K$} & $-6.890^{* * *}$ & $-5.336^{* * *}$ & $-8.297^{* * *}$ \\
\hline & $(-4.53)$ & $(-3.66)$ & $(-9.50)$ \\
\hline \multirow[t]{2}{*}{$E S P$} & $2.824^{* * *}$ & -0.774 & $-3.336^{* *}$ \\
\hline & $(6.44)$ & $(-0.92)$ & $(-1.99)$ \\
\hline \multirow[t]{2}{*}{ FIN } & 0.287 & dropped & -3.357 \\
\hline & $(0.34)$ & & $(-0.77)$ \\
\hline \multirow[t]{2}{*}{$G B R$} & $1.154^{* *}$ & $2.799^{* *}$ & $-1.507^{*}$ \\
\hline & $(2.43)$ & $(2.08)$ & $(-1.73)$ \\
\hline \multirow[t]{2}{*}{$I R L$} & $5.073^{* * *}$ & dropped & -4.928 \\
\hline & $(6.48)$ & & $(-1.00)$ \\
\hline \multirow[t]{2}{*}{$I T A$} & $2.220^{* * *}$ & $6.450^{* * *}$ & -1.485 \\
\hline & $(3.90)$ & $(9.92)$ & $(-1.56)$ \\
\hline \multirow[t]{2}{*}{$N L D$} & $3.385^{* * *}$ & $6.032^{* * *}$ & -0.434 \\
\hline & (7.32) & $(6.49)$ & $(-0.19)$ \\
\hline \multirow[t]{2}{*}{$P R T$} & & $9.762^{* * *}$ & -3.089 \\
\hline & & $(2.64)$ & $(-0.69)$ \\
\hline \multirow[t]{2}{*}{$S W E$} & $-7.028^{* * *}$ & $-16.21^{* * *}$ & $-13.82^{* * *}$ \\
\hline & $(-8.61)$ & $(-11.09)$ & $(-10.99)$ \\
\hline \multirow[t]{2}{*}{ Cons } & $-120.1^{* * *}$ & $-416.5^{* * *}$ & $-89.14^{*}$ \\
\hline & $(-8.23)$ & $(-19.45)$ & $(-1.70)$ \\
\hline \multirow[t]{2}{*}{ ln_dispersion } & $2.365^{* * *}$ & $3.218^{* * *}$ & $2.968^{* * *}$ \\
\hline & (28.65) & $(43.00)$ & $(56.80)$ \\
\hline Obs & 2268 & 2212 & 2268 \\
\hline
\end{tabular}

Notes: $z$ statistics in parentheses; ${ }^{*} p<0.10,{ }^{* *} p<0.05,{ }^{* * *} p<0.01$; some country dummies are dropped because they don't export or import at all for a particular groundnut product.

Table A3-8: ZIPPML models (sectoral)

\begin{tabular}{llll}
\hline ZIPPML & (edible) & (oil) \\
Inflation Eq. & &
\end{tabular}


Prob. of no-trade Prob. of no-trade Prob. of no-trade

\begin{tabular}{|c|c|c|c|}
\hline \multirow[t]{2}{*}{$M R L$} & 0.263 & $-0.825^{*}$ & 0.0533 \\
\hline & (1.55) & $(-1.88)$ & $(0.43)$ \\
\hline \multirow[t]{2}{*}{$G D P$} & 0.627 & $-1.764^{* * *}$ & -0.447 \\
\hline & $(0.41)$ & $(-10.51)$ & $(-0.58)$ \\
\hline \multirow[t]{2}{*}{ Supply } & $0.714^{* * *}$ & $-0.781^{* * *}$ & $0.400^{* * *}$ \\
\hline & $(4.05)$ & $(-6.33)$ & (3.36) \\
\hline \multirow[t]{2}{*}{ Dist } & $-2.067^{* * *}$ & $-1.942^{* * *}$ & $-1.581^{* * *}$ \\
\hline & $(-4.84)$ & $(-7.18)$ & $(-4.98)$ \\
\hline \multirow[t]{2}{*}{ Dlang } & 0.392 & -0.0317 & -0.170 \\
\hline & (1.37) & $(-0.14)$ & $(-1.05)$ \\
\hline \multirow[t]{2}{*}{ Dcol } & $-0.973^{* * *}$ & -0.190 & $-1.004^{* * *}$ \\
\hline & $(-3.65)$ & $(-0.77)$ & $(-5.14)$ \\
\hline \multirow[t]{2}{*}{ Year89 } & $1.766^{* *}$ & $-2.431^{* * * *}$ & -0.117 \\
\hline & $(2.50)$ & $(-7.12)$ & $(-0.29)$ \\
\hline \multirow[t]{2}{*}{ Year90 } & 1.015 & $-2.003^{* * *}$ & 0.253 \\
\hline & (1.50) & $(-5.91)$ & $(0.61)$ \\
\hline \multirow[t]{2}{*}{ Year91 } & 0.847 & $-1.601^{* * * *}$ & 0.236 \\
\hline & (1.33) & $(-4.78)$ & $(0.57)$ \\
\hline \multirow[t]{2}{*}{ Year92 } & $1.104^{*}$ & $-1.508^{* * *}$ & 0.467 \\
\hline & (1.91) & $(-4.30)$ & (1.14) \\
\hline \multirow[t]{2}{*}{ Year93 } & 0.920 & $-1.286^{* * *}$ & 0.425 \\
\hline & (1.60) & $(-3.85)$ & (1.12) \\
\hline \multirow[t]{2}{*}{ Year94 } & 0.407 & $-1.612^{* * *}$ & -0.340 \\
\hline & $(0.76)$ & $(-5.02)$ & $(-0.97)$ \\
\hline \multirow[t]{2}{*}{ Year95 } & 0.661 & $-1.914^{* * *}$ & -0.153 \\
\hline & (1.37) & $(-5.96)$ & $(-0.45)$ \\
\hline \multirow[t]{2}{*}{ Year96 } & $1.105^{* *}$ & $-1.179^{* * * *}$ & -0.292 \\
\hline & (2.14) & $(-3.53)$ & $(-0.87)$ \\
\hline \multirow[t]{2}{*}{ Year97 } & 0.277 & $-1.649^{* * *}$ & -0.397 \\
\hline & $(0.65)$ & $(-5.06)$ & $(-1.25)$ \\
\hline \multirow[t]{2}{*}{ Year98 } & 0.516 & $-1.393^{* * *}$ & -0.411 \\
\hline & (1.32) & $(-4.33)$ & $(-1.30)$ \\
\hline \multirow[t]{2}{*}{ Year99 } & -0.100 & -0.496 & -0.0918 \\
\hline & $(-0.29)$ & $(-1.37)$ & $(-0.31)$ \\
\hline \multirow[t]{2}{*}{ Year00 } & -0.00793 & $-0.780^{* *}$ & -0.232 \\
\hline & $(-0.03)$ & $(-2.35)$ & $(-0.81)$ \\
\hline \multirow[t]{2}{*}{ Year01 } & 0.0899 & $-1.063^{* * *}$ & -0.318 \\
\hline & $(0.33)$ & $(-3.21)$ & $(-1.16)$ \\
\hline \multirow[t]{2}{*}{ Year02 } & 0.202 & $-1.146^{* * *}$ & -0.0779 \\
\hline & $(0.66)$ & $(-3.47)$ & $(-0.34)$ \\
\hline \multirow[t]{2}{*}{ Year03 } & 0.215 & -0.559 & -0.0874 \\
\hline & (0.77) & $(-1.53)$ & $(-0.37)$ \\
\hline \multirow[t]{2}{*}{ Year04 } & -0.211 & $-0.770^{* *}$ & -0.0641 \\
\hline & $(-0.84)$ & $(-2.17)$ & $(-0.28)$ \\
\hline Year05 & 0.143 & -0.0126 & 0.101 \\
\hline
\end{tabular}




\begin{tabular}{|c|c|c|c|}
\hline & $(0.54)$ & $(-0.03)$ & $(0.44)$ \\
\hline \multirow[t]{2}{*}{$E G Y$} & $-1.225^{* * *}$ & $-1.125^{* *}$ & $-2.277^{* * *}$ \\
\hline & $(-3.35)$ & $(-2.29)$ & $(-6.85)$ \\
\hline \multirow[t]{2}{*}{$G M B$} & $2.044^{* * *}$ & $-2.649^{* * *}$ & 0.0938 \\
\hline & (3.66) & $(-9.08)$ & $(0.27)$ \\
\hline \multirow[t]{2}{*}{$M L I$} & $1.423^{* * *}$ & dropped & $0.680^{* *}$ \\
\hline & (2.68) & & (2.04) \\
\hline \multirow[t]{2}{*}{$N G A$} & $-2.100^{* * *}$ & $1.238^{* * *}$ & $-0.873^{* * *}$ \\
\hline & $(-8.64)$ & (3.05) & $(-4.15)$ \\
\hline \multirow[t]{2}{*}{$S D N$} & $0.872^{* *}$ & $-0.756^{* * *}$ & $-1.261^{* * *}$ \\
\hline & $(2.51)$ & $(-3.47)$ & $(-7.98)$ \\
\hline \multirow[t]{2}{*}{ SEN } & 0.214 & $-3.173^{* * *}$ & $-0.873^{* * *}$ \\
\hline & $(0.69)$ & $(-16.76)$ & $(-4.39)$ \\
\hline \multirow[t]{2}{*}{$T C D$} & dropped & $-0.556^{* *}$ & dropped \\
\hline & & $(-2.50)$ & \\
\hline \multirow[t]{2}{*}{$Z W E$} & $0.630^{* * *}$ & dropped & $1.081^{* * *}$ \\
\hline & $(4.05)$ & & $(6.24)$ \\
\hline \multirow[t]{2}{*}{$A U T$} & 1.050 & $-2.809^{* * *}$ & -0.302 \\
\hline & $(0.35)$ & $(-4.44)$ & $(-0.20)$ \\
\hline \multirow[t]{2}{*}{$B L X$} & 1.594 & $-2.344^{* * *}$ & -0.00766 \\
\hline & $(0.63)$ & $(-7.29)$ & $(-0.01)$ \\
\hline \multirow[t]{2}{*}{ CHE } & 1.106 & $-2.507^{* * *}$ & 0.141 \\
\hline & $(0.58)$ & $(-5.04)$ & $(0.15)$ \\
\hline \multirow[t]{2}{*}{$D E U$} & -0.301 & 0.491 & -0.259 \\
\hline & $(-0.51)$ & (1.00) & $(-0.79)$ \\
\hline \multirow[t]{2}{*}{$D N K$} & $-1.674^{* *}$ & $0.966^{*}$ & $1.864^{* * *}$ \\
\hline & $(-2.35)$ & (1.96) & $(5.84)$ \\
\hline \multirow[t]{2}{*}{$E S P$} & 0.120 & 0.469 & 0.265 \\
\hline & $(0.09)$ & $(1.26)$ & $(0.40)$ \\
\hline \multirow[t]{2}{*}{$F I N$} & 2.442 & dropped & 0.118 \\
\hline & $(0.67)$ & & $(0.06)$ \\
\hline \multirow[t]{2}{*}{$G B R$} & 0.557 & -0.547 & -0.280 \\
\hline & $(0.90)$ & $(-1.37)$ & $(-0.78)$ \\
\hline \multirow[t]{2}{*}{$I R L$} & 1.539 & dropped & -0.440 \\
\hline & $(0.40)$ & & $(-0.22)$ \\
\hline \multirow[t]{2}{*}{$I T A$} & -0.288 & $-0.710^{* * *}$ & 0.274 \\
\hline & $(-0.76)$ & $(-3.77)$ & (1.08) \\
\hline \multirow[t]{2}{*}{$N L D$} & 0.768 & $-1.502^{* * *}$ & -1.132 \\
\hline & $(0.40)$ & $(-5.80)$ & $(-1.15)$ \\
\hline \multirow[t]{2}{*}{$P R T$} & dropped & -0.666 & -0.382 \\
\hline & & $(-0.61)$ & $(-0.20)$ \\
\hline \multirow[t]{2}{*}{$S W E$} & 0.965 & $2.948^{* * *}$ & $2.750^{* * *}$ \\
\hline & (1.07) & (5.93) & $(5.10)$ \\
\hline \multirow[t]{2}{*}{ Cons } & -7.129 & $77.88^{* * *}$ & 22.69 \\
\hline & $(-0.16)$ & (12.99) & (1.04) \\
\hline
\end{tabular}

Outcome Eq. 


\begin{tabular}{|c|c|c|c|}
\hline & Trade & Trade & Trade \\
\hline \multirow[t]{2}{*}{$M R L$} & -0.360 & $2.097^{* *}$ & $-0.738^{* *}$ \\
\hline & $(-1.63)$ & $(2.32)$ & $(-2.41)$ \\
\hline \multirow[t]{2}{*}{$G D P$} & $3.225^{*}$ & -1.100 & $4.079^{*}$ \\
\hline & $(1.80)$ & $(-0.51)$ & (1.88) \\
\hline \multirow[t]{2}{*}{ Supply } & $-0.805^{* * *}$ & 0.543 & 0.195 \\
\hline & $(-2.89)$ & (1.04) & $(0.86)$ \\
\hline \multirow[t]{2}{*}{ Dist } & -1.062 & $-5.535^{* * *}$ & $-7.127^{* *}$ \\
\hline & $(-0.71)$ & $(-3.37)$ & $(-2.40)$ \\
\hline \multirow[t]{2}{*}{ Dlang } & 0.00292 & $0.619^{* *}$ & -0.210 \\
\hline & $(0.01)$ & $(2.49)$ & $(-0.72)$ \\
\hline \multirow[t]{2}{*}{ Year89 } & -1.235 & 0.999 & 1.364 \\
\hline & $(-1.40)$ & (1.16) & (1.30) \\
\hline \multirow[t]{2}{*}{ Year90 } & $-2.063^{* *}$ & 0.742 & 1.239 \\
\hline & $(-2.52)$ & $(0.95)$ & (1.16) \\
\hline \multirow[t]{2}{*}{ Year91 } & $-1.860^{* *}$ & 0.723 & 0.962 \\
\hline & $(-2.17)$ & (0.97) & (1.01) \\
\hline \multirow[t]{2}{*}{ Year92 } & -1.310 & 0.148 & 0.449 \\
\hline & $(-1.59)$ & $(0.21)$ & $(0.47)$ \\
\hline \multirow[t]{2}{*}{ Year93 } & -0.700 & 0.168 & 0.518 \\
\hline & $(-0.93)$ & $(0.24)$ & $(0.56)$ \\
\hline \multirow[t]{2}{*}{ Year94 } & $-1.198^{*}$ & 0.370 & 0.769 \\
\hline & $(-1.76)$ & (0.53) & $(0.83)$ \\
\hline \multirow[t]{2}{*}{ Year95 } & -0.238 & 0.324 & 0.522 \\
\hline & $(-0.36)$ & $(0.53)$ & $(0.61)$ \\
\hline \multirow[t]{2}{*}{ Year96 } & -0.542 & 0.257 & 0.433 \\
\hline & $(-0.87)$ & $(0.43)$ & $(0.54)$ \\
\hline \multirow[t]{2}{*}{ Year97 } & -0.771 & 0.309 & 0.346 \\
\hline & $(-1.35)$ & $(0.48)$ & $(0.43)$ \\
\hline \multirow[t]{2}{*}{ Year98 } & $-0.744^{*}$ & 0.401 & 0.479 \\
\hline & $(-1.70)$ & (0.69) & $(0.65)$ \\
\hline \multirow[t]{2}{*}{ Year99 } & -0.365 & 0.280 & -0.670 \\
\hline & $(-0.82)$ & $(0.56)$ & $(-1.04)$ \\
\hline \multirow[t]{2}{*}{ Year00 } & -0.0770 & 0.440 & -0.153 \\
\hline & $(-0.23)$ & (0.98) & $(-0.25)$ \\
\hline \multirow[t]{2}{*}{ Year01 } & 0.365 & 0.657 & 0.459 \\
\hline & $(0.85)$ & (1.45) & $(0.77)$ \\
\hline \multirow[t]{2}{*}{ Year02 } & $-1.009^{* *}$ & 0.166 & $1.214^{* *}$ \\
\hline & $(-2.28)$ & $(0.30)$ & $(2.28)$ \\
\hline \multirow[t]{2}{*}{ Year03 } & -0.495 & -0.264 & 0.443 \\
\hline & $(-1.44)$ & $(-0.59)$ & (0.89) \\
\hline \multirow[t]{2}{*}{ Year04 } & -0.565 & -0.690 & 0.123 \\
\hline & $(-1.62)$ & $(-1.62)$ & $(0.21)$ \\
\hline \multirow[t]{2}{*}{ Year05 } & $-0.774^{* *}$ & -0.392 & 0.613 \\
\hline & $(-1.96)$ & $(-0.99)$ & $(1.21)$ \\
\hline$E G Y$ & -2.607 & $-12.41^{* * * *}$ & $-10.12^{* * *}$ \\
\hline
\end{tabular}




\begin{tabular}{|c|c|c|c|}
\hline & $(-1.41)$ & $(-6.36)$ & $(-2.92)$ \\
\hline \multirow[t]{2}{*}{$G M B$} & $-2.470^{*}$ & $-3.433^{* *}$ & $-5.596^{* * *}$ \\
\hline & $(-1.84)$ & $(-2.40)$ & $(-2.62)$ \\
\hline \multirow[t]{2}{*}{$M L I$} & $-4.982^{* * * *}$ & dropped & $-9.133^{* * *}$ \\
\hline & $(-3.47)$ & & $(-3.86)$ \\
\hline \multirow[t]{2}{*}{$N G A$} & -0.700 & $-5.104^{* *}$ & $-8.803^{* * *}$ \\
\hline & $(-0.54)$ & $(-2.32)$ & $(-4.20)$ \\
\hline \multirow[t]{2}{*}{$S D N$} & 0.730 & $-4.755^{* * *}$ & $-6.286^{* * *}$ \\
\hline & $(0.59)$ & $(-2.76)$ & $(-2.86)$ \\
\hline \multirow[t]{2}{*}{ SEN } & $-3.174^{* *}$ & $-2.715^{* *}$ & $-6.629^{* * * *}$ \\
\hline & $(-2.24)$ & $(-2.00)$ & $(-2.91)$ \\
\hline \multirow[t]{2}{*}{$T C D$} & dropped & $-6.933^{* * *}$ & dropped \\
\hline & & $(-4.11)$ & \\
\hline \multirow[t]{2}{*}{$Z W E$} & $-2.290^{* * *}$ & dropped & $-3.903^{* * *}$ \\
\hline & $(-5.85)$ & & $(-6.01)$ \\
\hline \multirow[t]{2}{*}{$A U T$} & 3.605 & -2.909 & 4.835 \\
\hline & (1.04) & $(-0.61)$ & (1.13) \\
\hline \multirow[t]{2}{*}{$B L X$} & $6.287^{* *}$ & -3.731 & 5.912 \\
\hline & $(2.13)$ & $(-1.03)$ & (1.61) \\
\hline \multirow[t]{2}{*}{ CHE } & 1.424 & -1.606 & $5.903^{* *}$ \\
\hline & $(0.64)$ & $(-0.53)$ & $(2.24)$ \\
\hline \multirow[t]{2}{*}{$D E U$} & 0.0779 & 1.218 & -0.661 \\
\hline & $(0.11)$ & (1.14) & $(-0.75)$ \\
\hline \multirow[t]{2}{*}{$D N K$} & $-6.735^{* * *}$ & $-2.559^{* *}$ & -1.711 \\
\hline & $(-5.35)$ & $(-2.41)$ & $(-1.55)$ \\
\hline \multirow[t]{2}{*}{$E S P$} & $3.938^{* * *}$ & $-10.21^{* * *}$ & 1.703 \\
\hline & (2.91) & $(-4.72)$ & $(0.85)$ \\
\hline \multirow[t]{2}{*}{ FIN } & 5.179 & dropped & $9.820^{*}$ \\
\hline & $(1.21)$ & & (1.87) \\
\hline \multirow[t]{2}{*}{$G B R$} & $2.739^{* * *}$ & -0.549 & $3.081^{* * *}$ \\
\hline & (3.27) & $(-0.41)$ & (3.25) \\
\hline \multirow[t]{2}{*}{$I R L$} & 6.209 & dropped & 7.495 \\
\hline & $(1.43)$ & & (1.36) \\
\hline \multirow[t]{2}{*}{ ITA } & $1.040^{* *}$ & -0.208 & 1.010 \\
\hline & (2.33) & $(-0.46)$ & (1.09) \\
\hline \multirow[t]{2}{*}{$N L D$} & $6.148^{* * *}$ & -3.408 & $7.364^{* * *}$ \\
\hline & $(2.76)$ & $(-1.21)$ & (2.58) \\
\hline \multirow[t]{2}{*}{$P R T$} & dropped & $-13.88^{* *}$ & 9.248 \\
\hline & & $(-2.50)$ & (1.62) \\
\hline \multirow[t]{2}{*}{$S W E$} & $-4.622^{* * *}$ & $-2.419^{* *}$ & $-3.776^{* * *}$ \\
\hline & $(-4.08)$ & $(-2.07)$ & $(-3.01)$ \\
\hline \multirow[t]{2}{*}{ Cons } & -67.77 & 80.22 & -43.39 \\
\hline & $(-1.33)$ & (1.27) & $(-0.64)$ \\
\hline Obs & 2268 & 2212 & 2268 \\
\hline
\end{tabular}

Notes: a. The raw coefficients are reported for the inflation equations, that is, estimates should be interpreted as the effects on the probability of no-trade; $z$ statistics in parentheses; ${ }^{*} p<0.10,{ }^{* *} p<0.05$, ${ }^{* * *} p<0.01$; some country dummies are dropped because they don't export or import at all for a 
particular groundnut product.

Table A3-9: ZINBPML models (sectoral)

\begin{tabular}{|c|c|c|c|}
\hline $\begin{array}{l}\text { ZINBPML } \\
\text { Inflation Eq. }^{\text {a }}\end{array}$ & (edible) & (oil) & (shelled) \\
\hline \multirow{3}{*}{$M R L$} & Prob. of no-trade & Prob. of no-trade & Prob. of no-trade \\
\hline & 0.329 & $-0.818^{*}$ & 0.0731 \\
\hline & $(1.20)$ & $(-1.85)$ & $(0.49)$ \\
\hline \multirow[t]{2}{*}{$G D P$} & $-2.567^{* *}$ & $-1.771^{* * *}$ & -0.761 \\
\hline & $(-2.36)$ & $(-10.43)$ & $(-0.87)$ \\
\hline \multirow[t]{2}{*}{ Supply } & $0.964^{* * *}$ & $-0.787^{* * *}$ & $0.447^{* * *}$ \\
\hline & $(3.56)$ & $(-6.32)$ & (3.07) \\
\hline \multirow[t]{2}{*}{ Dist } & $-2.567^{* * *}$ & $-1.981^{* * *}$ & $-1.919^{* * *}$ \\
\hline & $(-3.67)$ & $(-7.22)$ & $(-5.02)$ \\
\hline \multirow[t]{2}{*}{ Dlang } & 0.610 & -0.0425 & $-0.451^{* *}$ \\
\hline & $(0.98)$ & $(-0.19)$ & $(-2.16)$ \\
\hline \multirow[t]{2}{*}{ Dcol } & $-1.118^{* * *}$ & -0.179 & $-1.121^{* * *}$ \\
\hline & $(-3.24)$ & $(-0.73)$ & $(-4.84)$ \\
\hline \multirow[t]{2}{*}{ Year89 } & 0.506 & $-2.434^{* * *}$ & -0.317 \\
\hline & $(0.56)$ & $(-7.12)$ & $(-0.65)$ \\
\hline \multirow[t]{2}{*}{ Year90 } & 0.00263 & $-2.005^{* * *}$ & 0.0553 \\
\hline & $(0.00)$ & $(-5.91)$ & $(0.11)$ \\
\hline \multirow[t]{2}{*}{ Year91 } & -0.161 & $-1.602^{* * *}$ & 0.0387 \\
\hline & $(-0.24)$ & $(-4.79)$ & $(0.08)$ \\
\hline \multirow[t]{2}{*}{ Year92 } & 0.353 & $-1.516^{* * *}$ & 0.404 \\
\hline & $(0.55)$ & $(-4.31)$ & $(0.83)$ \\
\hline \multirow[t]{2}{*}{ Year93 } & 0.00928 & $-1.289^{* * *}$ & 0.459 \\
\hline & $(0.02)$ & $(-3.85)$ & $(1.02)$ \\
\hline \multirow[t]{2}{*}{ Year94 } & -0.798 & $-1.609^{* * *}$ & -0.437 \\
\hline & $(-1.23)$ & $(-5.02)$ & $(-1.05)$ \\
\hline \multirow[t]{2}{*}{ Year95 } & -0.159 & $-1.915^{* * *}$ & -0.269 \\
\hline & $(-0.27)$ & $(-5.96)$ & $(-0.66)$ \\
\hline \multirow[t]{2}{*}{ Year96 } & 0.235 & $-1.182^{* * *}$ & -0.417 \\
\hline & $(0.36)$ & $(-3.53)$ & $(-1.05)$ \\
\hline \multirow[t]{2}{*}{ Year97 } & -0.764 & $-1.650^{* * *}$ & -0.549 \\
\hline & $(-1.44)$ & $(-5.05)$ & $(-1.50)$ \\
\hline \multirow[t]{2}{*}{ Year98 } & -0.312 & $-1.391^{* * *}$ & $-0.652^{*}$ \\
\hline & $(-0.71)$ & $(-4.32)$ & $(-1.72)$ \\
\hline \multirow[t]{2}{*}{ Year99 } & -0.662 & -0.497 & -0.254 \\
\hline & $(-1.28)$ & $(-1.37)$ & $(-0.73)$ \\
\hline \multirow[t]{2}{*}{ Year00 } & -0.411 & $-0.776^{* *}$ & -0.431 \\
\hline & $(-1.10)$ & $(-2.34)$ & $(-1.27)$ \\
\hline \multirow[t]{2}{*}{ Year01 } & -0.0765 & $-1.064^{* * *}$ & -0.425 \\
\hline & $(-0.22)$ & $(-3.20)$ & $(-1.25)$ \\
\hline \multirow[t]{2}{*}{ Year02 } & 0.0508 & $-1.146^{* * *}$ & -0.107 \\
\hline & $(0.11)$ & $(-3.46)$ & $(-0.39)$ \\
\hline Year03 & -0.0471 & -0.562 & -0.134 \\
\hline
\end{tabular}




\begin{tabular}{|c|c|c|c|}
\hline & $(-0.11)$ & $(-1.53)$ & $(-0.49)$ \\
\hline \multirow[t]{2}{*}{ Year04 } & -0.290 & $-0.779^{* *}$ & -0.0650 \\
\hline & $(-0.75)$ & $(-2.17)$ & $(-0.25)$ \\
\hline \multirow[t]{2}{*}{ Year05 } & 0.0195 & -0.0144 & 0.142 \\
\hline & $(0.05)$ & $(-0.04)$ & $(0.55)$ \\
\hline \multirow[t]{2}{*}{$E G Y$} & $-1.519^{* *}$ & $-1.247^{* *}$ & $-3.164^{* * *}$ \\
\hline & $(-2.47)$ & $(-2.39)$ & $(-6.90)$ \\
\hline \multirow[t]{2}{*}{$G M B$} & $2.395^{* * *}$ & $-2.682^{* * *}$ & -0.0168 \\
\hline & $(2.85)$ & $(-9.12)$ & $(-0.04)$ \\
\hline \multirow[t]{2}{*}{$M L I$} & 1.084 & dropped & 0.629 \\
\hline & $(1.05)$ & & (1.62) \\
\hline \multirow[t]{2}{*}{$N G A$} & $-2.845^{* * *}$ & $1.236^{* * *}$ & $-1.175^{* * *}$ \\
\hline & $(-5.27)$ & (3.03) & $(-4.32)$ \\
\hline \multirow[t]{2}{*}{$S D N$} & 0.907 & $-0.778^{* * *}$ & $-1.563^{* * *}$ \\
\hline & (1.44) & $(-3.54)$ & $(-8.13)$ \\
\hline \multirow[t]{2}{*}{ SEN } & -0.194 & $-3.185^{* * *}$ & $-1.113^{* * *}$ \\
\hline & $(-0.40)$ & $(-16.99)$ & $(-4.90)$ \\
\hline \multirow[t]{2}{*}{$T C D$} & dropped & $-0.591^{* * *}$ & dropped \\
\hline & & $(-2.66)$ & \\
\hline \multirow[t]{2}{*}{$Z W E$} & $0.530^{*}$ & dropped & $1.184^{* * *}$ \\
\hline & (1.79) & & (5.73) \\
\hline \multirow[t]{2}{*}{$A U T$} & $-6.074^{* *}$ & $-2.825^{* * *}$ & -1.028 \\
\hline & $(-2.56)$ & $(-4.44)$ & $(-0.60)$ \\
\hline \multirow[t]{2}{*}{$B L X$} & $-3.562^{*}$ & $-2.351^{* * *}$ & -0.590 \\
\hline & $(-1.96)$ & $(-7.22)$ & $(-0.41)$ \\
\hline \multirow[t]{2}{*}{ CHE } & $-2.946^{* *}$ & $-2.504^{* * *}$ & -0.137 \\
\hline & $(-2.08)$ & $(-5.01)$ & $(-0.12)$ \\
\hline \multirow[t]{2}{*}{$D E U$} & $0.911^{*}$ & 0.505 & -0.333 \\
\hline & $(1.76)$ & $(1.02)$ & $(-0.87)$ \\
\hline \multirow[t]{2}{*}{$D N K$} & $-1.995^{* *}$ & $0.958^{*}$ & $1.908^{* * *}$ \\
\hline & $(-2.44)$ & (1.93) & $(5.12)$ \\
\hline \multirow[t]{2}{*}{$E S P$} & $-2.644^{* * *}$ & 0.384 & -0.0363 \\
\hline & $(-2.63)$ & $(0.97)$ & $(-0.05)$ \\
\hline \multirow[t]{2}{*}{ FIN } & $-5.619^{* *}$ & & -0.662 \\
\hline & $(-2.04)$ & & $(-0.32)$ \\
\hline \multirow[t]{2}{*}{$G B R$} & -0.635 & -0.546 & $-0.686^{*}$ \\
\hline & $(-0.77)$ & $(-1.36)$ & $(-1.70)$ \\
\hline \multirow[t]{2}{*}{$I R L$} & $-7.301^{* *}$ & & -1.537 \\
\hline & $(-2.33)$ & & $(-0.66)$ \\
\hline \multirow[t]{2}{*}{$I T A$} & $-1.139^{* *}$ & $-0.713^{* * *}$ & 0.194 \\
\hline & $(-2.14)$ & $(-3.76)$ & $(0.65)$ \\
\hline \multirow[t]{2}{*}{$N L D$} & $-3.144^{* *}$ & $-1.513^{* * *}$ & -1.742 \\
\hline & $(-2.26)$ & $(-5.76)$ & $(-1.57)$ \\
\hline \multirow[t]{2}{*}{$P R T$} & dropped & -0.792 & -1.222 \\
\hline & & $(-0.71)$ & $(-0.56)$ \\
\hline$S W E$ & 1.611 & $2.948^{* * *}$ & $3.005^{* * *}$ \\
\hline
\end{tabular}




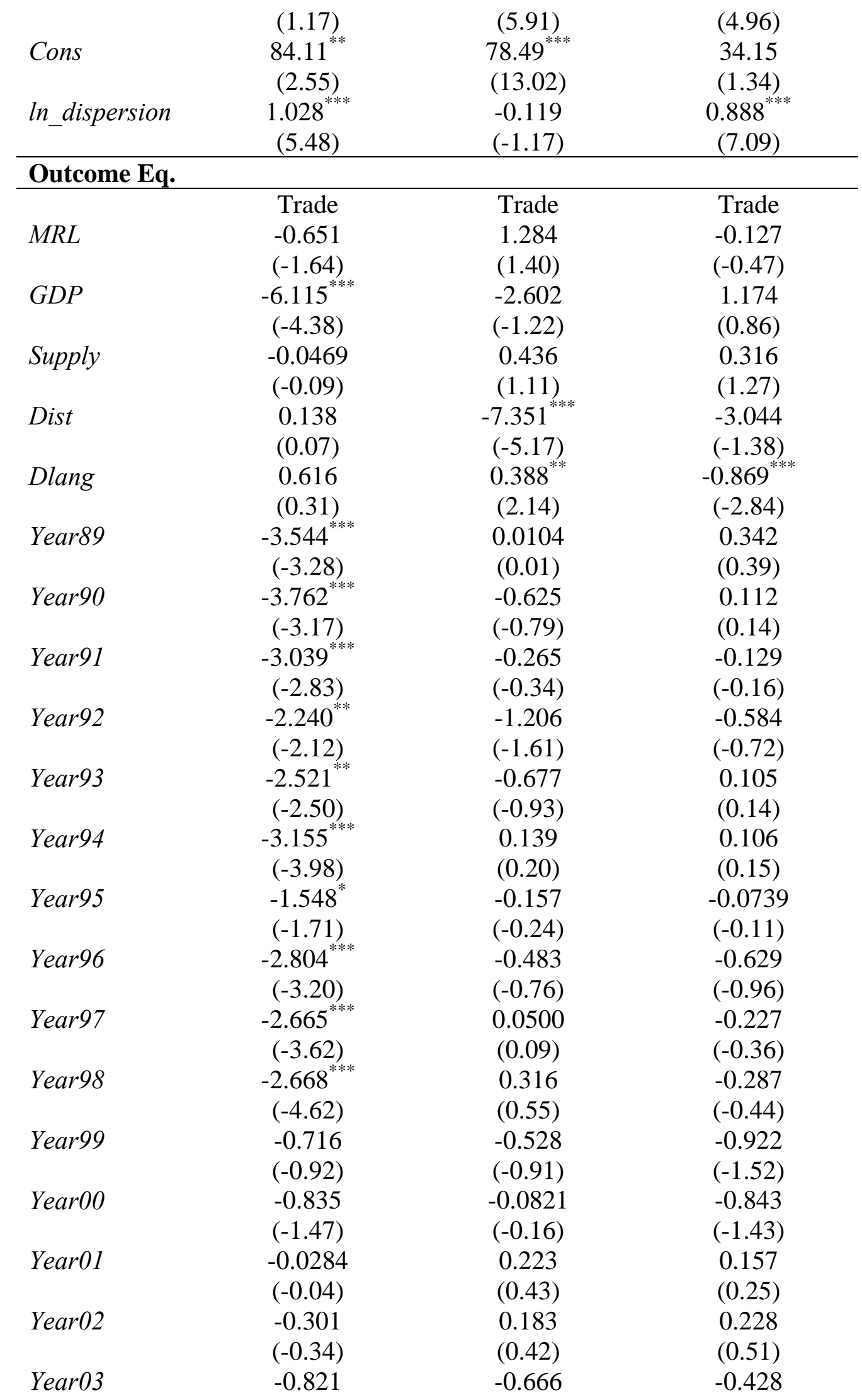




\begin{tabular}{|c|c|c|c|}
\hline & $(-1.32)$ & $(-1.37)$ & $(-0.95)$ \\
\hline \multirow[t]{2}{*}{ Year04 } & 0.0464 & $-1.143^{* *}$ & -0.402 \\
\hline & $(0.07)$ & $(-2.28)$ & $(-0.96)$ \\
\hline \multirow[t]{2}{*}{ Year05 } & -0.208 & -0.624 & 0.0590 \\
\hline & $(-0.26)$ & $(-1.37)$ & $(0.15)$ \\
\hline \multirow[t]{2}{*}{$E G Y$} & -1.246 & $-15.15^{* * *}$ & $-6.149^{* * *}$ \\
\hline & $(-0.50)$ & $(-8.49)$ & $(-2.61)$ \\
\hline \multirow[t]{2}{*}{$G M B$} & -1.746 & $-5.210^{* * *}$ & -2.182 \\
\hline & $(-1.02)$ & $(-4.57)$ & $(-1.24)$ \\
\hline \multirow[t]{2}{*}{$M L I$} & $-5.414^{* *}$ & dropped & $-5.388^{* * *}$ \\
\hline & $(-2.31)$ & & $(-2.85)$ \\
\hline \multirow[t]{2}{*}{$N G A$} & -1.709 & $-6.616^{* * *}$ & $-6.456^{* * *}$ \\
\hline & $(-0.90)$ & $(-3.86)$ & $(-3.84)$ \\
\hline \multirow[t]{2}{*}{$S D N$} & -0.0241 & $-6.732^{* * *}$ & $-3.677^{* *}$ \\
\hline & $(-0.01)$ & $(-4.61)$ & $(-2.30)$ \\
\hline \multirow[t]{2}{*}{ SEN } & $-3.451^{* *}$ & $-4.456^{* * *}$ & $-3.897^{* *}$ \\
\hline & $(-2.14)$ & $(-3.80)$ & $(-2.26)$ \\
\hline \multirow[t]{2}{*}{$T C D$} & dropped & $-9.244^{* * *}$ & dropped \\
\hline & & $(-6.58)$ & \\
\hline \multirow[t]{2}{*}{$Z W E$} & $-2.905^{* * *}$ & dropped & $-3.274^{* * *}$ \\
\hline & $(-4.45)$ & & $(-5.32)$ \\
\hline \multirow[t]{2}{*}{$A U T$} & $-15.58^{* * *}$ & -7.738 & -0.870 \\
\hline & $(-5.61)$ & $(-1.60)$ & $(-0.32)$ \\
\hline \multirow[t]{2}{*}{$B L X$} & $-9.254^{* * *}$ & $-6.088^{*}$ & 0.0497 \\
\hline & $(-3.81)$ & $(-1.70)$ & $(0.02)$ \\
\hline \multirow[t]{2}{*}{ CHE } & $-10.63^{* * *}$ & -4.383 & $3.228^{*}$ \\
\hline & $(-5.84)$ & $(-1.43)$ & (1.80) \\
\hline \multirow[t]{2}{*}{$D E U$} & $3.126^{* * *}$ & 0.994 & -0.385 \\
\hline & (4.13) & $(0.92)$ & $(-0.58)$ \\
\hline \multirow[t]{2}{*}{$D N K$} & $-8.193^{* * *}$ & $-3.488^{* * *}$ & -1.595 \\
\hline & $(-6.30)$ & $(-3.72)$ & $(-1.55)$ \\
\hline \multirow[t]{2}{*}{$E S P$} & $-4.365^{* * *}$ & $-11.99^{* * *}$ & 0.130 \\
\hline & $(-3.38)$ & $(-5.59)$ & $(0.10)$ \\
\hline \multirow[t]{2}{*}{ FIN } & $-18.52^{* * *}$ & dropped & 1.216 \\
\hline & $(-5.40)$ & & $(0.36)$ \\
\hline \multirow[t]{2}{*}{$G B R$} & -1.835 & -1.900 & $1.524^{*}$ \\
\hline & $(-0.81)$ & $(-1.45)$ & (1.93) \\
\hline \multirow[t]{2}{*}{$I R L$} & $-19.70^{* * *}$ & dropped & -1.192 \\
\hline & $(-4.37)$ & & $(-0.30)$ \\
\hline \multirow[t]{2}{*}{$I T A$} & -0.757 & -0.669 & 1.352 \\
\hline & $(-0.87)$ & $(-1.50)$ & (1.30) \\
\hline \multirow[t]{2}{*}{$N L D$} & $-6.060^{* * *}$ & $-5.544^{* *}$ & 2.166 \\
\hline & $(-3.31)$ & $(-1.99)$ & (1.18) \\
\hline \multirow[t]{2}{*}{$P R T$} & dropped & $-17.86^{* * *}$ & 2.214 \\
\hline & & $(-3.20)$ & $(0.63)$ \\
\hline SWE & -1.862 & $-1.913^{*}$ & $-3.868^{* * *}$ \\
\hline
\end{tabular}


$(-1.26)$

Cons $176.1^{*}$

(4.05) 2268

Obs
$(-1.66)$

$142.2^{* *}$

(2.21)
(-4.35)

$-0.0542$

$(-0.00)$ 2212

Notes: a. The raw coefficients are reported for the inflation equations, that is, estimates should be interpreted as the effects on the probability of no-trade; $z$ statistics in parentheses; ${ }^{*} p<0.10,{ }^{* *} p<0.05$, ${ }^{* * *} p<0.01$; some country dummies are dropped because they don't export or import at all for a particular groundnut product. 